\title{
Synthetic approaches to asymmetric phthalocyanines and their analogues
}

\author{
Victor N. Nemykin, ${ }^{\text {a }}$ Semyon V. Dudkin,, Fabienne Dumoulin, ${ }^{\text {b }}$ Catherine Hirel, \\ Ayşe Gül Gürek, ${ }^{b}$ and Vefa Ahsen*b \\ ${ }^{a}$ Department of Chemistry and Biochemistry, University of Minnesota Duluth, \\ 1039 University Drive, Duluth, MN 55812, USA \\ ${ }^{b}$ Department of Chemistry, Gebze Institute of Technology, P. O. Box 141, \\ 41400 Gebze, Kocaeli, Turkey \\ E-mail: vnemykin@d.umn.edu; $\underline{\text { ahsen@gyte.edu.tr }}$
}

\section{Dedicated to Professor Evgeny A. Luk'yanets on the occasion of his $75^{\text {th }}$ anniversary and to Professor Özer Bekaroğlu on the occasion of his $80^{\text {th }}$ anniversary}

\section{DOI: http://dx.doi.org/10.3998/ark.5550190.p008.412}

\begin{abstract}
This review summarizes synthetic strategies for the preparation of asymmetric phthalocyanines and their analogues. Cross-condensation between two phthalonitrile components, crosscondensation between one phthalonitrile and one non-nitrile component, targeted synthesis of AABB-type compounds, the subphthalocyanine ring-expansion method, as well as postmodification approaches on pre-formed symmetric and asymmetric systems, are discussed. Methodologies for targeted preparation of specific types of asymmetric phthalocyanines and their analogues are also briefly overviewed.
\end{abstract}

Keywords: Asymmetric phthalocyanines and their analogues, subphthalocyanine, substituted phthalonitriles, synthesis

\section{Table of Contents}

1. Introduction

2. Cross Condensation Between Two Different Dinitrile or 1,3-Diiminoisoindoline Components

2.1 Statistical condensation

2.2 Sterically driven cross condensation

2.3 Polymer support-based approach

2.4 Self- and cross-condensation strategy involving bis(phthalonitriles)

3. Cross Condensation Between Phthalonitrile or 1,3-Diiminoisoindoline and Non-nitrile 


\section{Components}

3.1 Cross condensation between phthalonitrile and anhydride/imide components

3.2 Cross condensation between phthalonitrile and trichloroisoindoline components

4. Targeted Synthesis of AABB-type Asymmetric Phthalocyanines from a Pre-formed AA-Type Intermediate

5. Subphthalocyanine Ring Expansion Strategy

6. Post-modification of Pre-formed Macrocycles

6.1 Cycloaddition reactions

6.2 Cross-coupling approach

6.3 Oxidative transformation strategy

6.4 Simple aromatic electrophilic or nucleophilic reactions

6.5 Peripheral substituent coordination approach

7. Miscellaneous Strategies

References

\section{Introduction}

Although the formation of a deep blue-colored phthalocyanine macrocycle was reported about hundred years ago, comprehensive investigation of this class of compound did not start until the 1930s, when Linstead and co-workers conducted extensive chemical and crystallographic studies on these fascinating macrocycles. ${ }^{1-7}$ Initially after their discovery, phthalocyanines were predominantly used as pigments and dyes in the textile and paper industries because of their chemical, photochemical, and thermal stabilities. ${ }^{8,9}$ In more recent decades the chemistry of substituted phthalocyanines has undergone tremendous growth, ${ }^{10-12}$ and, in addition to traditional applications, substituted and unsubstituted phthalocyanines have found potential applications in industrial catalysis, ${ }^{13-18}$ photosensitizers for photodynamic cancer therapy, ${ }^{16,19-26}$ markers for bioimaging, ${ }^{27,28}$ antibacterial composites, ${ }^{29-32}$ materials for ink-jet printing, ${ }^{33}$ chemical sensors, ${ }^{34-37}$ semiconductors, ${ }^{38,39}$ functional polymers and liquid crystals, ${ }^{40-43}$ light-harvesting modules for dye-sensitized solar cells and organic photovoltaics, ${ }^{44-51}$ nanotechnology, ${ }^{52-56}$ and non-linear optics. $^{57-63}$

Many of these new applications require pinpoint modification of the phthalocyanine macrocycle, which is achieved in asymmetric phthalocyanine analogues (Figure 1). For instance, in order to achieve selective surface functionalization, one needs to design an asymmetric phthalocyanine with a single anchor group, while preparation of nano-scale supramolecular assemblies demands disubstituted phthalocyanine platforms. Similarly, asymmetric-shaped phthalocyanines are desired for ideal Langmuir-Blodgett film formation, while targeting nonlinear optic properties in phthalocyanine require preparation of push-pull types of asymmetric macrocycles. ${ }^{64-69}$ In order to satisfy this demand, over the last few decades numerous research groups have made great strides in the preparation of asymmetric phthalocyanines and their analogues including triazole-, thiadiazole-, and hemiporphyrazines. ${ }^{64-74}$ 


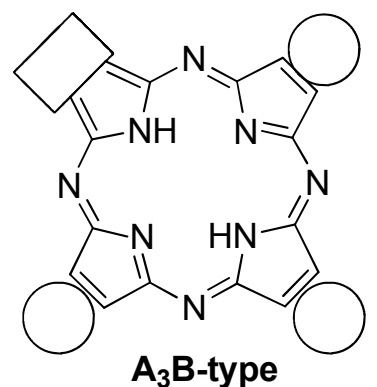

$\mathrm{A}_{3}$ B-type

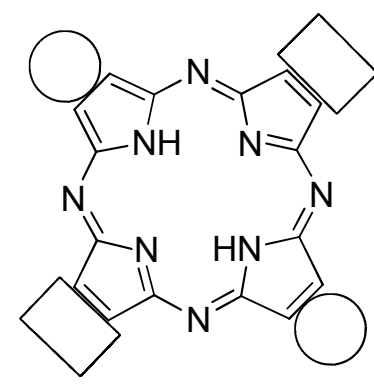

ABAB-type

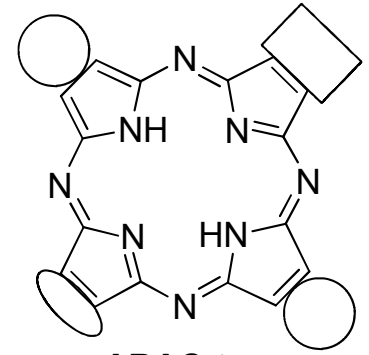

ABAC-type

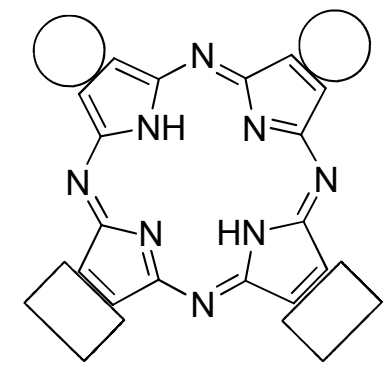

AABB-type

Figure 1. General types of asymmetric phthalocyanines and their analogues.

The chemistry of asymmetric phthalocyanines had a slow start. The first report on an asymmetric phthalocyanine analogue by Linstead and co-workers dates back to $1955,{ }^{75}$ followed by work of Luk'yanets and co-workers in $1979 .{ }^{76}$ These two initial publications were finally followed by a group of key reports between 1982 and 1995 on the preparation of asymmetric phthalocyanines and their analogues. ${ }^{77-100}$ After that time, the number of reports on the preparation of asymmetric phthalocyanines and their analogues increased almost exponentially. Moreover, during the last decade several reviews on asymmetric phthalocyanines have become available. ${ }^{67-69,101-107}$ In this review, we highlight the state-of-the-art approaches for preparation of asymmetric phthalocyanines and their analogues. Rather than focusing on the preparation of specific types of asymmetric macrocycles, we would like to provide reaction-based synthetic strategies for preparation of low-symmetry systems.

\section{Cross Condensation Between Two Different Dinitrile or 1,3-Diimino- isoindoline Components}

\subsection{Statistical condensation}

The statistical condensation method is the oldest synthetic method ${ }^{75,76}$ for the preparation of asymmetric phthalocyanines and is still the most popular for the preparation of the $3: 1\left(\mathrm{~A}_{3} \mathrm{~B}\right.$ type) compounds (Scheme 1). In general, statistical condensation method is non-selective and it could be expected that if the reactivity of the dinitrile A and dinitrile B are similar and these 
dinitriles are taken in equimolar quantities, all six possible products (Scheme 1) would be formed in statistical proportions (i.e. $\mathrm{A}_{4}(8.33 \%), \mathrm{A}_{3} \mathrm{~B}(25 \%), \mathrm{AABB}(25 \%), \mathrm{ABAB}(8.33 \%), \mathrm{AB}_{3}$ $(25 \%)$, and $\mathrm{B}_{4}(8.33 \%)$ ). Taking into consideration the well-known aggregation properties of phthalocyanines, preparative scale separation of such reaction mixtures by conventional chromatographic methods could be very challenging. As a result, the statistical condensation approach has never been used for targeting all six possible products. On the contrary, this method is predominantly used for preparation of the $\mathrm{A}_{3} \mathrm{~B}$ asymmetric phthalocyanine analogues and, in several cases, for the preparation of opposite $\mathrm{ABAB}$ and adjacent $\mathrm{AABB}$ compounds. Metal-free compounds could be prepared using direct cross condensation method, while the metal-ion template approach results in the formation of the corresponding phthalocyanine metal

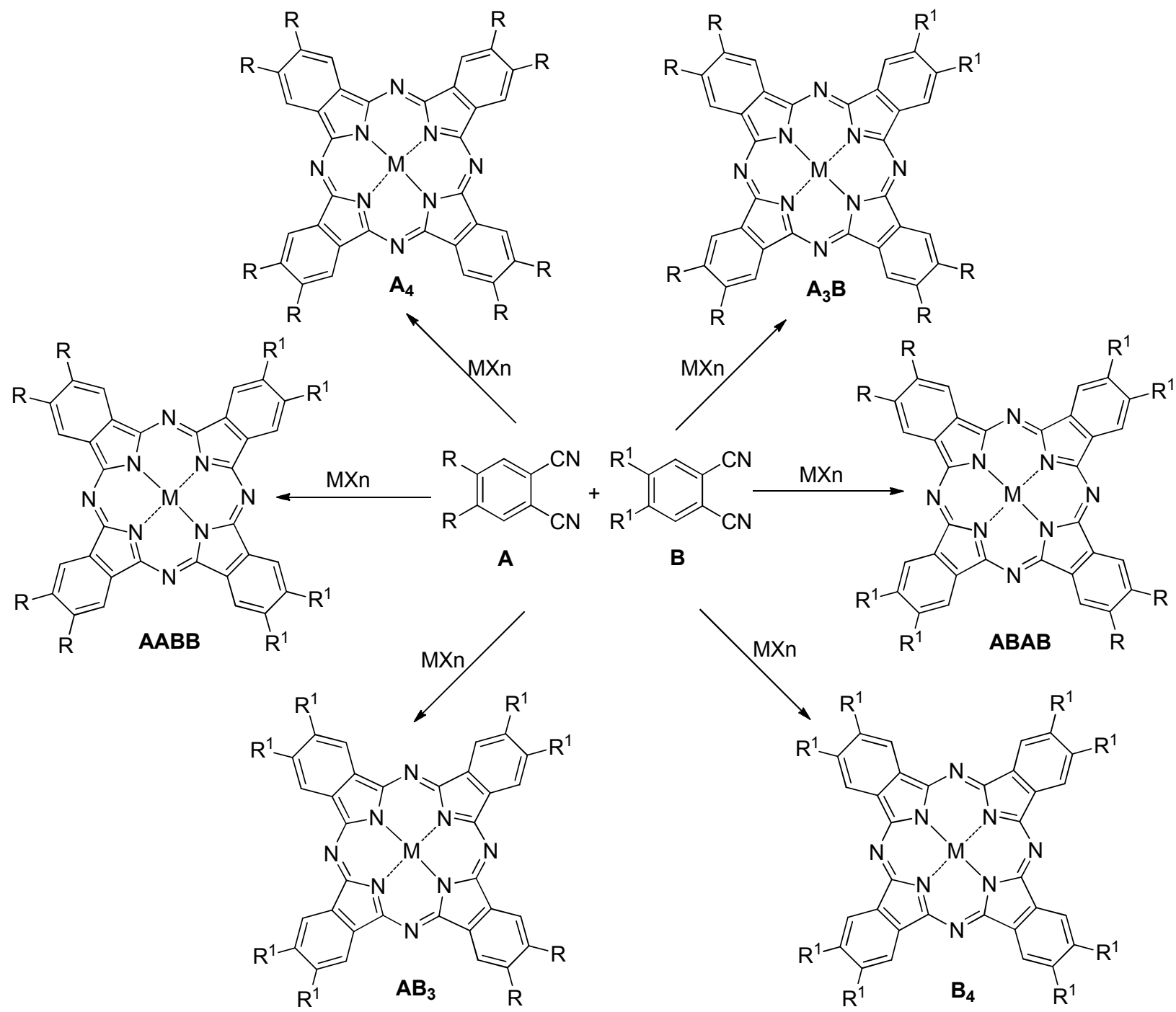

Scheme 1. General method for preparation of asymmetric phthalocyanines by the statistical condensation approach. 
complexes. The dinitrile component could be a substituted or unsubstituted phthalo-, 1,2naphthalo- or 2,3-naphthalo-nitrile, along with derivatives of fumaro- and maleo-nitriles. In some cases, substituted phthalonitriles could be part of another macrocycle and thus a crosscondensation reaction would result in the formation of di- or tri-macrocyclic systems such as, for example, phthalocyanine-triazolephthalocyanine hybrids $\mathbf{1}$ and $\mathbf{2}$ (Figure 2). ${ }^{108}$

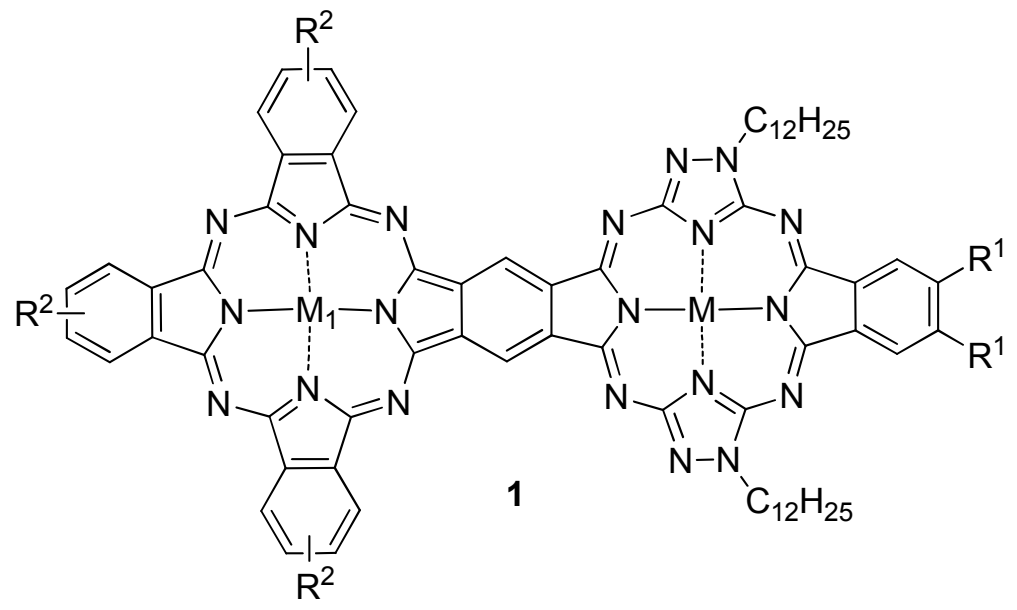

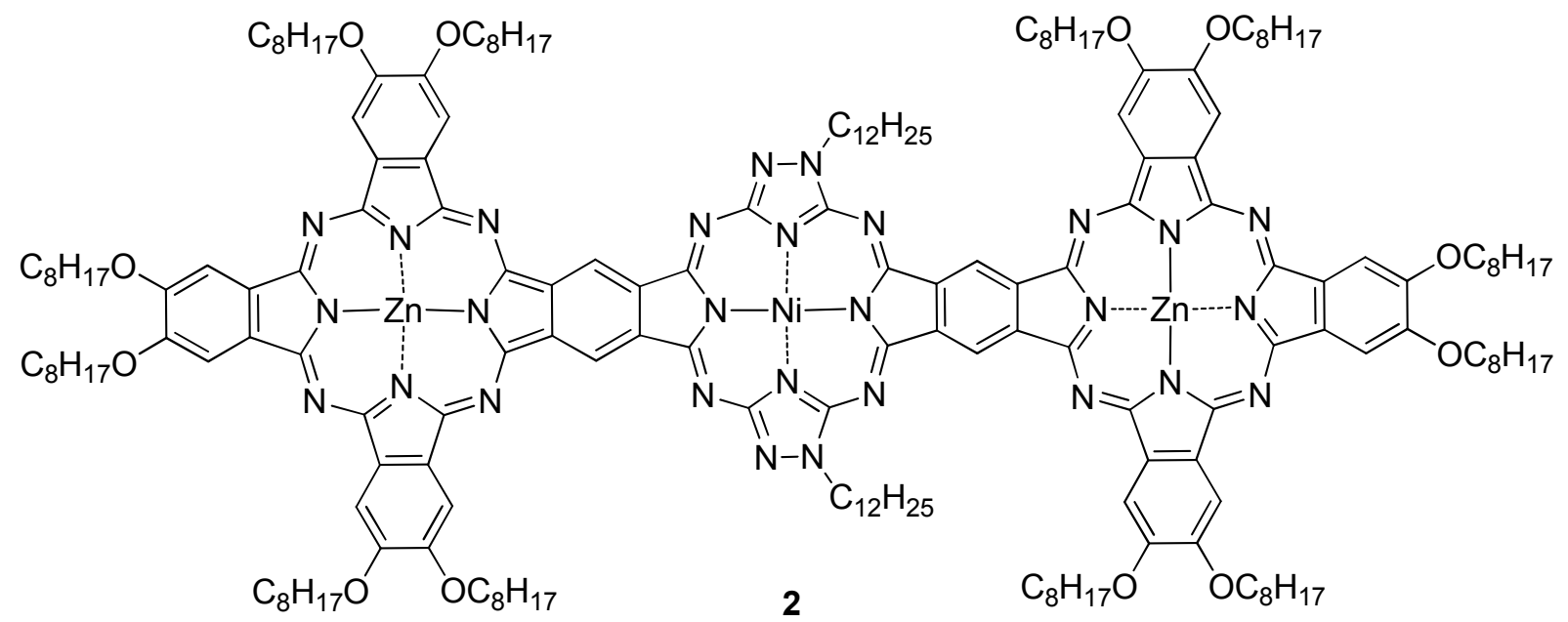

Figure 2. Examples of phthalocyanine-triazolephthalocyanine hybrids. ${ }^{108}$

When an $\mathrm{A}_{3} \mathrm{~B}$ asymmetric phthalocyanine is targeted, the stoichiometry and reactivity of the dinitriles or 1,3-diiminoisoindolines involved in the cross condensation are two key factors that need to be considered. If the reactivities of two dinitriles involved in the cross condensation are similar, then the simple 3:1 ratio of the nitrile $A$ and $B$ should lead to the formation of the symmetric $\mathrm{A}_{4}$ compound (33\%), the target asymmetric $\mathrm{A}_{3} \mathrm{~B}$ phthalocyanine as a major product (44\%), and the remaining $\mathrm{A}_{2} \mathrm{~B}_{2}, \mathrm{AB}_{3}$, and $\mathrm{B}_{4}$ compounds as minor products $(23 \%)$. Although 
experimental yields were found to be between 10 and $20 \%$ for the $A_{3} B$ phthalocyanine, the presence of all possible reaction products complicates the purification of the desired compound by conventional methods. In order to suppress formation of the unwanted $A_{2} B_{2}, A_{3}$, and $B_{4}$ compounds, a 9:1 (dinitrile $\mathrm{A}$ to $\mathrm{B}$ ) or higher ratio has been recommended and successfully used by several research groups. ${ }^{67-69,103,104}$ In this case, symmetric $\mathrm{A}_{4}$ phthalocyanine and asymmetric $\mathrm{A}_{3} \mathrm{~B}$ compound, essentially are the only reaction products, and thus separation of the reaction mixture is less complicated. Another useful tip for the preparation of asymmetric $A_{3} B$ systems was introduced by Cook and co-workers. ${ }^{89-92,109-111}$ This research group found that introduction of the substituents into the 3,- and 6-positions of the phthalonitrile facilitates separation of the symmetric $\mathrm{A}_{4}$ from the asymmetric $\mathrm{A}_{3} \mathrm{~B}$ system using conventional chromatography methods, apparently because of the lower aggregation ability of such phthalocyanines. Although the influence of electronic effects in the phthalonitrile on its reactivity is not clearly understood, it was suggested that a high A : B molar ratio should be used when the phthalonitrile B is more reactive than phthalonitrile $A$, while a close or even inverted $A$ : $B$ ratio should be used when the phthalonitrile $B$ is significantly less reactive than phthalonitrile A. ${ }^{67}$ This synthetic strategy is advantageously used to prepare functionalized phthalocyanines with moieties of biological relevance, such as carbohydrates ${ }^{113-116}$ or chalcones ${ }^{117}$ for medicinal applications.

An interesting variation of the cross-condensation method was recently developed by Luk'yanets and co-workers (Scheme 2). ${ }^{118-125}$ In this approach, one unsaturated or aromatic dinitrile was reacted with a simple tetramethylsuccinonitrile to target formation of the $A_{3} B$ tetraazachlorin-type macrocycles $\mathbf{3}$ and $\mathbf{4}$. In early attempts, metal-free compounds $\mathbf{3}$ were prepared using the lithium salt of $N, N$-dimethylaminoethanol, ${ }^{118-122}$ but it was shown very recently that yields of such $\mathrm{A}_{3} \mathrm{~B}$ tetraazachlorins $\mathbf{3}$ could be significantly improved when indium was used for template condensation followed by demetalation of the macrocycle with hydrochloric acid. ${ }^{124,125}$ The use of nickel ions as a template in this reaction results in the formation of the $\mathrm{A}_{3} \mathrm{~B}$ type nickel tetraazachlorins $\mathbf{4}$, $\mathrm{ABAB}$ type tetraazabacteriochlorins $\mathbf{5}$, and AABB type tetraazaisobacteriochlorins 6 (Scheme 2). ${ }^{118-123}$ A similar strategy was applied by Kobayashi and co-workers for the synthesis of a fullerene-containing tetraazachlorin derivative. $^{126-130}$

\subsection{Sterically driven cross condensation}

An interesting modification of the statistical cross condensation method was developed and implemented by several research groups between 1990 and $2000 .^{80,82,83,85-87,131}$ In this approach, one of the dinitriles or 1,3-diiminoisoindolines (say reactant B) should have bulky rigid groups at 3,6-positions. In this case, because of the steric hindrance between the bulky groups in close vicinity, formation of the sterically strained adjacent $\mathrm{AABB}$, as well as $\mathrm{AB}_{3}$, and $\mathrm{B}_{4}$ compounds is significantly suppressed, while the formation of the less sterically crowded $A_{4}, A_{3} B$, and 


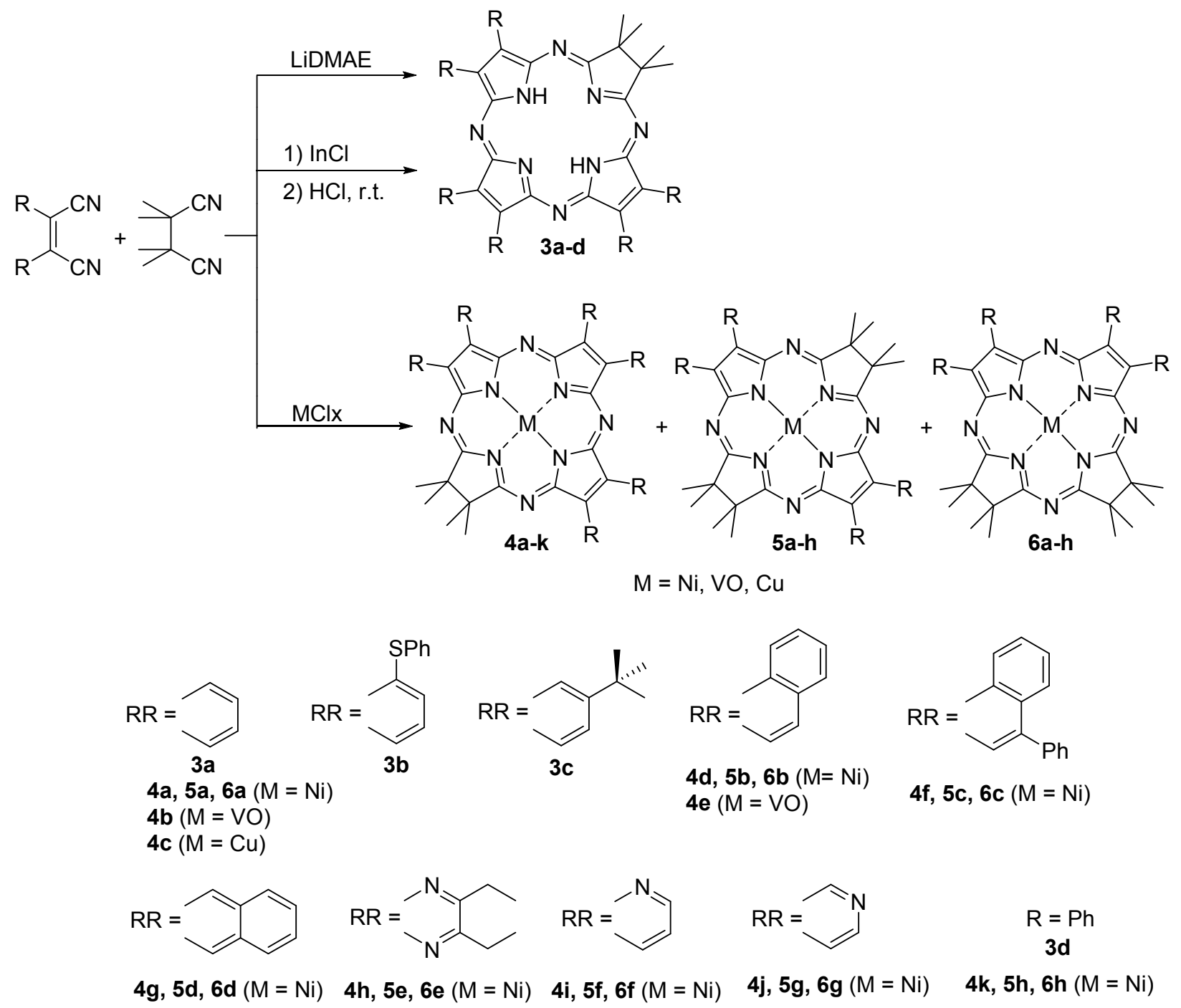

Scheme 2. General synthetic strategies for preparation of tetraazachlorins, tetraazabacteriochlorins, and tetraazaisobacteriochlorins.

opposite $\mathrm{ABAB}$ compounds is favored even at a 1:1 ratio of the reactants $\mathrm{A}$ and $\mathrm{B}$ (Scheme 3). So far, phenyl and tert-butyl groups have been proposed as the rigid substituents in this approach, and such phthalonitriles are relatively easy to prepare. For instance, 3,4,5,6-tetraphenylphthalonitrile can be prepared from the commercially available 2,3,4,5-tetraphenylcyclopentadienone and chlorofumaronitrile. ${ }^{132}$ Another significant advantage of this method is that bulky rigid substituents at the 3 and 6-positions simplify the chromatographic separation of the target compounds. With more conformationally flexible substituents such as $n$-alkyl groups at the 3,6-positions, the corresponding phthalonitriles are not sterically crowded enough to prevent the formation of adjacent $\mathrm{AABB}, \mathrm{AB}_{3}$, and $\mathrm{B}_{4}$ products. 


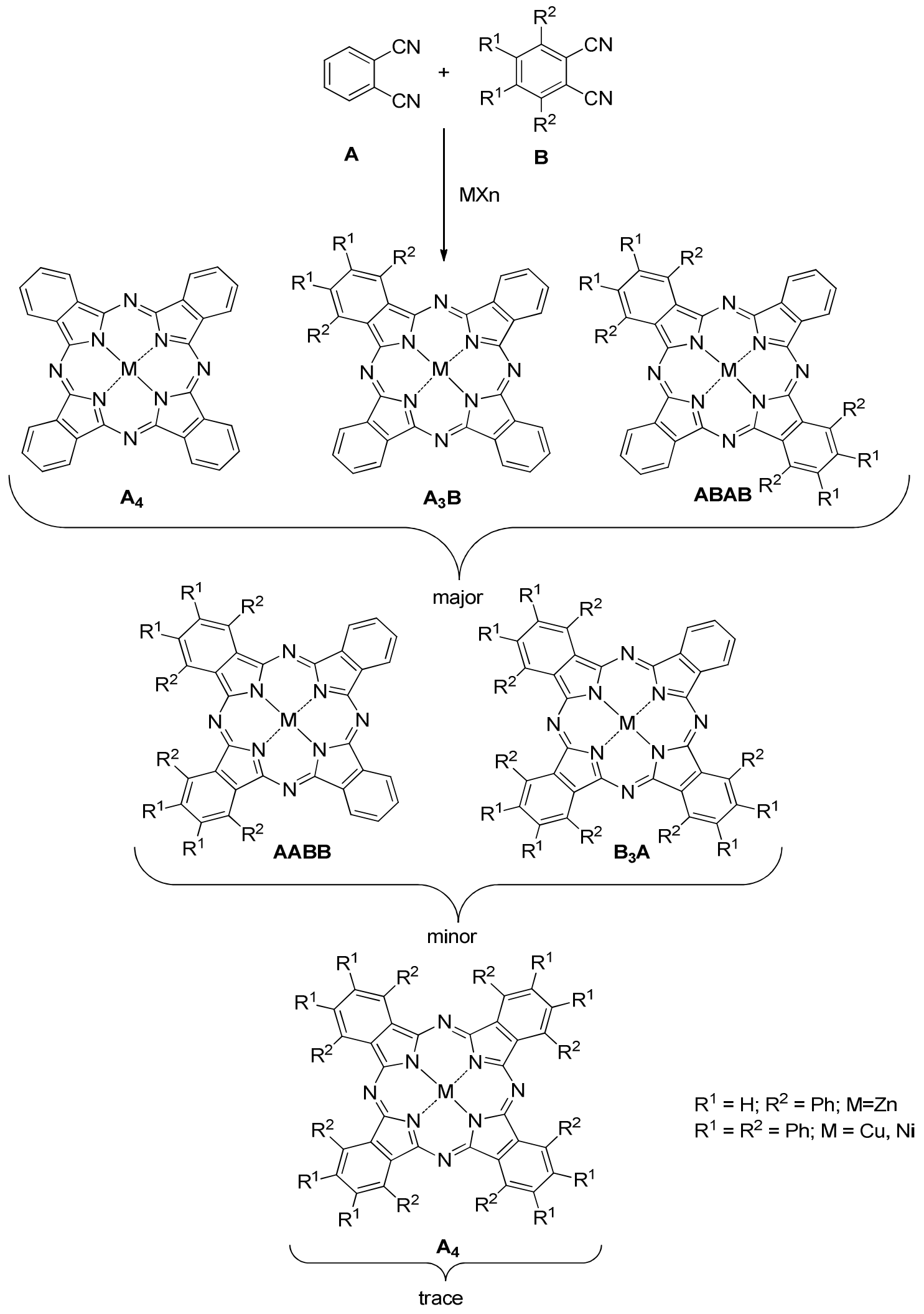

Scheme 3. Sterically driven cross-condensation reaction approach for preparation of asymmetric phthalocyanines. 


\subsection{Polymer support-based approach}

A polymer support-based approach for preparation of asymmetric phthalocyanines was pioneered by Leznoff and co-workers in 1982..$^{93,94}$ Because of the nature of this synthetic strategy, it used exclusively for preparation of the $A_{3} B$ type of phthalocyanines (Scheme $4 A$ ). In this approach, a 4-substituted phthalonitrile or 1,3-diiminoisoindoline (B) is first coupled, usually using ether bond formation, to an appropriately functionalized polymer. Such phthalonitrile or 1,3-diiminoisoindoline containing polymer then reacted with a large excess of second phthalonitrile or 1,3-diiminoisoindoline (A) in appropriate solvent, which solubilize A but not

polymer-supported B. ${ }^{93-95}$ Symmetric phthalocyanine $\mathrm{A}_{4}$, which is the major reaction product could be removed by simple washing of the reaction mixture with organic solvent, while polymer-bound asymmetric $\mathrm{A}_{3} \mathrm{~B}$ compound 7 remains insoluble. Further treatment of the polymer-bound asymmetric $\mathrm{A}_{3} \mathrm{~B}$ phthalocyanine with an acid cleaves polymer backbone and liberates the target $A_{3} B$ compound $\mathbf{8}$ into solution, which can be filtered from the remaining insoluble polymeric support. The typical yields of the asymmetric $A_{3} B$ phthalocyanines in this method were observed around $20 \%$.

In a different variation of this synthetic strategy, Wöhrle and co-workers used functionalized silica gel supports to couple substituted phthalonitrile (B) to the surface. ${ }^{133}$ In this case, the silica gel carriers were modified with the terminal primary organic amines prior their coupling with 4(3,4-dicyanophenoxy)benzoic acid chloride (Scheme 4B). Asymmetric $\mathrm{A}_{3} \mathrm{~B}$ phthalocyanine 10 was cleaved from the surface by the alkaline hydrolysis of the amide bond in phthalocyanine 9 in $\mathrm{TFH} /$ water mixture.

The key advantage of the polymer support-based method is elimination of the necessity of tedious chromatographic steps for the product purification. There are two major current drawbacks for such synthetic strategy, however, which should be overcome for the large-scale preparation of $\mathrm{A}_{3} \mathrm{~B}$ systems. First, despite the variety of commercially available polymeric supports and silica gels, choice of immobilized dinitriles or 1,3-diiminoisoindolines (B) is currently limited to those which can form either ether or amide bond with the support surface and later be easily cleaved by the acidic or alkaline hydrolysis. Such hydrolysis requires that the substituents (if present) in the second dinitrile or 1,3-diiminoisoindoline (A) should be stable for hydrolysis conditions. Second, an achievable target $\mathrm{A}_{3} \mathrm{~B}$ phthalocyanine load on polymer or silica gel surfaces is quite limited by the porosity, functionalization site availability, and topology of the carrier. For instance, only $0.6-6 \mathrm{mg}\left(7.7 \times 10^{-7}-7.4 \times 10^{-6} \mathrm{~mol}\right)$ of the $\mathrm{A}_{3} \mathrm{~B}$ phthalocyanine were obtained from $1 \mathrm{~g}$ of modified silica gel with covalently bound phthalocyanine by Wöhrle and co-workers. ${ }^{133}$

\subsection{Self and cross-condensation strategy involving bis(phthalonitriles)}

In the simplest variation of this synthetic strategy, bridged 3,3'- or 4,4'-bis(phthalonitriles) or the corresponding bis(1,3-diiminoisoindolines) (B-B) used in the cross-condensation reaction with an excess of the second substituted or unsubstituted phthalonitrile or 1,3-diiminoisoindoline 
A)<smiles>N=C1NC(=N)c2cc(OCCOc3ccc4c(c3)C(=N)NC4=[PH+])ccc21</smiles>

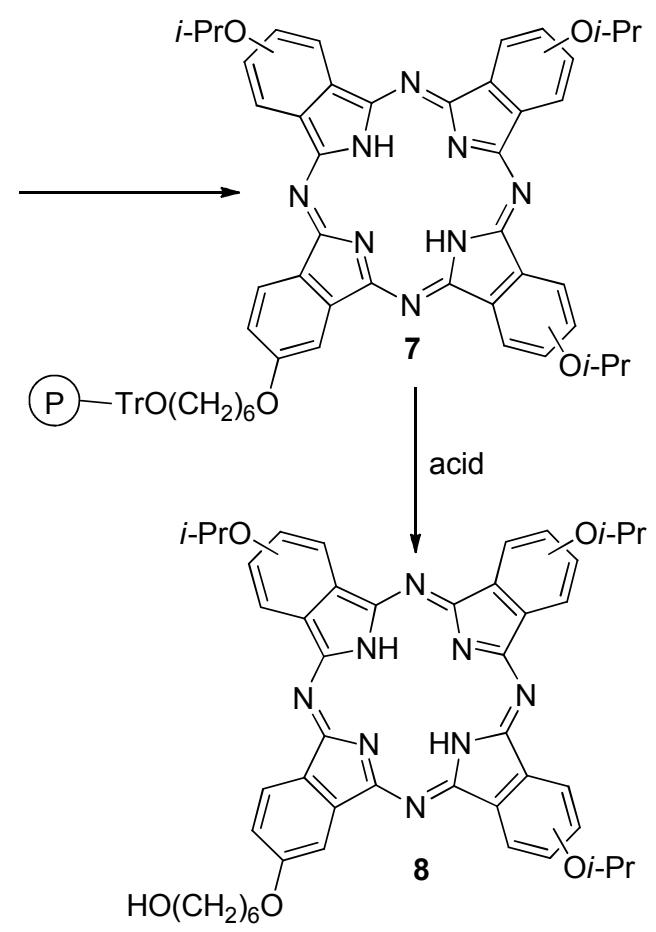

B)<smiles>CC[Si](OC)(Oc1ccccc1)Oc1ccccc1</smiles><smiles>CC(C)(C)c1ccc(Oc2ccc(C#N)c(C#N)c2)cc1</smiles><smiles>[R]Oc1ccc(C(C)(C)C)cc1</smiles>

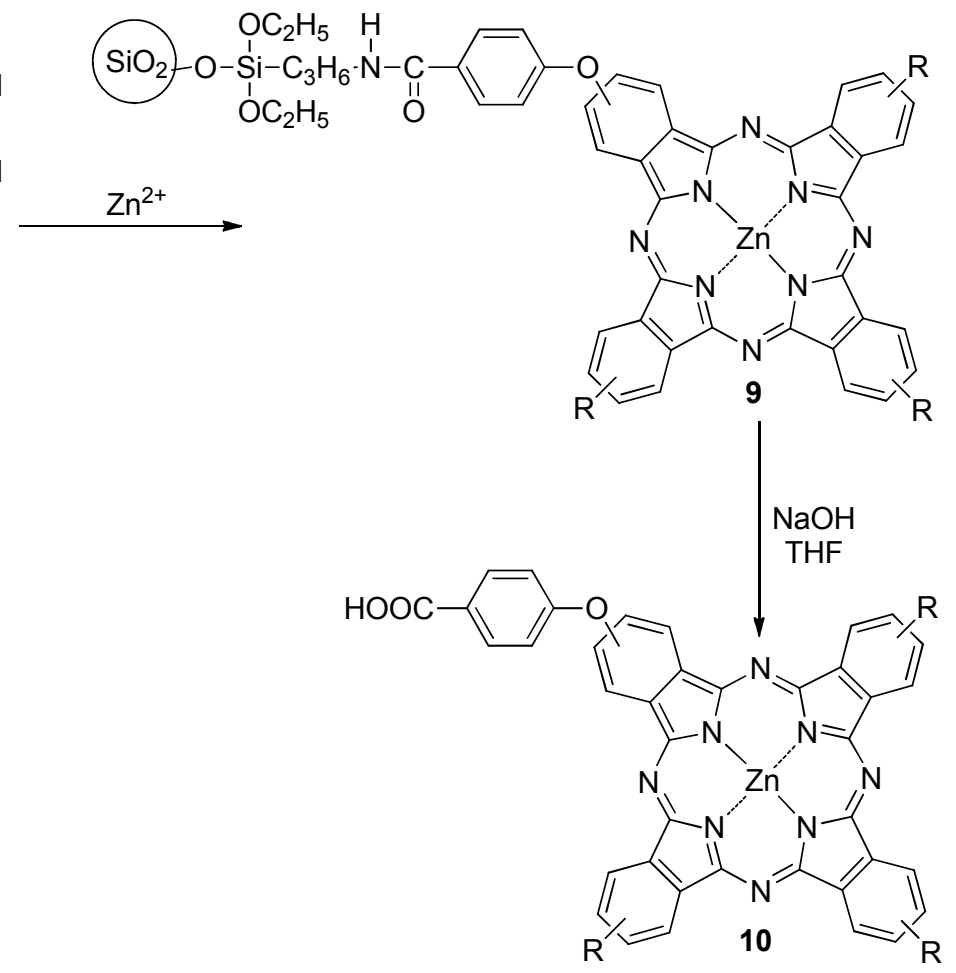

Scheme 4. General strategy for preparation of $\mathrm{A}_{3} \mathrm{~B}$-type asymmetric phthalocyanines using polymer support-based approach. 


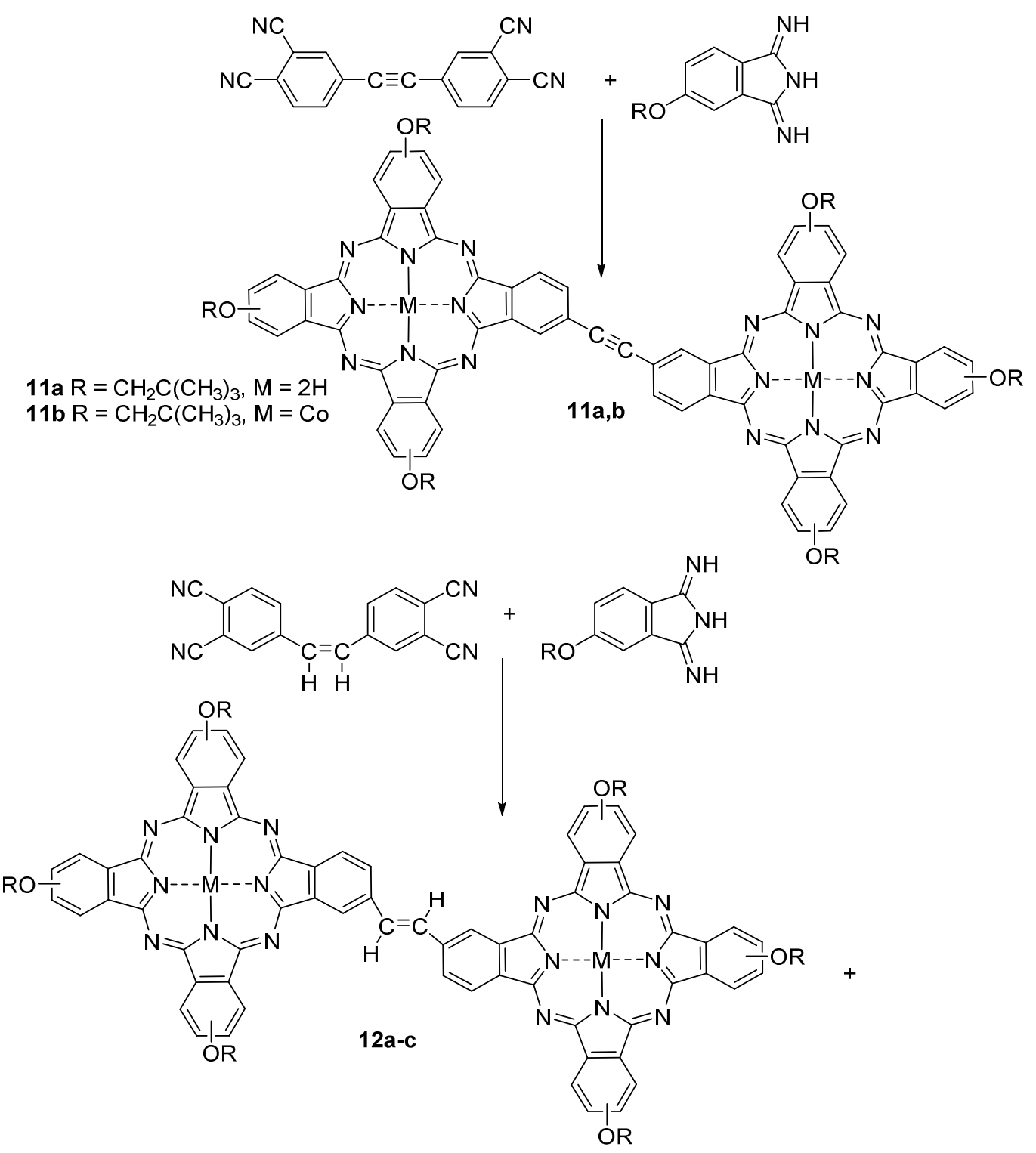

12a, $13 \mathrm{R}=\mathrm{CH}_{2} \mathrm{C}\left(\mathrm{CH}_{3}\right)_{3}, \mathrm{M}=2 \mathrm{H}$

12b R $=\mathrm{CH}_{2} \mathrm{C}\left(\mathrm{CH}_{3}\right)_{3}, \mathrm{M}=\mathrm{Co}$

12c $\mathrm{R}=\mathrm{CH}_{2} \mathrm{C}\left(\mathrm{CH}_{3}\right)_{3}, \mathrm{M}=\mathrm{Zn}$

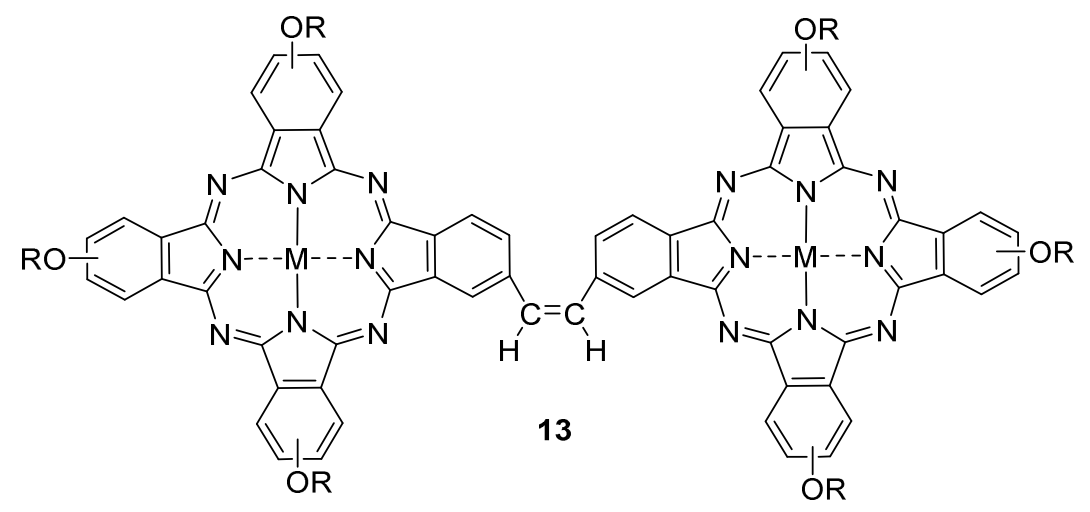

Scheme 5. Synthetic pathways for the preparation of co-planar asymmetric $\mathrm{A}_{3} \mathrm{~B}-\mathrm{BA} \mathrm{A}_{3}$ type phthalocyanines. 
precursor $\mathrm{A}$ to form, for instance, the asymmetric $\mathrm{A}_{3} \mathrm{~B}-\mathrm{BA}_{3}$ dimeric phthalocyanine products $\mathbf{1 1}$ - 13 (Scheme 5). Similar to the standard synthesis of asymmetric $A_{3} B$ compounds described earlier, the main by-product in such synthesis is symmetric $\mathrm{A}_{4}$ phthalocyanine, which could be eliminated by the conventional chromatographic methods. Depending on rigidity of the linking group in starting B-B phthalonitrile, planar or co-facial dimeric phthalocyanines could be prepared in extreme cases (Scheme 5). ${ }^{96}$ For instance, Lever, Leznoff and co-workers reported variety of $\mathrm{A}_{3} \mathrm{~B}-\mathrm{BA}_{3}$ type asymmetric dimeric phthalocyanines connected via alkynyl-, alkenyl-, and saturated hydrocarbon bridges. ${ }^{96}$ Unsaturated bridging groups in these compounds force coplanar geometry of phthalocyanines and though to facilitate electronic coupling between two macrocycles although no strong coupling was observed in alkynyl- and alkenyl-derivatives of dimeric phthalocyanines 12 and $\mathbf{1 3}$ (Scheme 5). ${ }^{96}$

A)
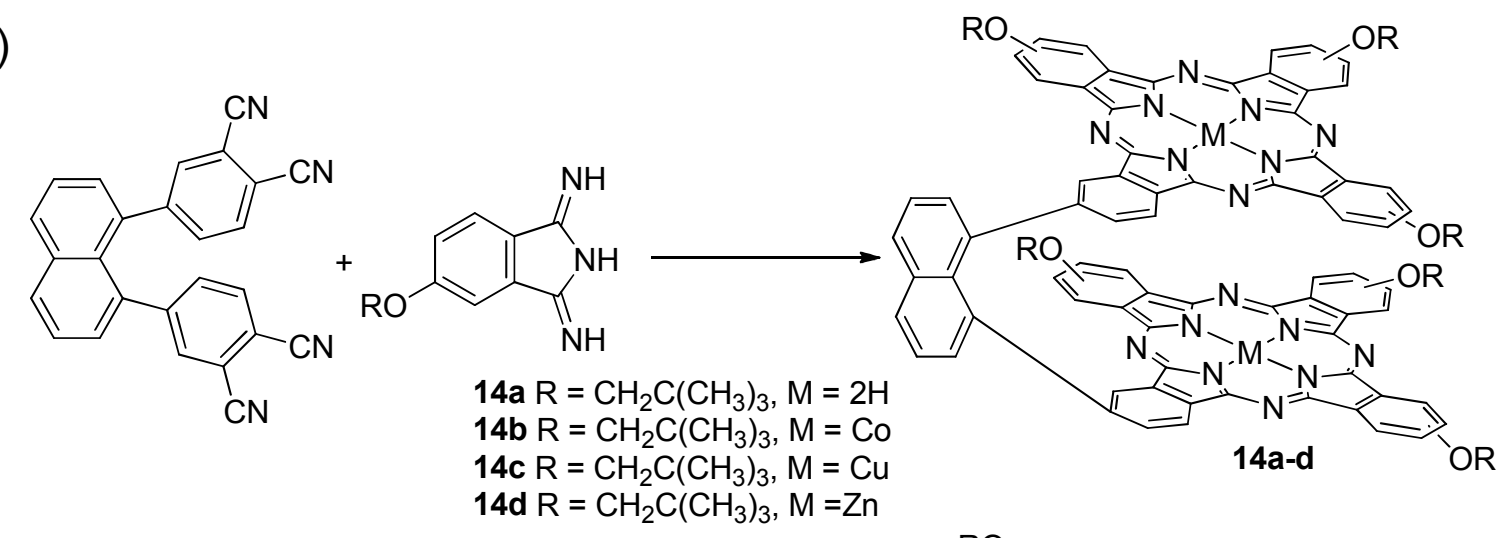

B)
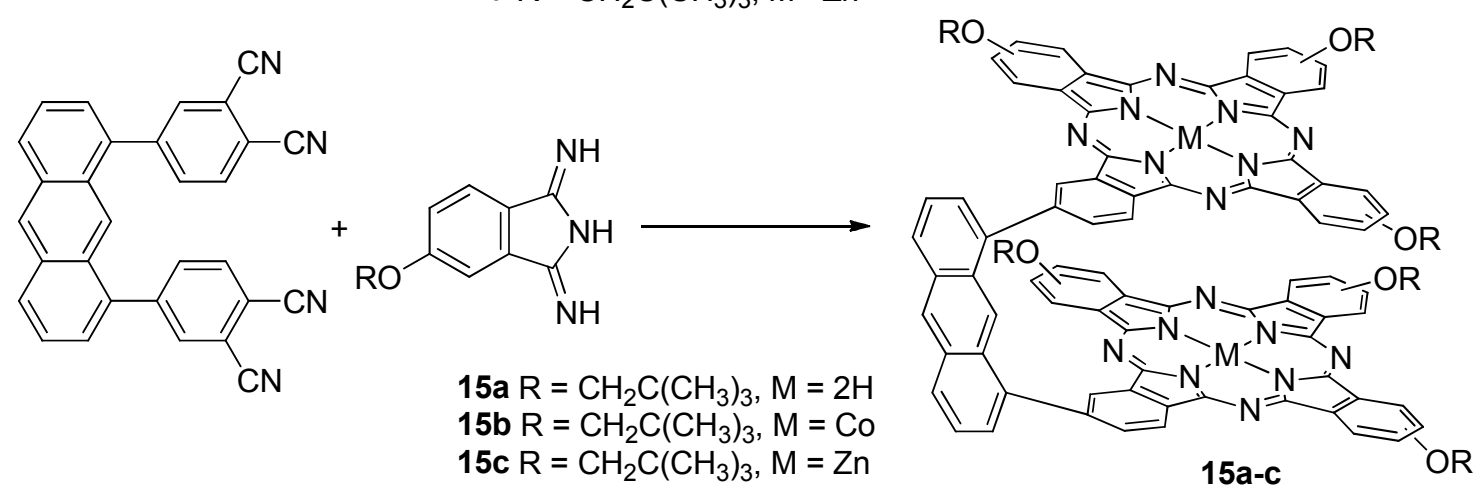

C)

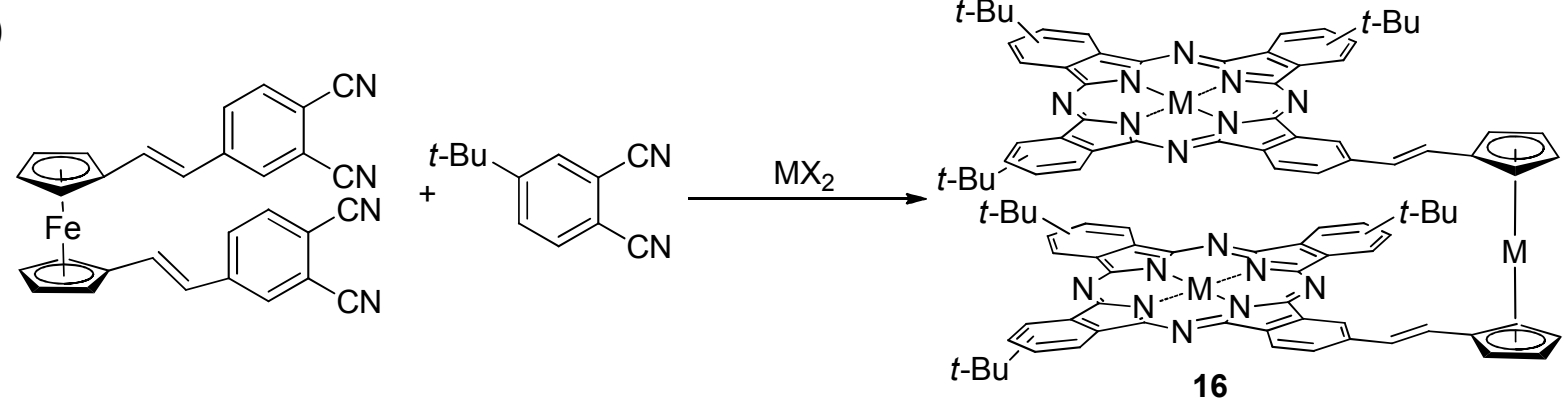

Scheme 6. Synthetic strategies for the preparation of cofacial $\mathrm{A}_{3} \mathrm{~B}-\mathrm{BA}_{3}$ type asymmetric phthalocyanines. 
The other extreme of this strategy is the formation of a co-facial dimeric phthalocyanine compound as reported, for instance, by Leznoff, Lever and co-workers ${ }^{134}$ as well as by Torres and co-workers ${ }^{135}$ (Scheme 6). In the first example, naphthalene or anthracene-containing bis(phthalonitriles) were statistically condensed with the substituted phthalonitrile to form cofacial naphthalene or anthracene-bridged $\mathrm{A}_{3} \mathrm{~B}-\mathrm{BA}_{3}$ systems 14, 15 (Scheme 6A,B). ${ }^{134}$ In the second, a ferrocene-containing bis(phthalonitrile) was used as starting material for a cross condensation reaction with 4-tert-butylphthalonitrile (Scheme 6C). ${ }^{135}$ In all cases, UV-vis spectroscopy of the final asymmetric $\mathrm{A}_{3} \mathrm{~B}-\mathrm{BA}_{3}$ compounds 14-16 were suggestive of a co-facial arrangement of two phthalocyanine macrocycles, which varied depending on the type of linking group and which facilitates potential electronic coupling in these systems. A similar co-facial orientation in asymmetric $\mathrm{A}_{3} \mathrm{~B}-\mathrm{BA}_{3}$ phthalocyanines 17 and 18 could be achieved using $o$ xylylene or BINOL-based bis(phthalonitriles), which provide the desired conformational rigidity (Figure 3). ${ }^{136,137}$
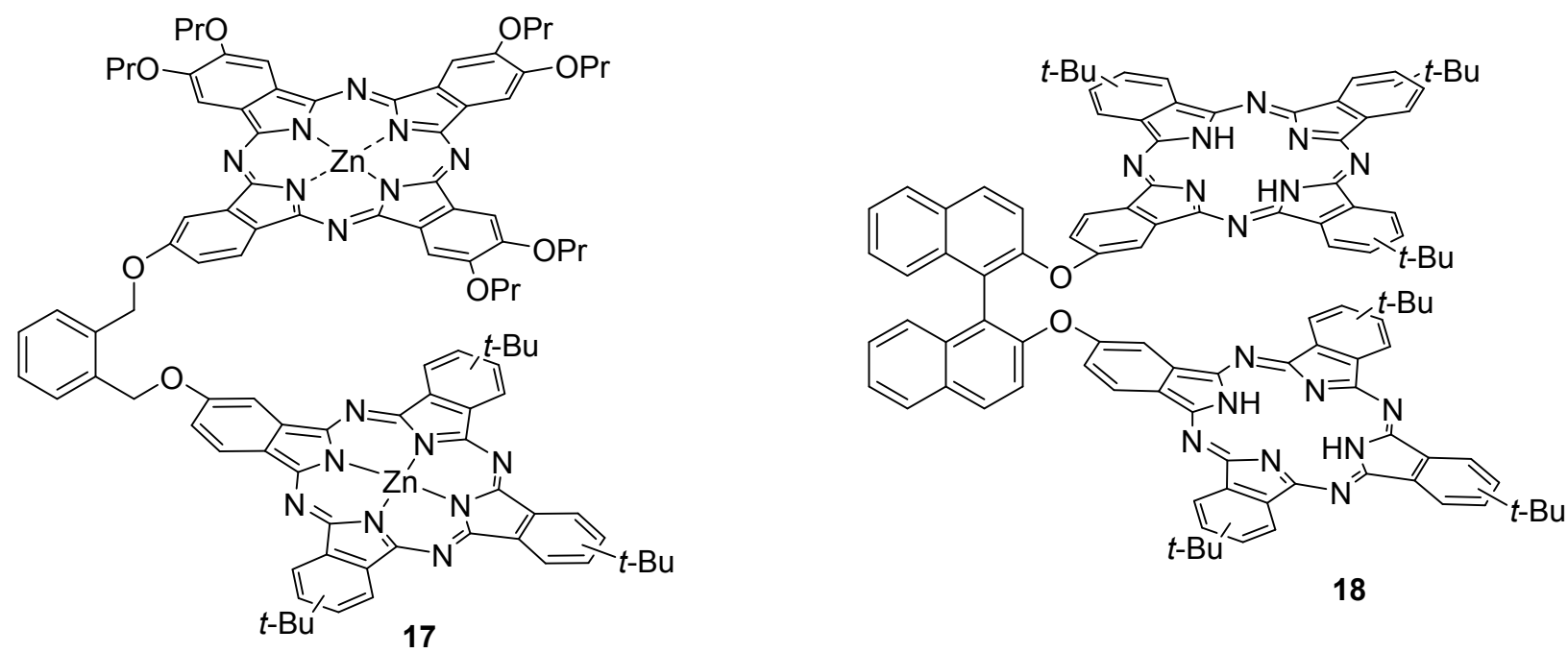

Figure 3. Representative examples of cofacial asymmetric $\mathrm{A}_{3} \mathrm{~B}-\mathrm{BA}_{3}$ type phthalocyanines

Finally, when saturated conformationally flexible linking groups used for the preparation of $\mathrm{A}_{3} \mathrm{~B}-\mathrm{BA}_{3}$ systems, the conformation of the resulting dimeric phthalocyanine compounds could easily adopt any configuration between co-planar and co-facial. ${ }^{96}$ An interesting case of an $\mathrm{A}_{3} \mathrm{~B}-\mathrm{BA}_{3}$ system was reported by Kobayashi and co-workers (Scheme 7). ${ }^{138}$ Prepared by crosscondensation between tetracyanoparacyclophane and a substituted phthalonitrile, the dimeric phthalocyanines 19a,b have two co-planar phthalocyanine macrocycles connected through a paracyclophane fragment, which provides $\pi-\pi$ conjugation for the system and shifts the Q-band into the near IR region. 


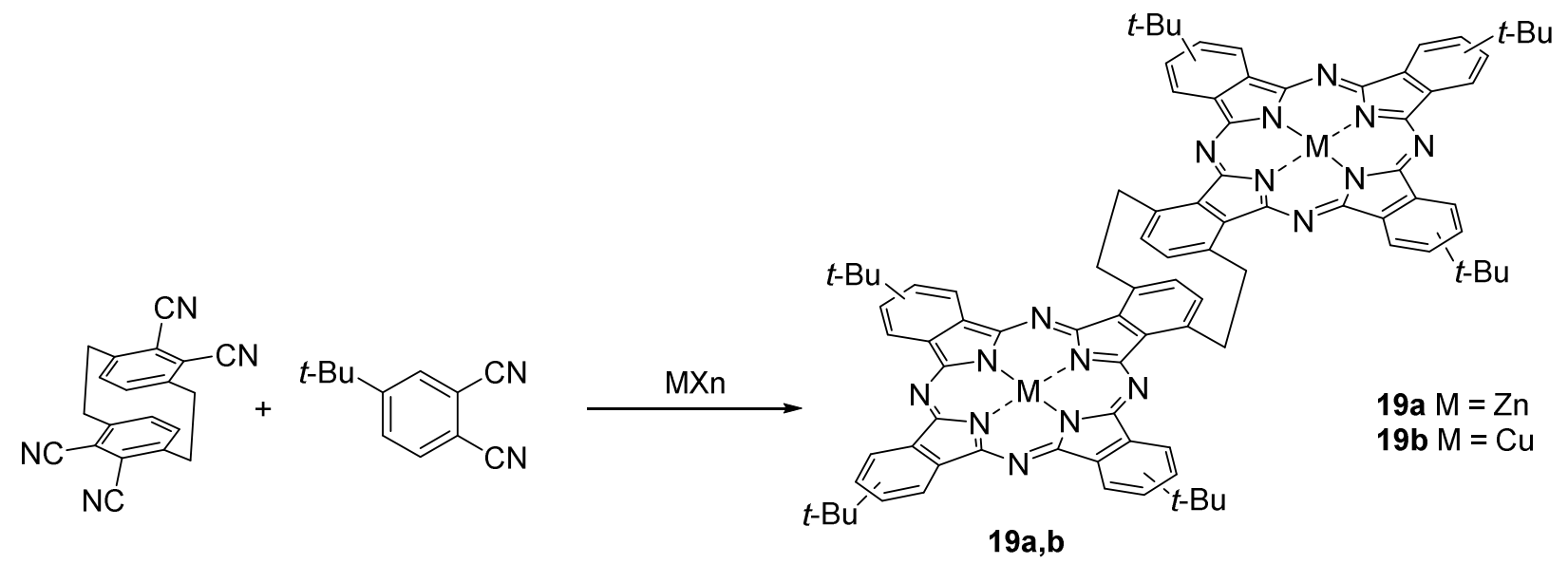

Scheme 7. Synthesis of paracyclophane-conjugated $\mathrm{A}_{3} \mathrm{~B}-\mathrm{BA}_{3}$ phthalocyanines.

Other interesting asymmetric systems which rely on the bis(phthalonitrile) cross condensation approach are the fully conjugated planar extended phthalocyanine analogues of Scheme 8. ${ }^{139}$ In these cases, tetracyano-benzene, -naphthalene or -anthracene precursors undergo crosscondensation with substituted phthalonitriles to form fused bis-, tris-, and higher rank asymmetric phthalocyanine derivatives. Simon, ${ }^{140-142}$ Kobayashi, ${ }^{142-146}$ Tomilova, ${ }^{147-154}$ and their respective co-workers reported several such systems, while Wöhrle and co-workers prepared an interesting set of linear dimer $\mathbf{2 0}$ and linear and angular fully conjugated phthalocyanine trimers 21 and $22 .{ }^{139}$

The synthetic strategy for the synthesis of monophthalocyanines using bis(phthalonitrile) precursors was first developed by Leznoff and co-workers for a single-isomer preparation of a tetrasubstituted symmetric phthalocyanine (Scheme 9A). ${ }^{155}$ Self-condensation of the 3,3'bisphthalonitrile leads to the formation of pure 1,11,15,25-tetrasubstituted phthalocyanines 23a-d in $7-21 \%$ yields along with polymeric and oligomeric by-products.

Kobayashi and co-workers have extended this synthetic strategy to the preparation of asymmetric adjacent AABB phthalocyanines. ${ }^{156}$ In their modification, a chiral or non-chiral 3,3'bis(phthalonitrile) undergoes cross-condensation with an appropriate phthalo- or naphthalonitrile to form symmetric $\mathrm{A}_{4}$ and asymmetric adjacent $\mathrm{AABB}$ phthalocyanines 24a-f in 1.5-3.3\% yields (Scheme 9B). Although formation of the other asymmetric and symmetric by-products in this reaction is unavoidable and thus purification of the target adjacent AABB phthalocyanines requires extensive chromatography steps, this method allows formation of rare AABB type compounds in a reasonably selective way. ${ }^{156-161}$ Moreover, the key advantage of the use of the bis(phthalonitriles) with short rigid bridging groups similar to, for instance, 2,2'-dihydroxy-1.1'binaphthyl, is suppressed formation of oligomeric phthalocyanines by the self-condensation reaction of such building blocks. 

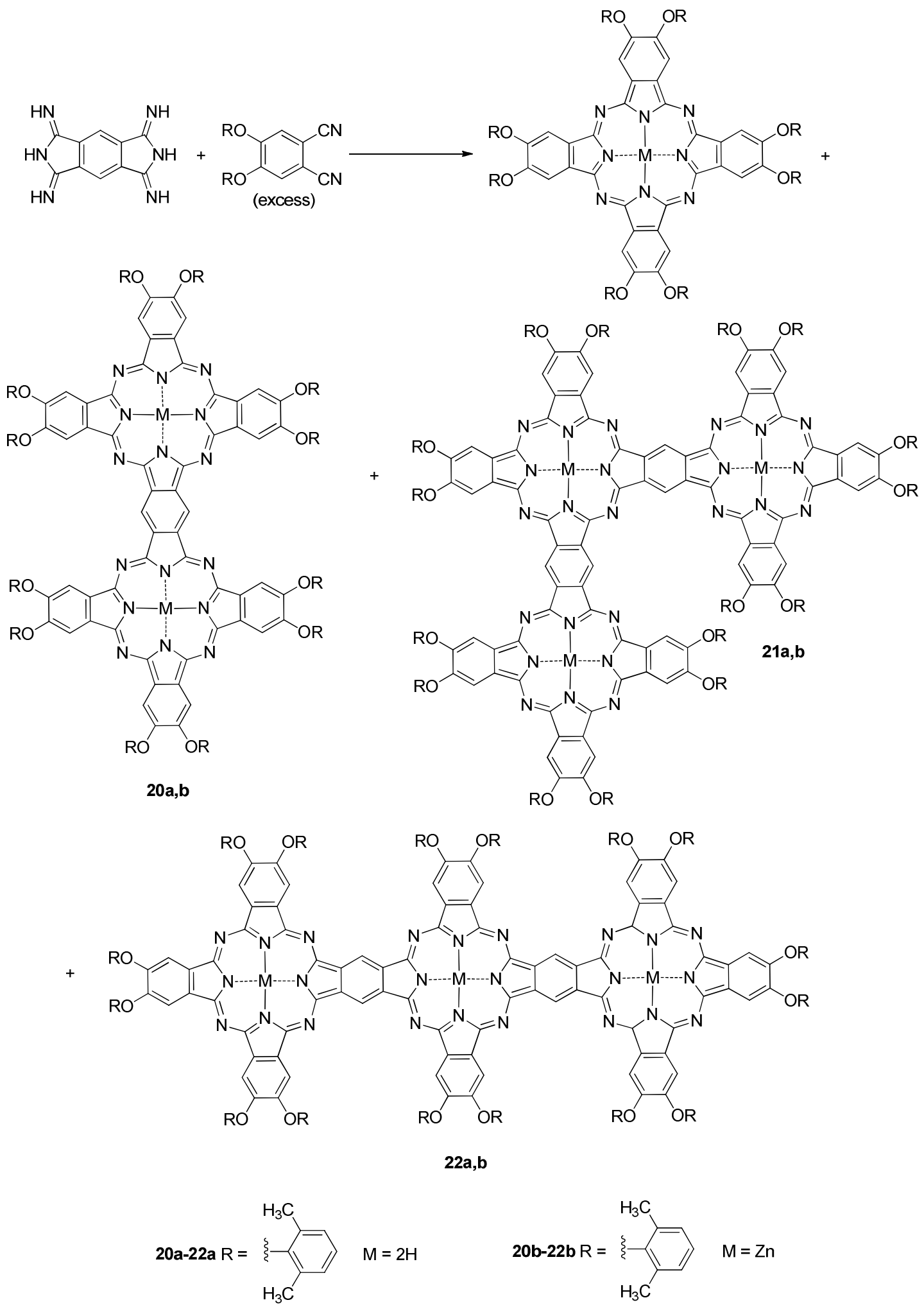

Scheme 8. Synthetic approach to the preparation of fully conjugated asymmetric phthalocyanines. 
A)

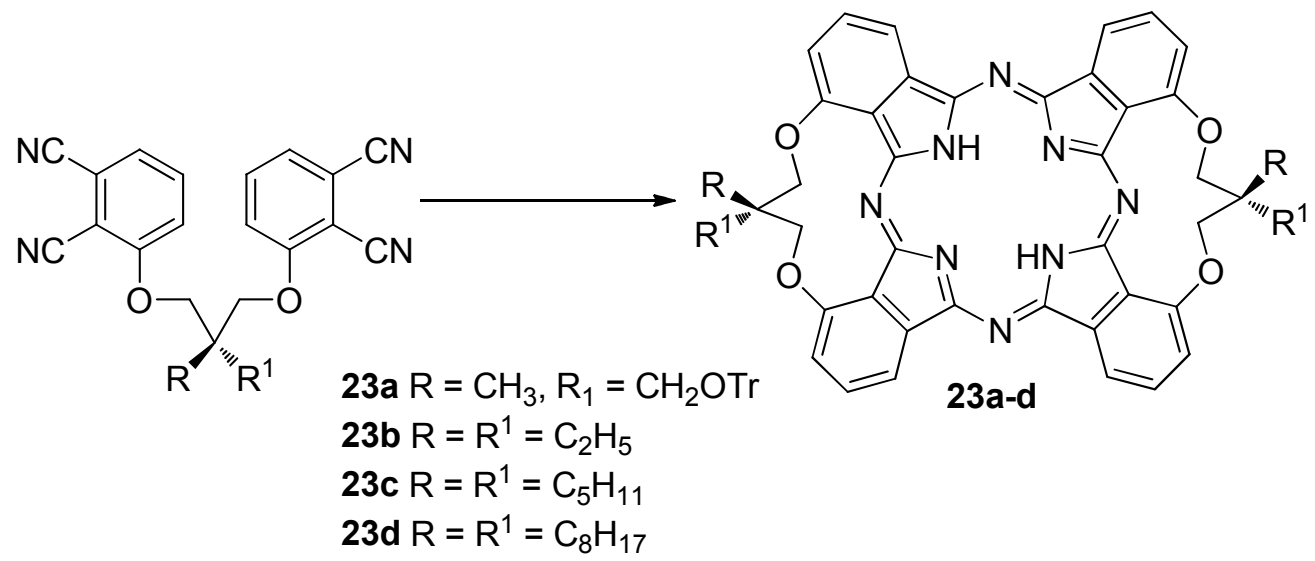

B)<smiles>[R]c1cc(Oc2cccc(C#N)c2C#N)c(-c2cc([R])c([R])cc2Oc2cccc(C#N)c2C#N)cc1[R]</smiles>

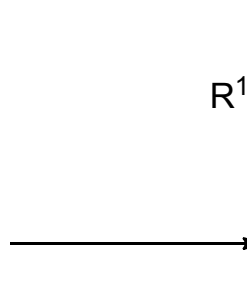<smiles>[R]c1cc([R])c(C#N)cc1[R]</smiles>

24a $\mathrm{R}^{1}=t-\mathrm{Bu}, \mathrm{R}^{2}=\mathrm{H}, \mathrm{M}=\mathrm{Co}$

24b $\mathrm{R}^{1}=\mathrm{OC}_{6} \mathrm{H}_{5}, \mathrm{R}^{2}=\mathrm{H}, \mathrm{M}=2 \mathrm{H}$

24c $\mathrm{R}^{1}=\mathrm{O}\left(\mathrm{CH}_{3}\right)_{3} \mathrm{CC}_{6} \mathrm{H}_{5}, \mathrm{R}^{2}=\mathrm{H}, \mathrm{M}=2 \mathrm{H}$

24d $\mathrm{R}^{1}=\mathrm{OC}_{6} \mathrm{H}_{5} \mathrm{SO}_{3} \mathrm{Na}, \mathrm{R}^{2}=\mathrm{H}, \mathrm{M}=2 \mathrm{H}$

24e RR =<smiles>C1=CCC=CC1</smiles><smiles></smiles>

24f $R R=$

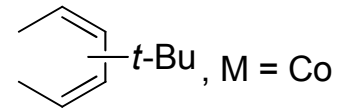

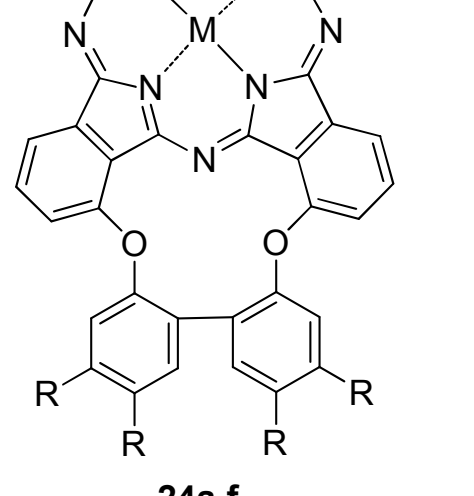

Scheme 9. Directed synthesis of AABB-type asymmetric phthalocyanines.

\section{Cross Condensation Between Phthalonitrile or 1,3-Diiminoisoindoline and Non-nitrile Components}

\subsection{Cross condensation between phthalonitrile and anhydride/imide components}

Because of the large difference in reactivity between the phthalonitrile or 1,3-diiminoisoindoline component (A) and anhydride or amide component (B), cross-condensation using such reactants is rarely used in the preparation of asymmetric phthalocyanines and their analogues. One example which uses this strategy is the cross-condensation between phthalo- or 1,2-naphthalonitrile as $\mathrm{A}$ and 5,5-dimethyl-1,3-oxazolidine-2,4-dione as B, using a nickel template. In this 
case, symmetric $A_{4}$ phthalocyanine and asymmetric $A_{3} B \quad \beta$-oxatetraazachlorins 25a-c $(4-8 \%$ yield) were formed (Scheme 10). ${ }^{162}$ Another example of such an approach is the cross condensation between 4-nitrophthalimide and 3,6-dialkoxyphthalonitrile in the presence of copper acetate, urea, and ammonium molybdate, to form mono-nitro- $\mathrm{A}_{3} \mathrm{~B}$ type copper phthalocyanine. ${ }^{163}$

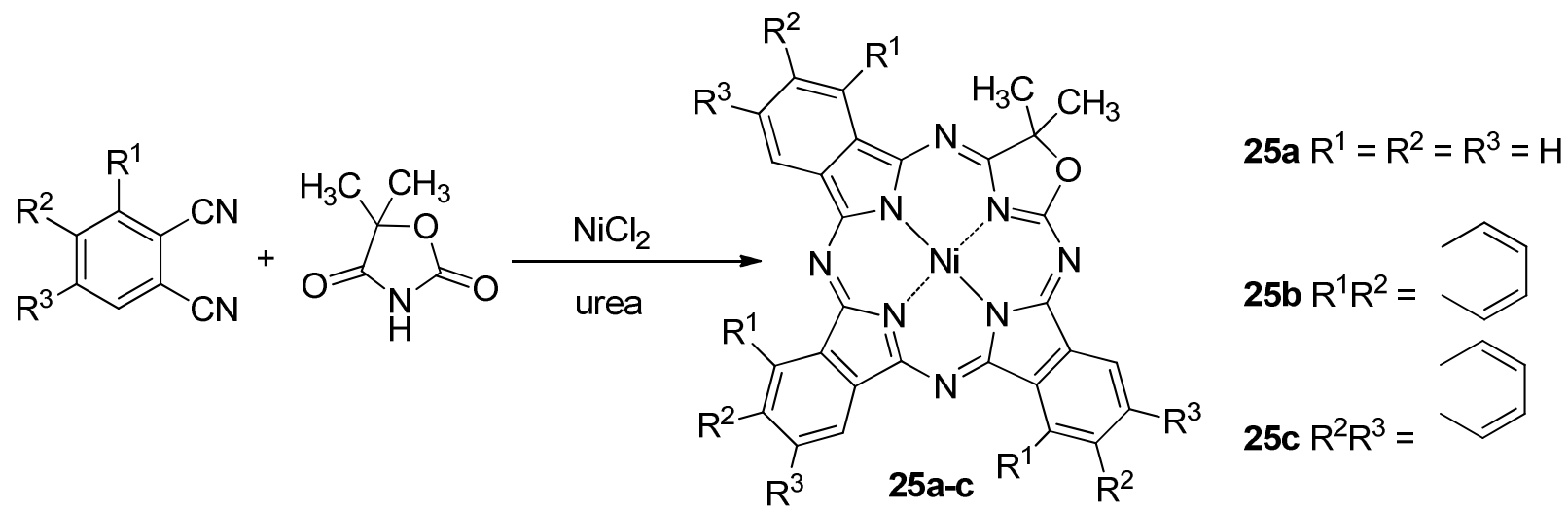

Scheme 10. General strategy for the preparation of tribenzotetraazachlorins using dinitrile and imide components.

\subsection{Cross condensation between nitrile and 1,1,3-trichloro- $1 H$-isoindole or isoindoline-1,3- dithione components}

In theory, the $1: 1$ cross condensation reaction between 1,3-diiminoisoindoline (A) derivatives and 1,1,3-trichloro- $1 \mathrm{H}$-isoindole (B) derivatives should result in selective formation of the opposite type $\mathrm{ABAB}$ asymmetric phthalocyanines. Indeed, in the first two reports on this reaction, dating back to $1977^{164}$ and $1990,{ }^{97}$ the authors claimed that the effective $D_{2 \mathrm{~h}}$ symmetry $\mathrm{ABAB}$ phthalocyanine forms exclusively in up to $50 \%$ yield when a $1: 1$ ratio of $\mathrm{A}$ and $\mathrm{B}$ were used in the presence of organic base and a reducing agent. Later, however, other research groups which applied this method for the selective preparation of $\mathrm{ABAB}$ systems reported significant contamination of the product mixture by the $\mathrm{A}_{3} \mathrm{~B}$ asymmetric phthalocyanine derivative. As a result, observed yields of $A B A B$ products 26a-c were significantly lower $(15-25 \%)$, and conventional purification methods should be used to obtain a target $\mathrm{ABAB}$ compound in pure form. ${ }^{165-174}$ It seems that this synthetic approach has low sensitivity to the substituents present in the 1,1,3- trichloro- $1 \mathrm{H}$-isoindole as well as the 1,3-diiminoisoindoline derivative (Scheme 11A).

In a recent report, 1,1,3-trichloro- $1 H$-isoindole (A) was used for cross condensation with two different 4,5- (B) and 4-substituted (C) 1,3-diiminoisoindolines. The authors reported that formation of the first ever $\mathrm{ABAC}$ asymmetric phthalocyanine $\mathbf{2 7}$ could be achieved in $9 \%$ yield when precursors $\mathrm{A}, \mathrm{B}$, and $\mathrm{C}$ interact at $6: 1: 2$ ratio. ${ }^{175}$ It is interesting to note that only the $\mathrm{ABAC}$ and $\mathrm{ACAC}$ compounds were observed in the product mixture in significant amounts and the target ABAC phthalocyanine $\mathbf{2 7}$ could easily be separated by chromatography (Scheme 11B). 
A)

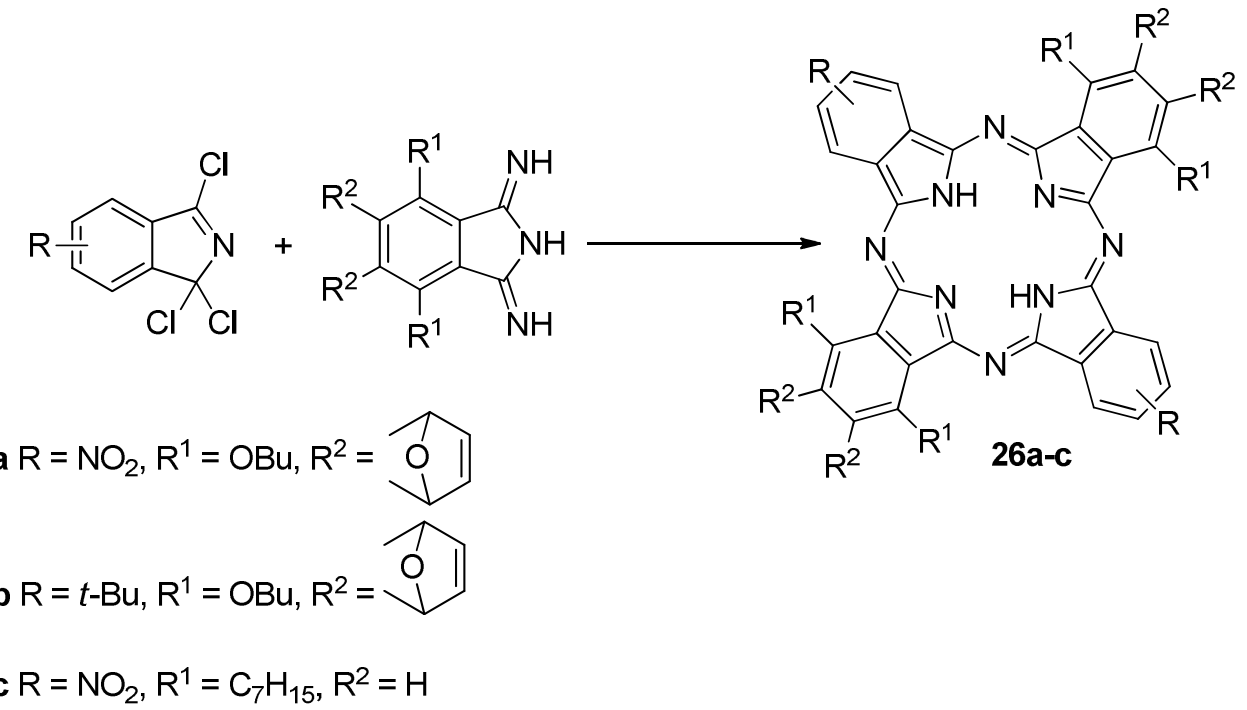

B)

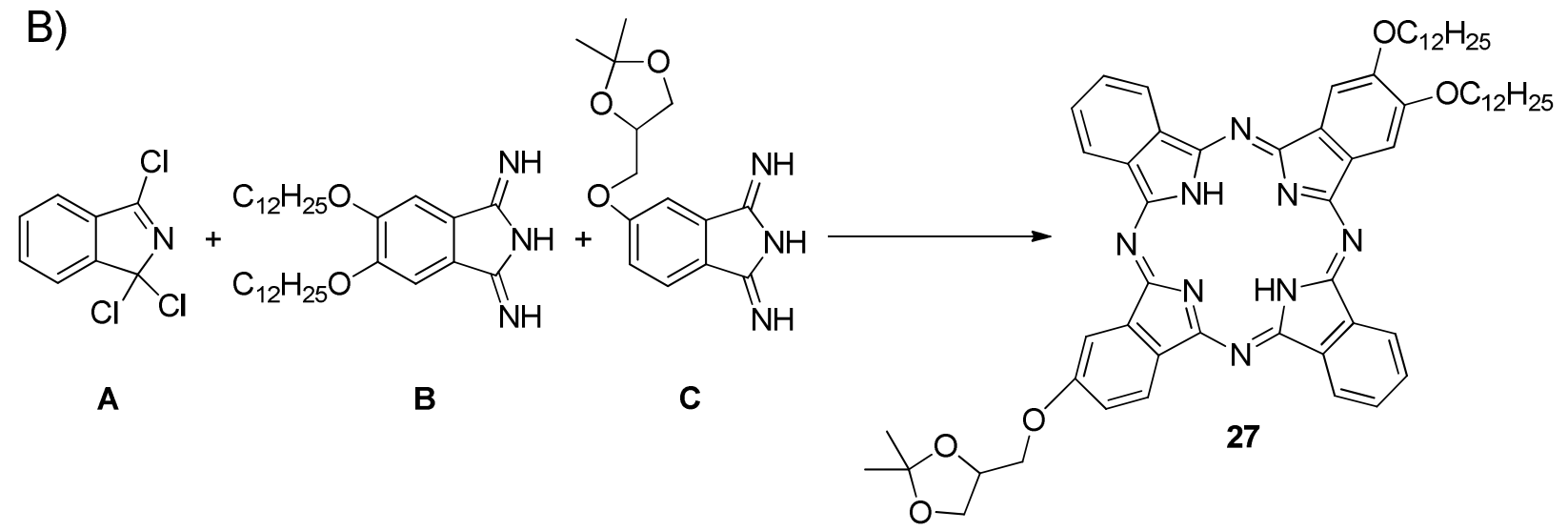

Scheme 11. Preparation of $A B A B$ and $A B A C$ phthalocyanines using a 1,1,3-trichloro-

$1 H$-isoindole.

In similar strategy, Leznoff and co-workers used cross condensation between a 1,3-diiminoisoindoline derivative and an isoindoline-1,3-dithione to form as target an opposite $\mathrm{ABAB}$ phthalocyanine 28d (Scheme 12). ${ }^{98}$ In this case, however, the authors observed formation of all six possible $\left(\mathrm{A}_{4}, \mathrm{~A}_{3} \mathrm{~B}, \mathrm{ABAB}, \mathrm{AABB}, \mathrm{AB}_{3}\right.$, and $\left.\mathrm{B}_{4}\right)$ products 28a-e, which is indicative of a scrambling reaction similar to that observed in the preparation of asymmetric porphyrin derivatives $^{176-179}$ as well as the reaction of subphthalocyanine with 1,3-diiminoisoindoles described later in this review. Because of such scrambling, the 1,3-diiminoisoindoline and isoindoline-1,3-dithione cross condensation route has no advantage over the more simple statistical condensation or 1,1,3-trichloro- $1 H$-isoindole strategies and is currently not in use by research groups. 


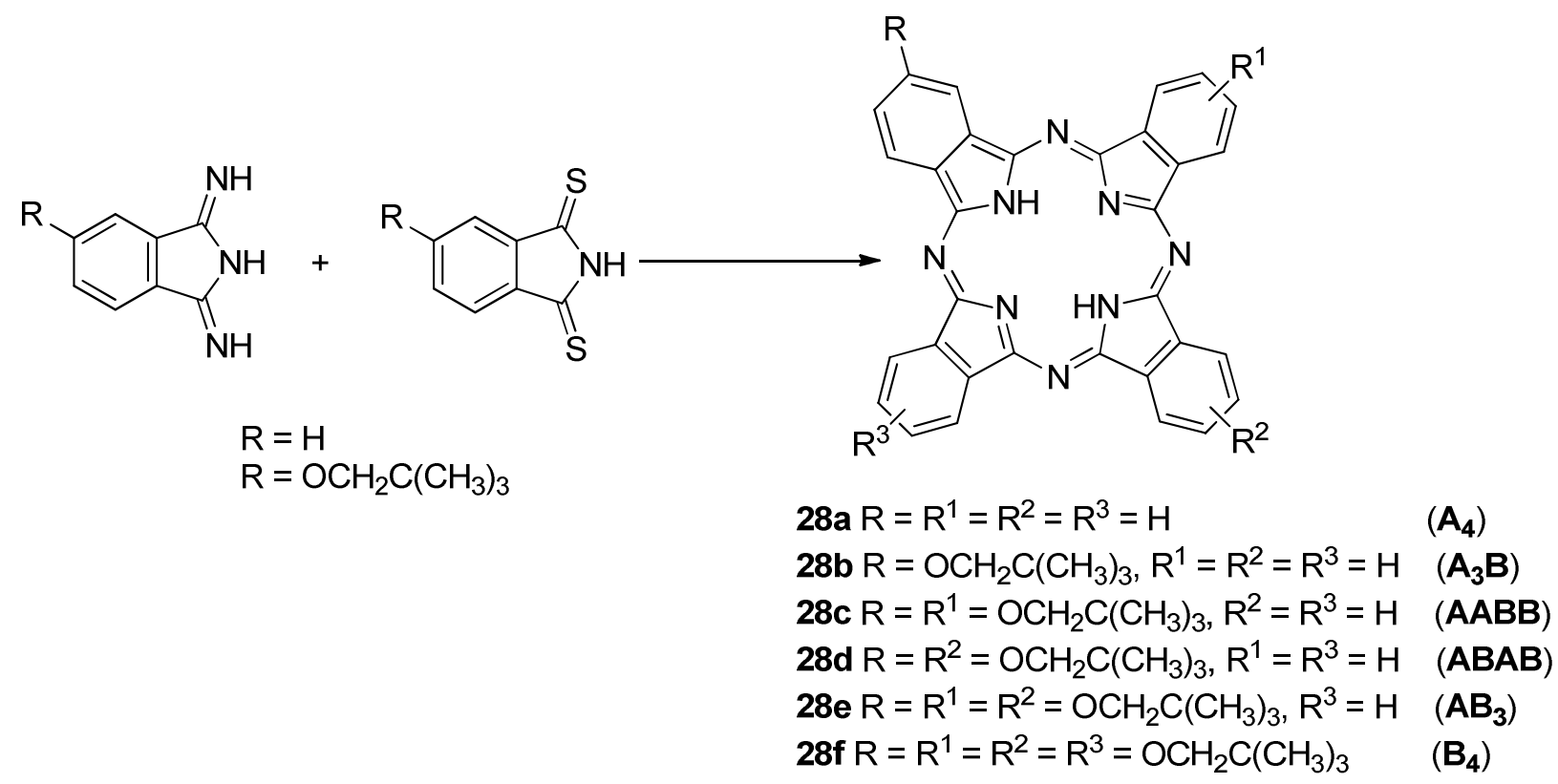

Scheme 12. Use of isoindoline-1,3-dithione in the preparation of asymmetric phthalocyanines.

\section{Targeted Synthesis of AABB-type Asymmetric Phthalocyanines from a Pre-formed AA-type Intermediate}

The "half-Pc" intermediate of AA type is another useful precursor for the preparation of asymmetric adjacent $\mathrm{AABB}$ phthalocyanines, which are difficult to prepare by the other synthetic methodologies and are promising candidates for non-linear optical applications. Formation of such intermediates was pioneered by Oliver and Smith at the end of the 1980s. ${ }^{180}$ Although these authors initially suggested that AA intermediates can only be formed from phthalonitriles with electron-withdrawing groups, several years later Leznoff and co-workers proved that the reaction between 4,5-bis-(3,3-dimethyl-1-butynyl)phthalonitrile with lithium methoxide in boiling methanol could also result in the formation of the desired AA compounds 29a-d (Scheme 13A). ${ }^{181}$ Moreover, Kobayashi and co-workers have shown that even the sterically demanding 3,6-diphenylphthalonitrile can form "half-Pc" intermediates under mild reaction conditions (Scheme 13B). ${ }^{182}$ In all cases, once formed, the "half-Pc" intermediate could be further reacted with a second phthalonitrile or its analogue to form the target AABB phthalocyanine as the major macrocyclic product. Although yields of AABB phthalocyanines can be quite high (around 20\%), some quantities of the other possible asymmetric and symmetric phthalocyanines were also observed in the reaction mixture and thus standard separation methods should be used for purification of the target material. 

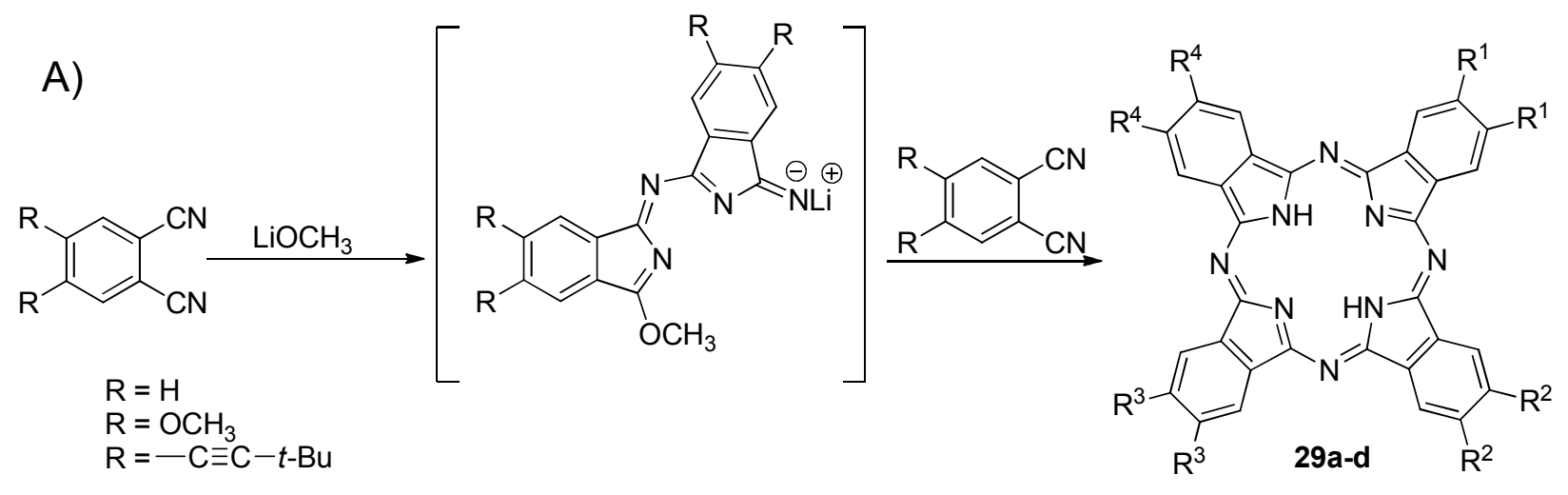

$$
\begin{aligned}
& \text { 29a } R^{1}=R^{2}=-C \equiv C-t-B u, R^{3}=R^{4}=H \\
& \text { 29b } R^{1}=-C \equiv C-t-B u, R^{2}=R^{3}=R^{4}=H \\
& \text { 29c } R^{1}=R^{2}=O C H_{3}, R^{3}=R^{4}=H \\
& \text { 29d } R^{1}=O C H_{3}, R^{2}=R^{3}=R^{4}=H
\end{aligned}
$$
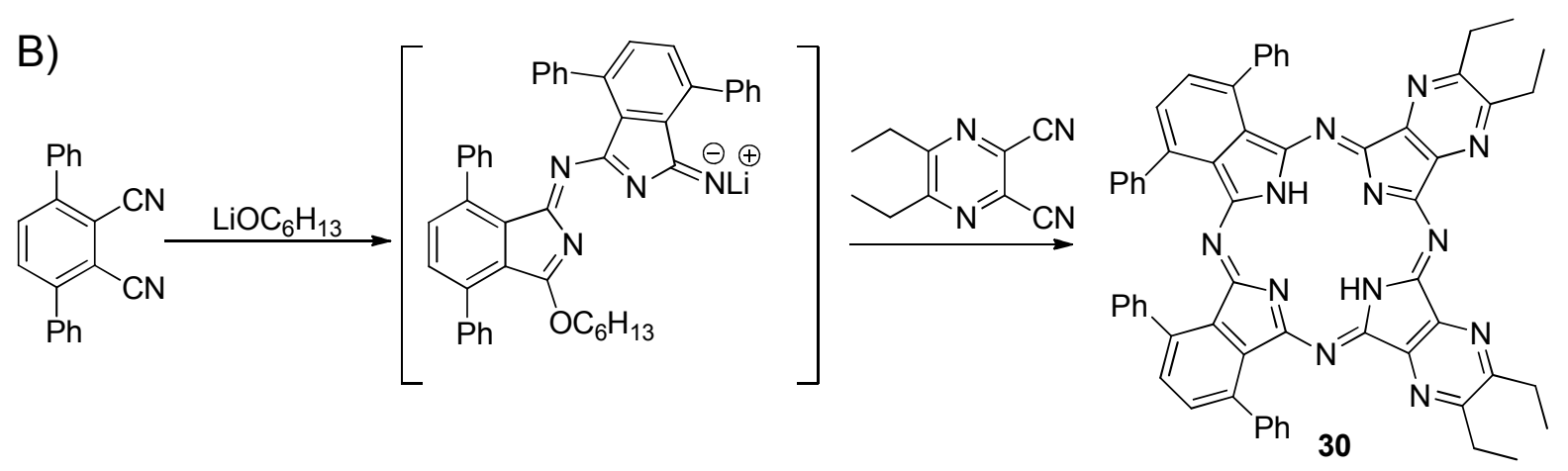

Scheme 13. Synthetic strategy for the selective preparation of AABB type asymmetric phthalocyanines using the "half-Pc" method.

\section{Subphthalocyanine Ring Expansion Strategy}

The smallest phthalocyanine analogues are subphthalocyanines (SubPcs), which have only three isoindole fragments with the tetrahedral boron as a central atom. ${ }^{183}$ These bowl-shaped aromatic macrocycles have effective $\mathrm{C}_{3 \mathrm{v}}$ symmetry and could be easily prepared by the reaction between substituted or unsubstituted phthalonitrile and $\mathrm{BX}_{3}(\mathrm{X}=\mathrm{F}, \mathrm{Cl}, \mathrm{Br})$. In 1988 and then in 1990, Ando and Mori ${ }^{99,184}$ as well as Kobayashi and co-workers in $1990^{100}$ found that SubPcs undergo ring expansion reaction when treated with 1,3-diaminoisoindoline or its analogues, resulting in the metal-free asymmetric $\mathrm{A}_{3} \mathrm{~B}$ phthalocyanines (Schemes 14-15). ${ }^{99,100,184-203}$ 
<smiles>[R]C1=C([R])C(=N)NC1=N</smiles>

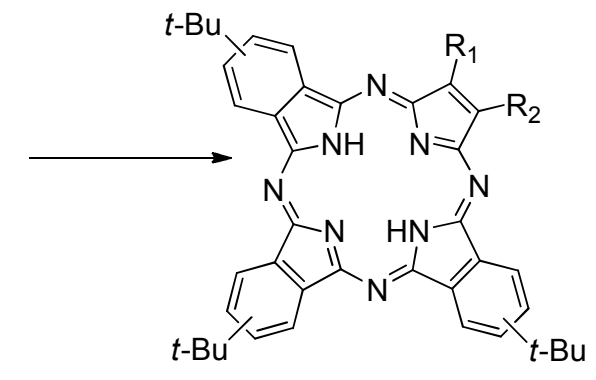

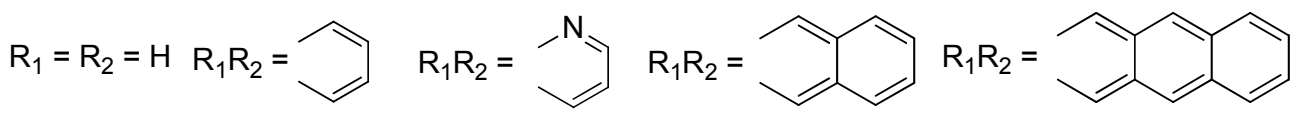<smiles>[R]CC1[Y]([R])=C2C(=N)NC(=N)C2=[Y]1C([R5])C</smiles><smiles>[R5][Y]1=C2C(C)=N/C(=N\c3[nH]c(C)c4cc([R3])c([R])c([R])c34)C2=[Y]([H])C1[R4]</smiles>

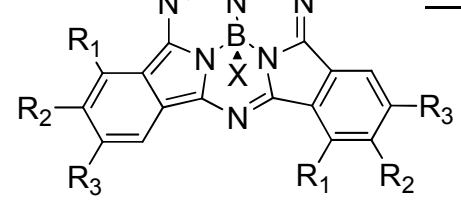

$R_{1}=R_{2}=R_{3}=H, R_{4}=R_{5}=O_{3} H_{7}, X=C l, Y=C H$

$R_{1}=R_{4}=R_{5}=H_{2}, R_{2}=R_{3}=I, X=B r, Y=C H$

$\mathrm{R}_{1}=\mathrm{R}_{3}=\mathrm{H}, \mathrm{R}_{2}=\mathrm{SO}_{3} \mathrm{H}, \mathrm{R}_{4}=\mathrm{R}_{5}=\mathrm{Ph}, \mathrm{X}=\mathrm{OH}, \mathrm{Y}=\mathrm{N}$

$R_{1}=R_{4}=R_{5}=H, R_{2}=R_{3}=S_{6} H_{13}, X=C l, Y=C_{2}$

$\mathrm{R}_{1}=\mathrm{R}_{5}=\mathrm{H}, \mathrm{R}_{2}=\mathrm{R}_{3}=\mathrm{SC}_{6} \mathrm{H}_{13}, \mathrm{R}_{4}=\mathrm{NO}_{2}, \mathrm{X}=\mathrm{Cl}, \mathrm{Y}=\mathrm{CH}_{2}$

$\mathrm{R}_{1}=\mathrm{H}, \mathrm{R}_{2}=\mathrm{R}_{3}=$

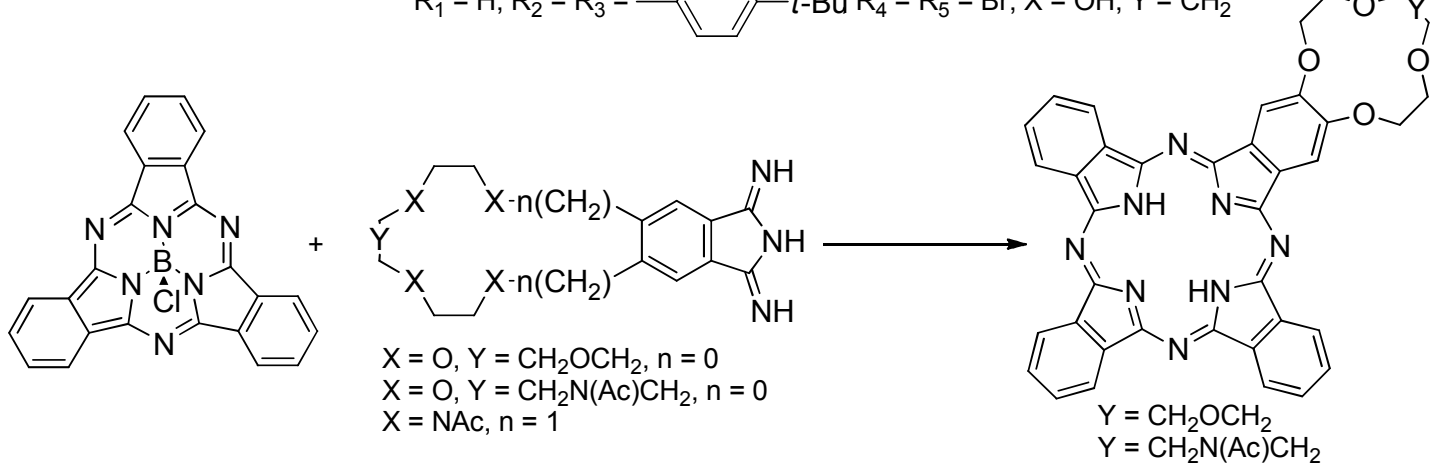

$\mathrm{X}=\mathrm{O}, \mathrm{Y}=\mathrm{CH}_{2} \mathrm{~N}(\mathrm{Ac}) \mathrm{CH}_{2}, \mathrm{n}=0$

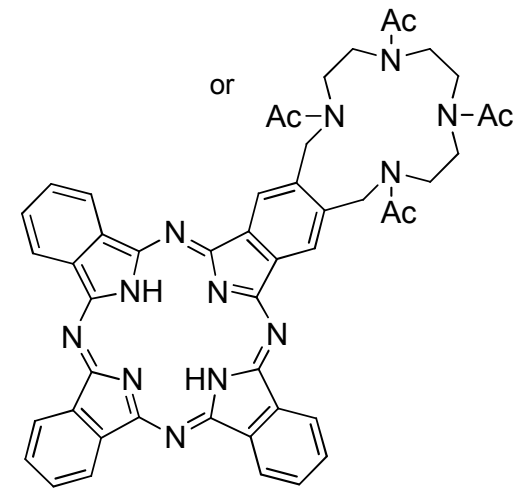

Scheme 14. Subphthalocyanine ring expansion strategy for the preparation of the metal-free $A_{3} B$ type asymmetric phthalocyanines. 


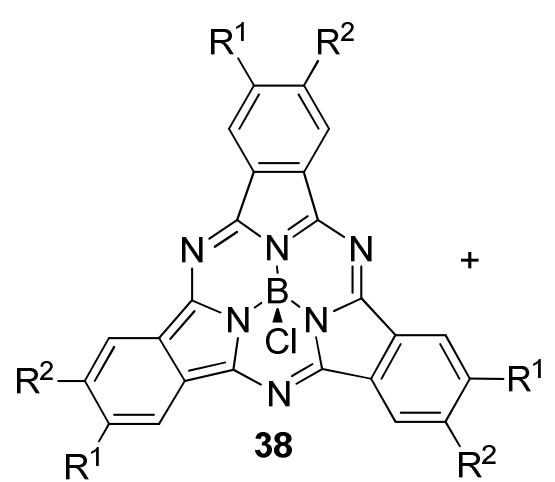

39a $\mathrm{R}^{1}=\mathrm{R}^{2}=\mathrm{R}^{4}=\mathrm{H}, \mathrm{R}^{3}=$

$39 b \mathrm{R}^{1}=\mathrm{R}^{2}=\mathrm{H}, \mathrm{R}^{3}=\mathrm{R}^{4}=-\mathrm{O}$

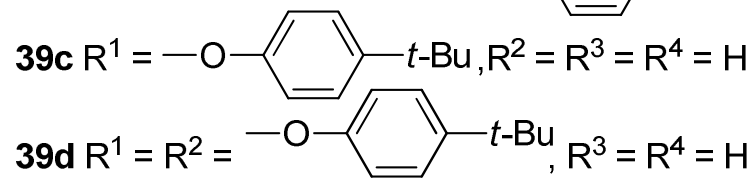

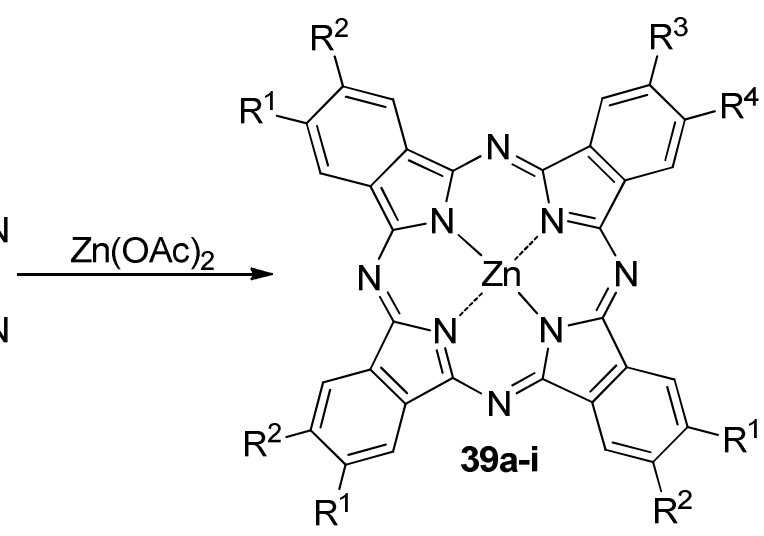

39e $\mathrm{R}^{1}=\mathrm{R}^{2}=\mathrm{R}^{3}=\mathrm{R}^{4}=$

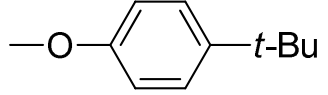

$39 f R^{1}=R^{2}=H, R^{3}=R^{4}=-O-C O O H$

39g $\mathrm{R}^{1}=\mathrm{R}^{2}=\mathrm{R}^{4}=\mathrm{H}, \mathrm{R}^{3}=\mathrm{NO}_{2}$

39h $\mathrm{R}^{1}=\mathrm{R}^{2}=\mathrm{H}, \mathrm{R}^{3}=\mathrm{R}^{4}=$<smiles>COc1ccc2ccccc2c1</smiles><smiles>[R]C=[R]=C=C[R3]#COc1ccc(C(C)(C)C)cc1</smiles>

Scheme 15. Subphthalocyanine ring expansion strategy for the preparation of zinc $A_{3} B$ type asymmetric phthalocyanines

Based on chemical kinetic data gained by UV-vis spectroscopy, the SubPc ring expansion reaction is a first-order reaction with respect to SubPc. ${ }^{188,195}$ The proposed reaction mechanism requires the cleavage of the SubPc ring, extrusion of the central boron atom, and further cyclization of the resulting open phthalonitrile trimer with the available 1,3-diiminiisoindoline. One of the initial reports ${ }^{100}$ claimed that such a ring expansion reaction is highly selective and the asymmetric $\mathrm{A}_{3} \mathrm{~B}$ phthalocyanine is the only major product. It was soon realized, however, that the reaction selectivity is highly dependent on the reaction conditions, the nature of the solvent(s), the structure of the SubPc, and the electronic properties of the 1,3-diiminoisoindolines. Indeed, in some cases it was found that the ring expansion reaction is highly selective and the yield of pure $\mathrm{A}_{3} \mathrm{~B}$ phthalocyanine could be as high as $90 \%,{ }^{100}$ while other research groups found by HPLC and other spectroscopic methods that this synthetic strategy leads to the formation of all possible reaction products $\left(\mathrm{A}_{4}, \mathrm{~A}_{3} \mathrm{~B}, \mathrm{AABB}, \mathrm{ABAB}, \mathrm{AB}_{3}\right.$, and $\left.\mathrm{B}_{4}\right){ }^{204}$ On this basis, it was suggested that once the SubPc ring is cleaved, the resulting open-chain AAA trimer undergoes a scrambling reaction followed by statistical condensation between available subunits, which results in the formation of all the observed products. Several research groups have found that the ring expansion reaction selectivity towards the formation of an $A_{3} B$ phthalocyanine could be improved by the following factors. ${ }^{67}$ Firstly, the best yields of a desired $\mathrm{A}_{3} \mathrm{~B}$ compound 
could be achieved when the SubPc macrocycle has electron-withdrawing substituents or no substituents, and the 1,3-diiminoisoindoline reactant has electron-donating groups. Secondly, when SubPcs reacted with the lower-activity phthalonitrile (instead of a 1,3-diiminoisoindoline) and a strong base (DBU), the yields and selectivity of formation of $\mathrm{A}_{3} \mathrm{~B}$ phthalocyanines are quite good. ${ }^{204}$ Finally, when zinc $\mathrm{A}_{3} \mathrm{~B}$ phthalocyanines are the target, they could be prepared in reasonable yield and selectivity when SubPcs are treated with the corresponding phthalonitriles in the presence of a zinc salt (Scheme 15). ${ }^{204}$

In general, when the target asymmetric phthalocyanine is of $\mathrm{A}_{3} \mathrm{~B}$ type, the SubPc ring expansion reaction is as popular these days as the statistical condensation method. Yields of $\mathrm{A}_{3} \mathrm{~B}$ phthalocyanines in both methods are similar, and several SubPc precursors are currently commercially available, which obviates an additional synthetic step in ring expansion synthetic strategy. Another advantage of the SubPc method is obvious when one needs to prepare $\mathrm{A}_{3} \mathrm{~B}$ phthalocyanine with A fragments of low solubility (i.e. when only $\mathrm{C}-\mathrm{H}$ or $\mathrm{C}$-halogen bonds are present). In this case the statistical condensation reaction tends to give $A_{4}$ and $A_{3} B$ mixtures, which, because of strong intermolecular aggregation, is very difficult to separate by conventional purification methods. ${ }^{67}$ On the other hand, both unsubstituted and dodecahalo SubPcs are quite soluble precursors, and if the ring expansion reaction conditions are optimized to give the $\mathrm{A}_{3} \mathrm{~B}$ phthalocyanine as the main or only reaction product, purification of the target compound is not a problem.

\section{Post-modification of Pre-formed Macrocycles}

Asymmetric phthalocyanines and their analogues can also be prepared using symmetric or asymmetric phthalocyanines using a variety of synthetic strategies. Such transformations are discussed in this part of the review.

\subsection{Cycloaddition reactions}

Hanack and co-workers have pioneered the use of the oxygen-bridged bicyclic asymmetric phthalocyanines 26 and 42 in cycloaddition reactions (Schemes 16, 17). ${ }^{167,168,205-208}$ Such phthalocyanines easily form Diels-Alder reaction products when reacted as dienophiles under mild conditions with different dienes. When tetraphenylcyclodienone is used in reaction with asymmetric phthalocyanine 26a, thermal decomposition of the reaction product $\mathbf{4 0}$ in situ generates the furan-substituted phthalocyanine intermediates 40a, which could be used as dienes in further Diels-Alder reactions with bicyclic dienophiles to form ladder-type oligomers 41 incorporating phthalocyanine units (Scheme 16). The asymmetric bicyclic diene-containing phthalocyanine 45 could be further reacted with fullerene to form cycloaddition fullerenecontaining phthalocyanine analogue 46 (Scheme 18). ${ }^{209}$ Similarly, Kobayashi and co-workers used Diels-Alder reaction between $\mathrm{C}_{60}$ and diene prepared in situ from phthalocyanine-4,5diazine to form covalent phthalocyanine : $\mathrm{C}_{60}$ adduct. ${ }^{210}$ In another interesting reaction, Hanack 
and team found that the oxygen-bridged phthalocyanine 42e could undergo cycloaddition reactions with substituted pyridine oxides to form the heterocyclic adducts $\mathbf{4 7 a - c}$ (Scheme 19). ${ }^{211}$

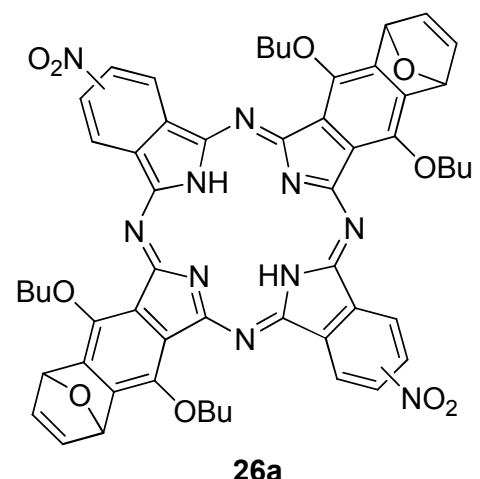

26a

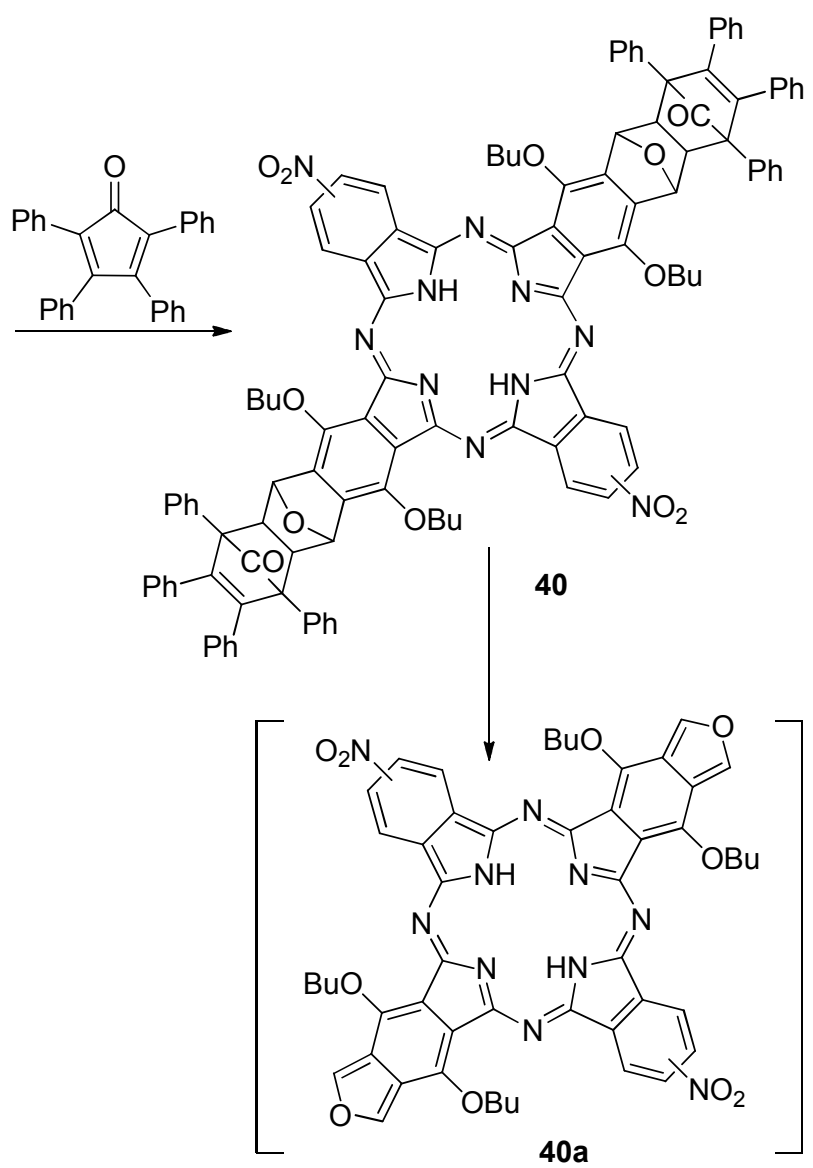

40a

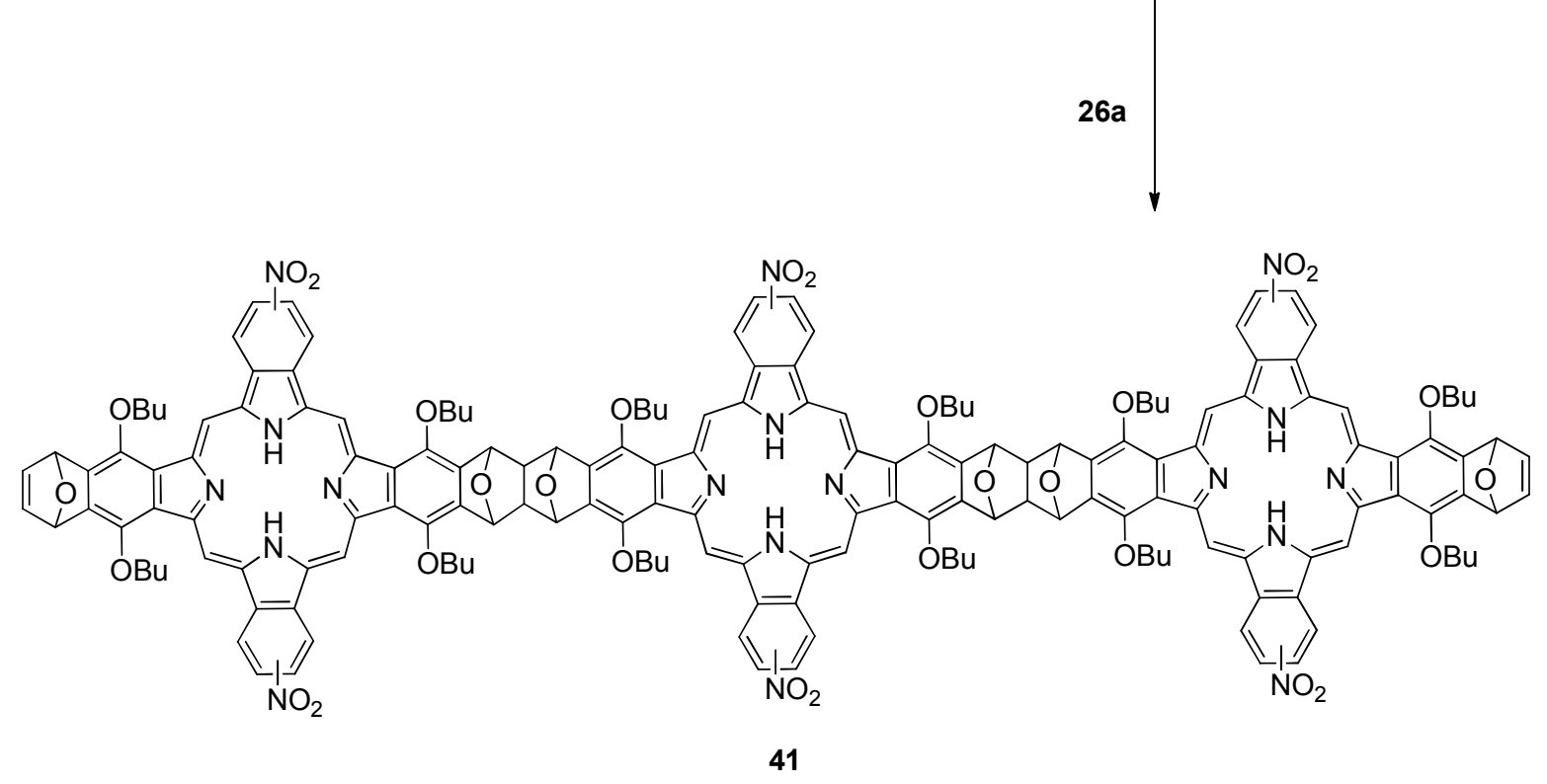

Scheme 16. Use of the Diels-Alder reaction in the preparation of "ladder" type asymmetric phthalocyanines. 


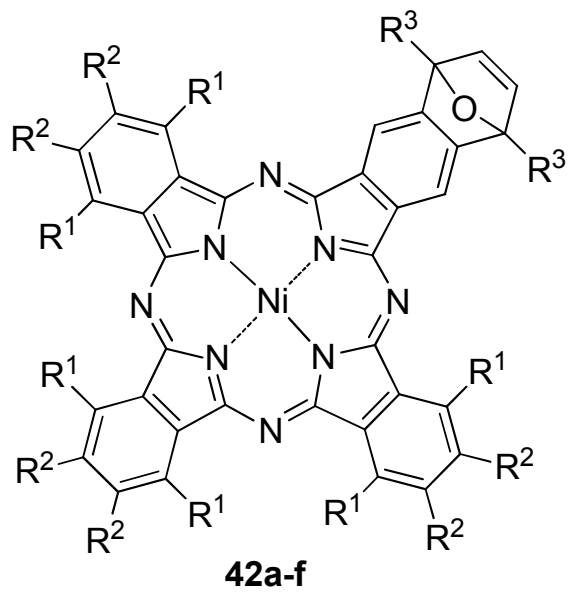<smiles>O=C1C(c2ccccc2)=C(c2ccccc2)C(c2ccccc2)=C1c1ccccc1</smiles>

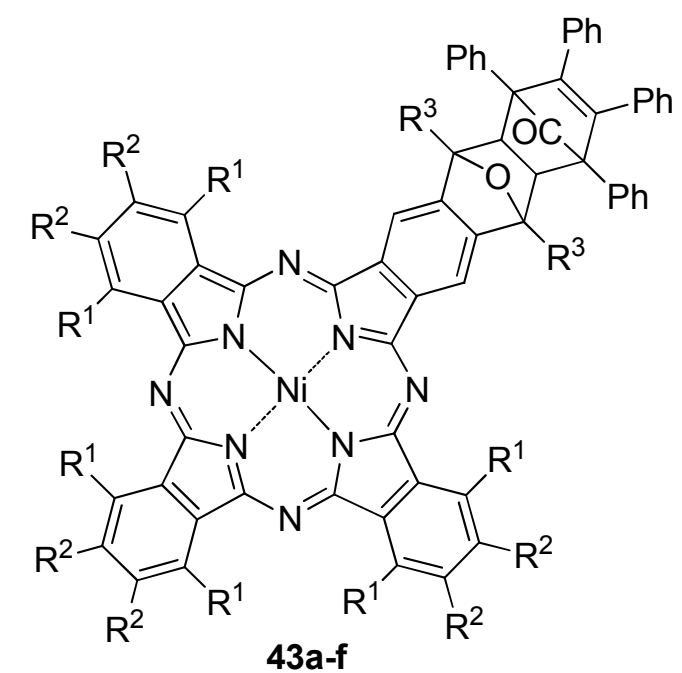

$$
\begin{aligned}
& \text { 42a, 43a } R^{1}=\mathrm{OC}_{4} \mathrm{H}_{9}, \mathrm{R}^{2}=\mathrm{H}, \mathrm{R}^{3}=\mathrm{H} \\
& \text { 42b, 43b } \mathrm{R}^{1}=\mathrm{H}, \mathrm{R}^{2}=\mathrm{OC}_{8} \mathrm{H}_{17}, \mathrm{R}^{3}=\mathrm{H} \\
& \text { 42c, 43c } \mathrm{R}^{1}=\mathrm{H}, \mathrm{R}^{2}=\mathrm{OC}_{10} \mathrm{H}_{21}, \mathrm{R}^{3}=\mathrm{H} \\
& \text { 42d, 43d } \mathrm{R}^{1}=\mathrm{H}, \mathrm{R}^{2}=\mathrm{CH}_{3} \mathrm{CH}\left(\mathrm{C}_{2} \mathrm{H}_{5}\right)\left(\mathrm{CH}_{2}\right)_{3} \mathrm{CH}_{3}, \mathrm{R}^{3}=\mathrm{H} \\
& \text { 42e, 43e } \mathrm{R}^{1}=\mathrm{H}, \mathrm{R}^{2}=\mathrm{OCH}_{2} \mathrm{CH}\left(\mathrm{C}_{2} \mathrm{H}_{5}\right)\left(\mathrm{CH}_{2}\right)_{3} \mathrm{CH}_{3}, \mathrm{R}^{3}=\mathrm{CH}_{3} \\
& \text { 42f, 43f } \mathrm{R}^{1}=\mathrm{R}^{2}=\mathrm{OCH}_{2} \mathrm{CH}\left(\mathrm{C}_{2} \mathrm{H}_{5}\right)\left(\mathrm{CH}_{2}\right)_{3} \mathrm{CH}_{3}, \mathrm{R}^{3}=\mathrm{CH}_{3}
\end{aligned}
$$

Scheme 17. Diels-Alder reactions in the preparation of $A_{3} B$ type asymmetric phthalocyanines.

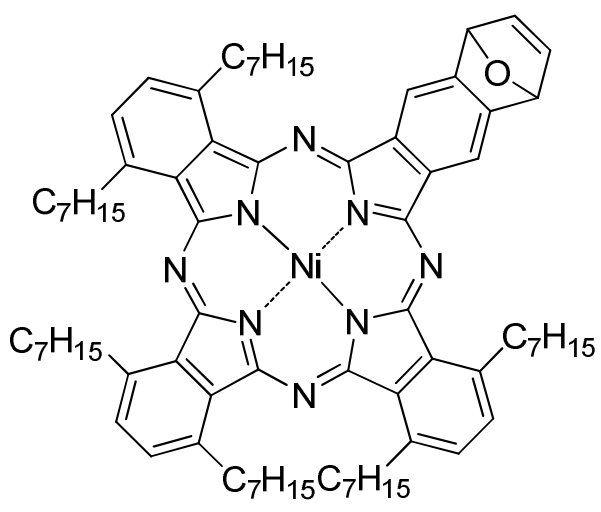

44
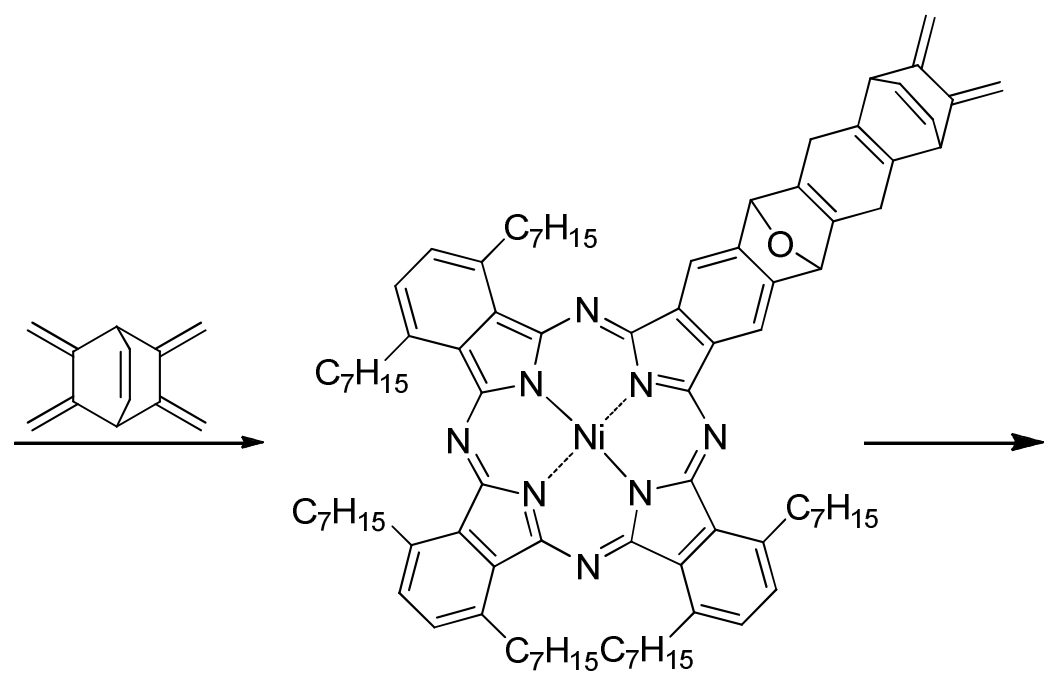

45 
45
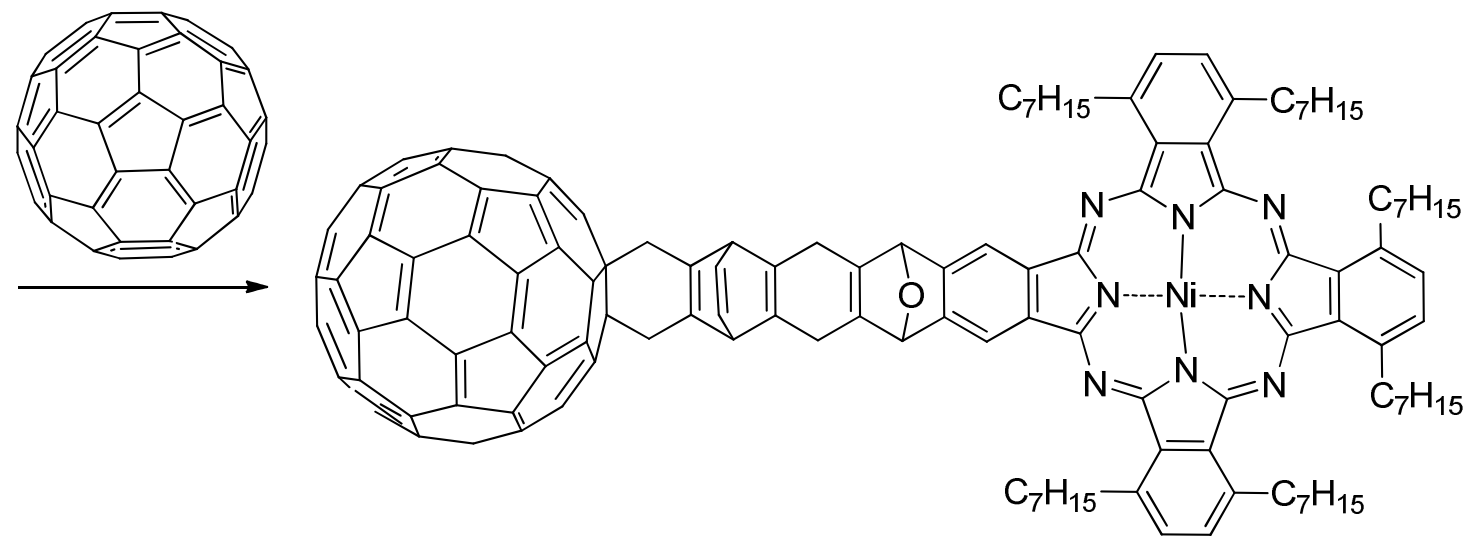

46

Scheme 18. Formation of the $A_{3} B$ type phthalocyanine: $C_{60}$ adduct using the Diels-Alder reaction.
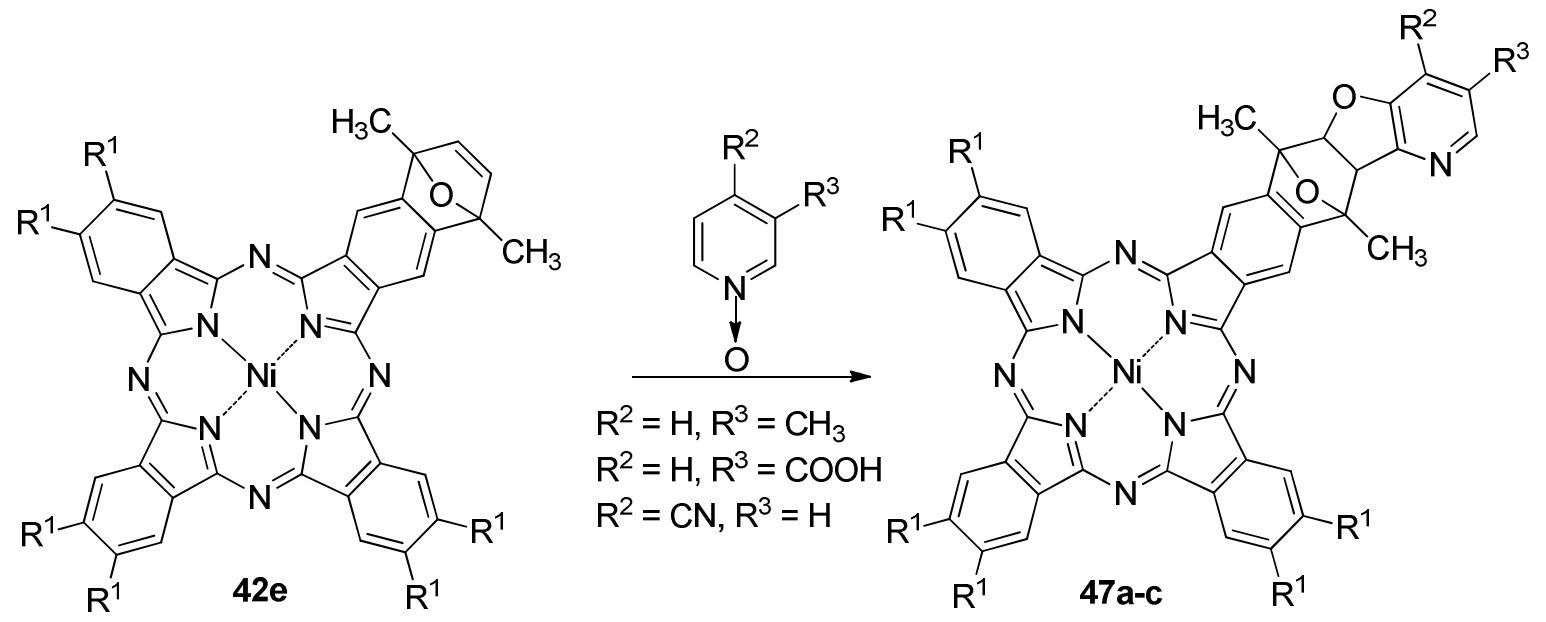

$$
\begin{aligned}
& \text { 47a R } \mathrm{R}^{1}=\mathrm{OCH}_{2} \mathrm{CH}\left(\mathrm{C}_{2} \mathrm{H}_{5}\right)\left(\mathrm{CH}_{2}\right)_{3} \mathrm{CH}_{3}, \mathrm{R}^{2}=\mathrm{H}, \mathrm{R}^{3}=\mathrm{CH}_{3} \\
& \text { 47b R } \mathrm{R}^{1}=\mathrm{OCH}_{2} \mathrm{CH}\left(\mathrm{C}_{2} \mathrm{H}_{5}\right)\left(\mathrm{CH}_{2}\right)_{3} \mathrm{CH}_{3}, \mathrm{R}^{2}=\mathrm{R}^{3}=\mathrm{H} \\
& \text { 47c R } \mathrm{R}^{1}=\mathrm{OCH}_{2} \mathrm{CH}\left(\mathrm{C}_{2} \mathrm{H}_{5}\right)\left(\mathrm{CH}_{2}\right)_{3} \mathrm{CH}_{3}, \mathrm{R}^{2}=\mathrm{CN}, \mathrm{R}^{3}=\mathrm{H}
\end{aligned}
$$

Scheme 19. Use of pyridine $N$-oxides in cycloaddition reactions for the preparation of $\mathrm{A}_{3} \mathrm{~B}$ type asymmetric phthalocyanines.

Thiophene-containing phthalocyanine analogues are less explored in cycloaddition reactions compared to the above discussed asymmetric furan systems studied by Hanack and co-workers. Indeed, only one report is available on the Diels-Alder reaction between an $A_{3} B$ type thiophenecontaining system 48 with dimethyl acetylenedicarboxylate (DMAD). An initial tribenzotetraazachlorin-type DMAD adduct 48a could be transformed into an $\mathrm{A}_{3} \mathrm{~B}$ phthalocyanine ester 49 by simple heating of the reaction mixture (Scheme 20). ${ }^{212}$ 


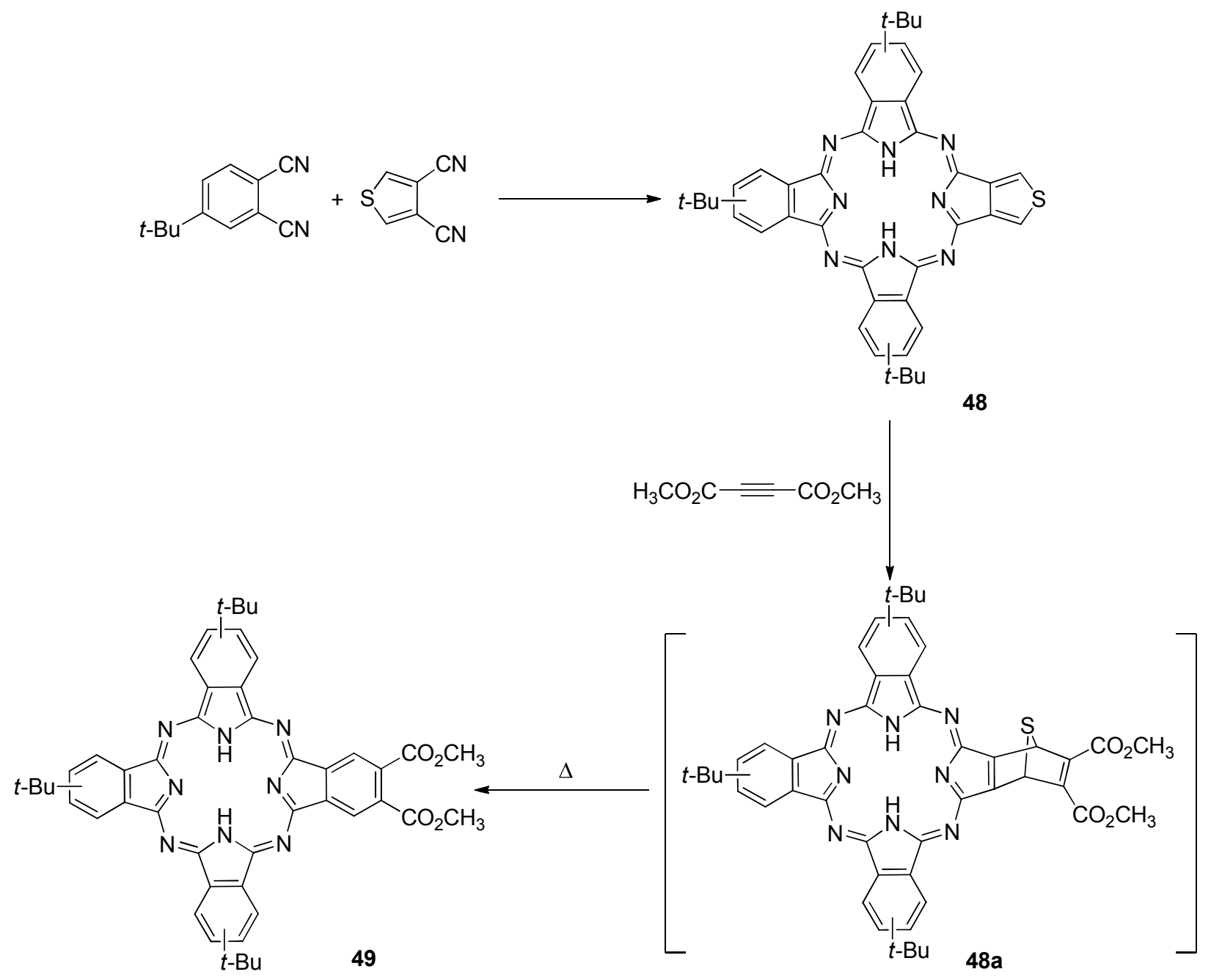

Scheme 20. Use of the thiophene-containing phthalocyanine analogue for the preparation of an $\mathrm{A}_{3} \mathrm{~B}$ type asymmetric phthalocyanine.

Luk'yanets and co-workers have shown that the unsubstituted porphyrazines (TAPs) could be used as dienophiles in Diels-Alder or [3+2] cycloaddition reactions with a variety of reactants. $^{213-216}$ Depending on the reaction temperature and the nature of the diene, tetraazachlorins (TACs), tetraazabacteriochlorins (TABs), and tetraazaisobacteriochlorins (TAiBs) could be isolated from the reaction mixture (Schemes 21, 22). ${ }^{213-215}$ For instance, the Diels-Alder reaction between unsubstituted porphyrazine $\mathbf{5 0}$ and anthracene derivatives at $130^{\circ} \mathrm{C}$ results in the selective formation of tetraazachlorins $\mathbf{5 1}$, while raising the reaction temperature leads to the formation of tetraazabacteriochlorins $\mathbf{5 2}$ and tetraazaisobacteriochlorins $\mathbf{5 3}$ as the major products (Scheme 21); ${ }^{213}$ similar results were obtained in the cyclopentadiene series. ${ }^{216}$ Similarly, [3+2] cycloaddition reaction between tetraazaporphyrins 50, 54 or 56 and generated in situ dipolar reactants results in formation of respective tetraazachlorins $\mathbf{5 5}, \mathbf{5 7}$, or $\mathbf{5 9}$ along with tetraazabacteriochlorins 60 and 61 or tetraazaisobacteriochlorin 58 (Scheme 22). Of course, in 
the case of tribenzotetraazaporphyrin 54, the [3+2] cycloaddition reaction selectively leads to the formation of the tetraazachlorin derivative $\mathbf{5 5}$.

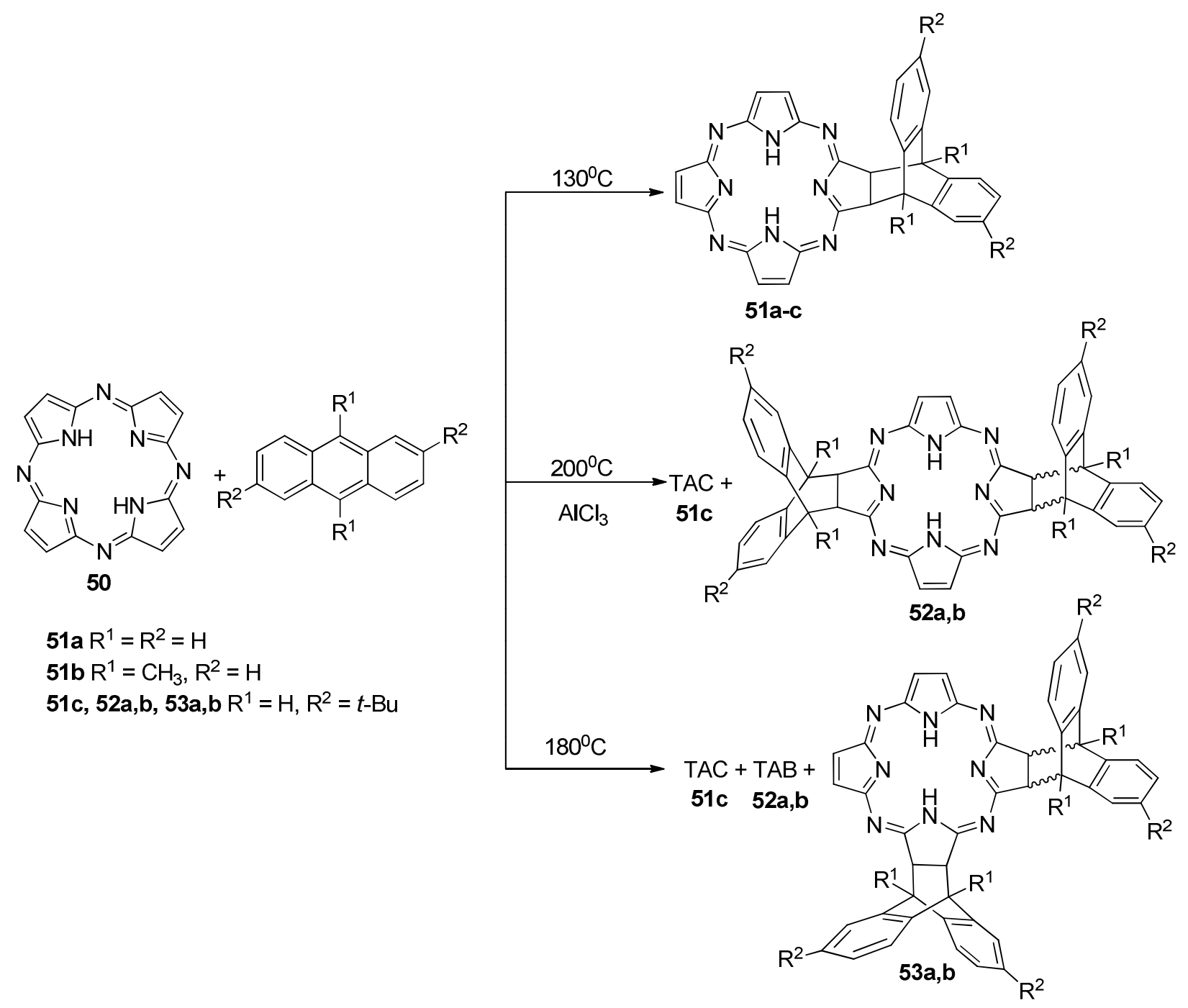

Scheme 21. Preparation of tetraazachlorins, tetraazabacteriochlorins, and tetraazaisobacteriochlorins using the Diels-Alder reaction. 

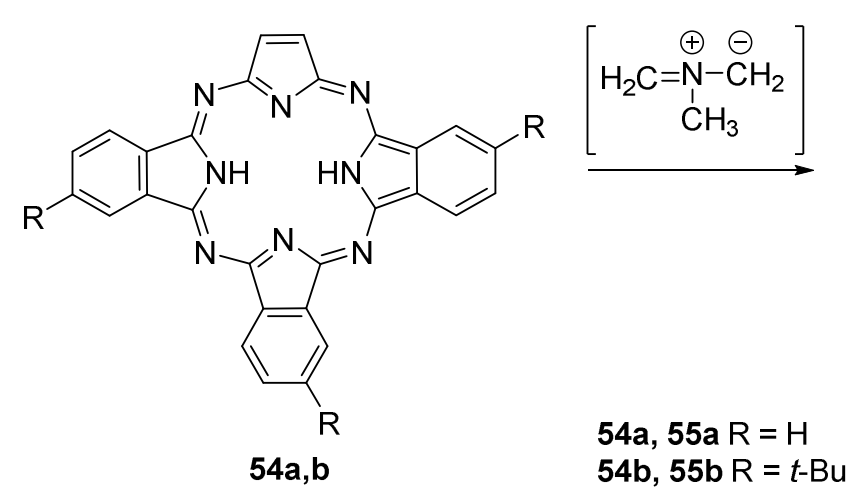

$54 a, 55 a \mathrm{R}=\mathrm{H}$

$54 \mathrm{~b}, 55 \mathrm{~b} \mathrm{R}=t-\mathrm{Bu}$

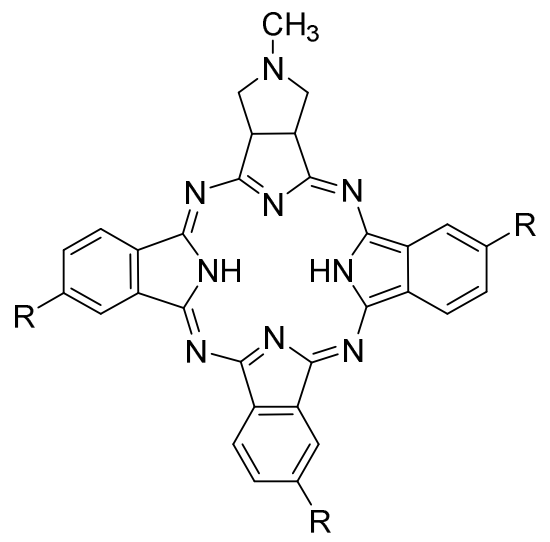

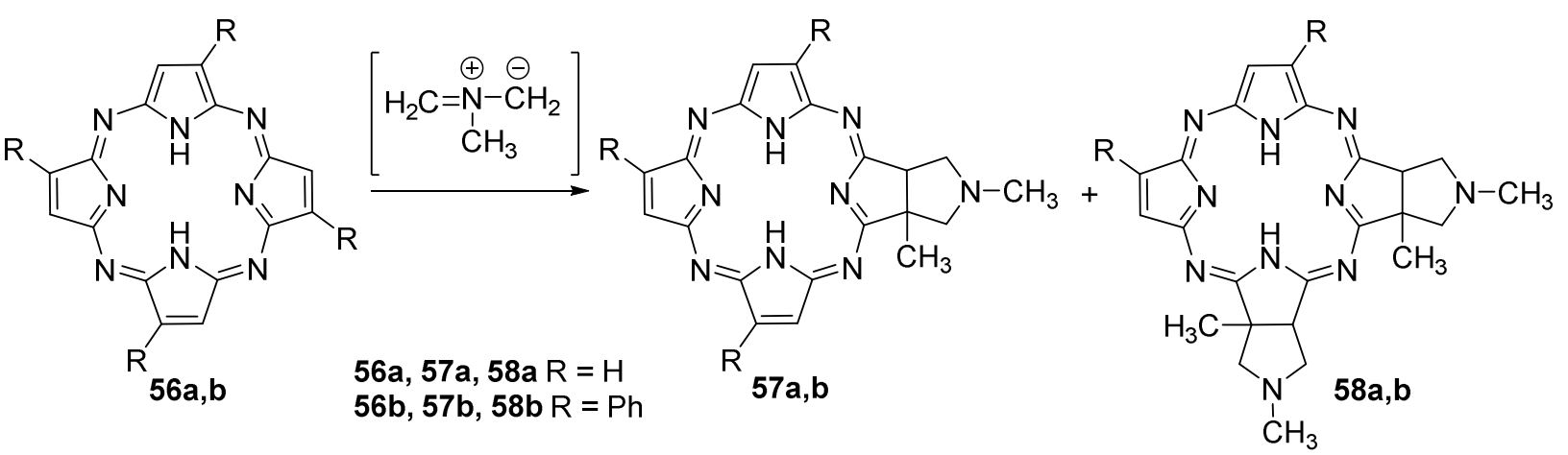<smiles></smiles>

50

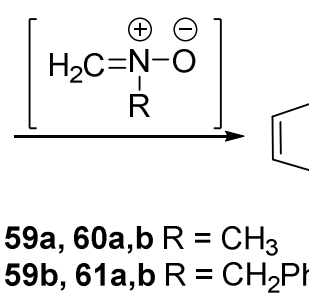

$59 b, 61 a, b \mathrm{R}=\mathrm{CH}_{2} \mathrm{Ph}$<smiles></smiles>

$59 a, b$<smiles>[R][NH+]1CC2C(=N)N=C(N)C2O1</smiles>

(1)

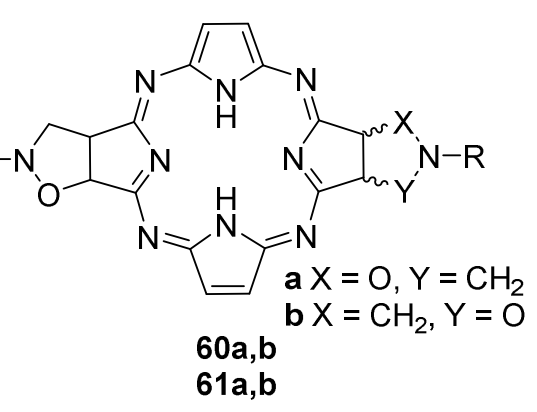

Scheme 22. Using of the [3+2] cycloaddition reaction for preparation of tetraazachlorins, tetraazabacteriochlorins, and tetraazaisobacteriochlorins.

\subsection{Cross-coupling approach}

The Suzuki, Sonogashira, Heck, Buchwald, and related coupling reactions have become very popular as a universal synthetic approach for the selective transformation of asymmetric phthalocyanines over the past few decades (Schemes 23, 24 and Figures 4, 5). ${ }^{217-243}$ In particular, as shown in the laboratories of Torres, van Lier, and many others, the mono-iodo $A_{3} B$ phthalocyanines 62 can easily be made to undergo a variety of coupling reactions (Scheme 23). ${ }^{218,220,221,223,227,228,236-242}$ This precursor can be used for the introduction of direct carboncarbon bonds as aryl, alkenyl, and alkynyl substituents. ${ }^{21,219,220,226,234,235}$ In addition, the Buchwald reaction can be used for carbon-nitrogen bond formation. ${ }^{218,220,223}$ 


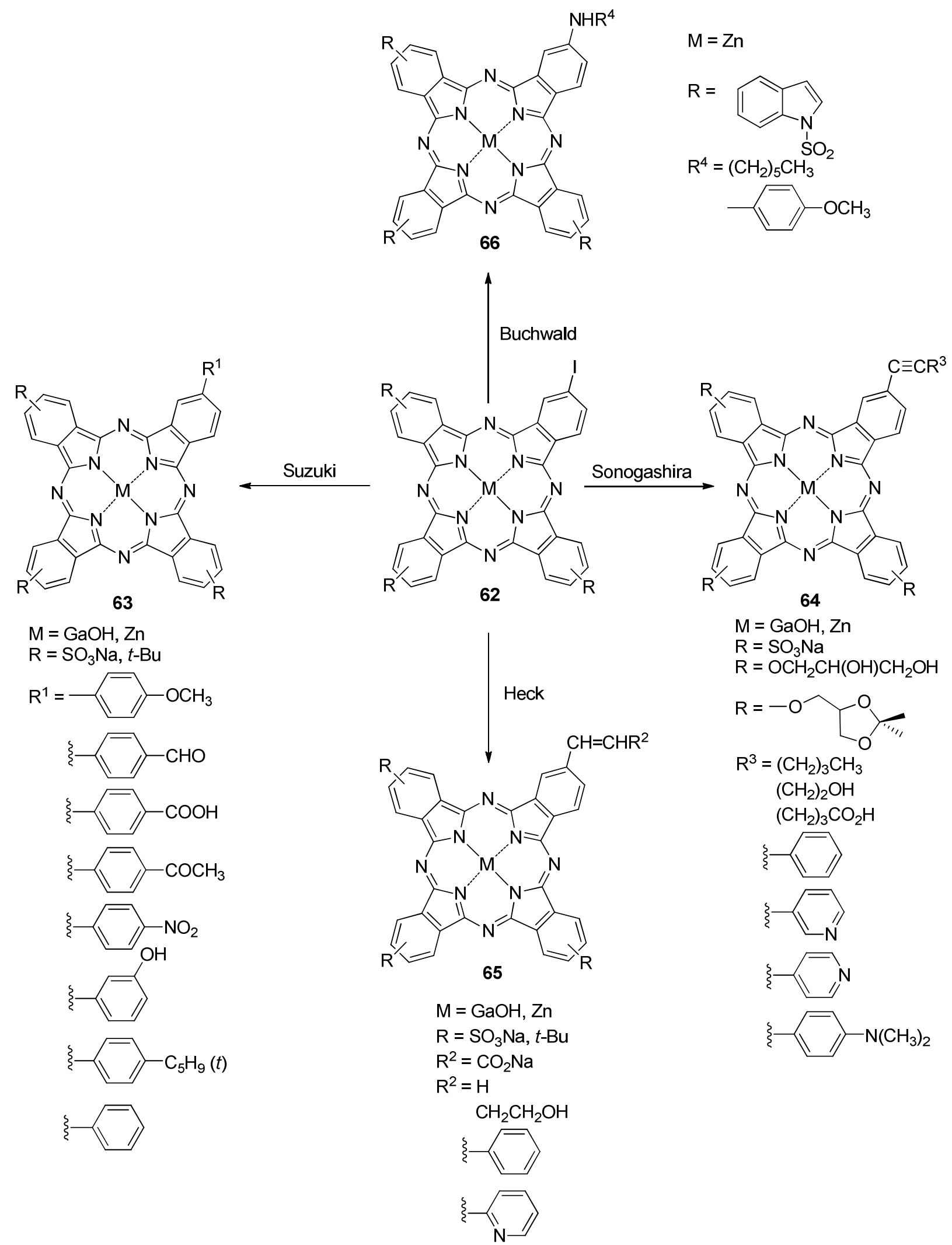

Scheme 23. General strategy for the peripheral modification of asymmetric phthalocyanines using coupling reactions. 


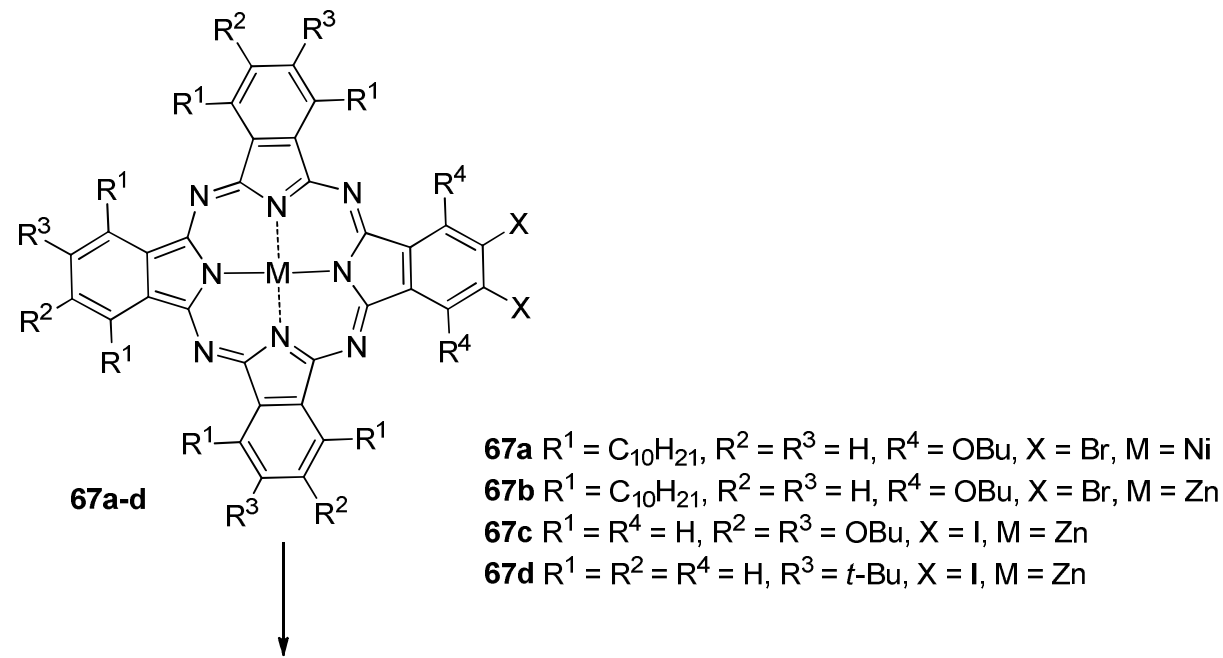

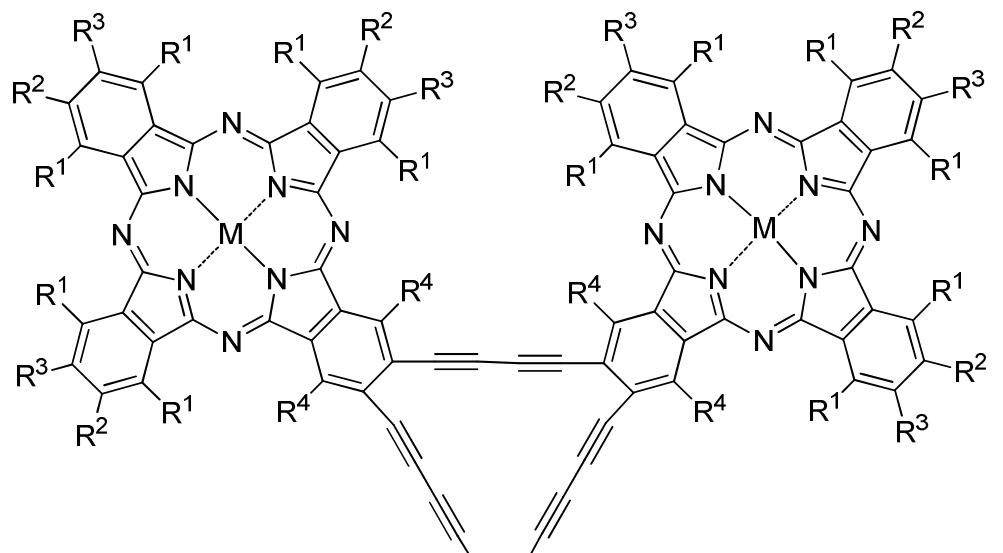

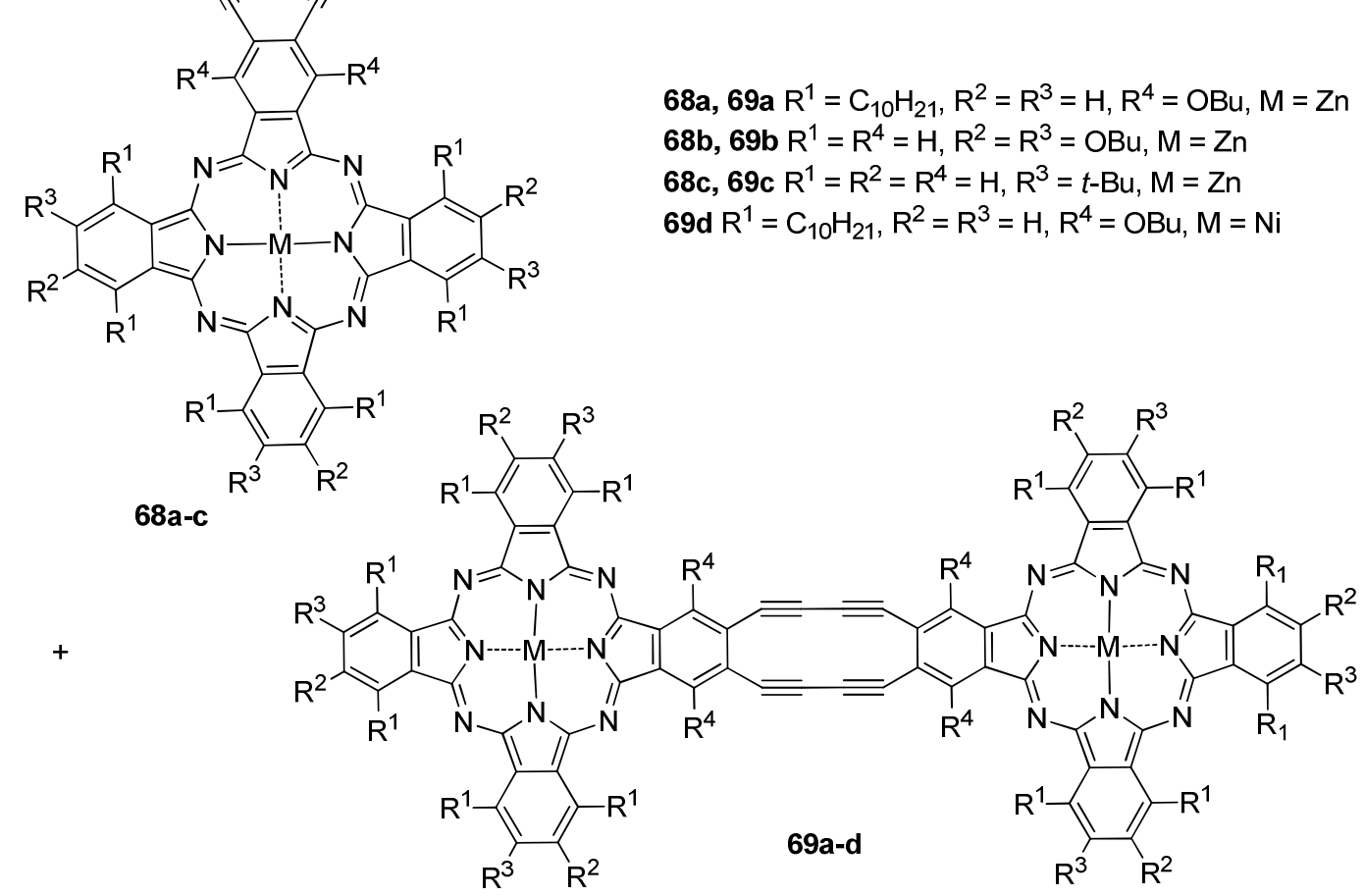

Scheme 24. General strategy for the formation of cyclic phthalocyanine dimers and trimers using Glaser and Eglinton reactions. 


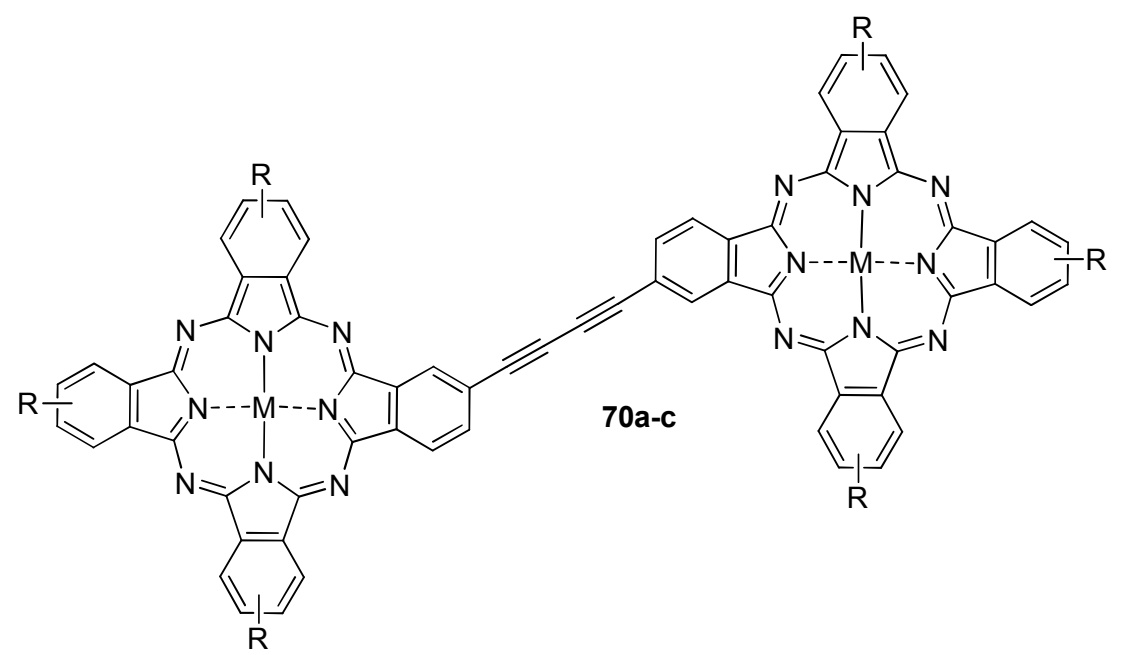

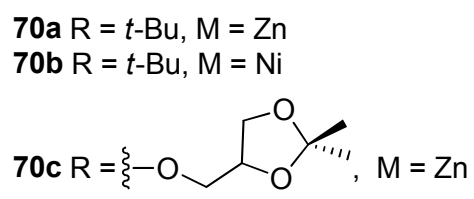<smiles>C[R11](C)(C)C(C)(C)C</smiles>

Figure 4. Representative examples of dimeric phthalocyanines prepared using coupling reactions with the incorporation or formation of carbon-carbon triple and double bonds.

Palladium-catalyzed coupling of the mono-iodo $\mathrm{A}_{3} \mathrm{~B}$ phthalocyanine $\mathbf{6 2}$ with trimethylsilylacetylene forms an ethynyl-containing phthalocyanine, which can be deprotected under basic conditions to give the phthalocyanine $\mathbf{7 3}$ (Scheme 25) containing a highly reactive terminal C-H 
bond. $^{218,223}$ A similar result could be achieved by direct introduction of the alkynyl fragment using Stille coupling between the halogen-containing $\mathrm{A}_{3} \mathrm{~B}$ phthalocyanine $\mathbf{6 2}$ and tributylstannylacetylene. ${ }^{218}$ Asymmetric $\mathrm{A}_{3} \mathrm{~B}$ phthalocyanines with one or two terminal acetylene substituents are excellent precursors to binuclear ethyne-bridged phthalocyanines 70-72 (Figure 4). ${ }^{217,219,226,230}$ In the simplest case, a monoacetylene-substituted phthalocyanine was coupled with the mono iodo-substituted phthalocyanine, giving the ethyne-bridged binuclear compound 70 (Figure 5). ${ }^{217,219}$ Another interesting example, which follows a similar synthetic strategy, couples an $\mathrm{A}_{3} \mathrm{~B}$ type monoiodo-containing phthalocyanine with a monoprotected DEEcontaining $\mathrm{A}_{3} \mathrm{~B}$ phthalocyanine to form (E)-1,2-diethynylethene-bridged binuclear phthalocyanine $\mathbf{7 1}$ in which each phthalocyanine fragment could have different central metal and different peripheral substituents (Figure 4). ${ }^{226}$ Torres' and Cook's research groups utilized Glaser and Eglinton reactions for the preparation of cyclic binuclear and trinuclear diyne-bridged phthalocyanines 68 and 69 (Scheme 24). ${ }^{224,225,229}$ In this case, dihalo $\mathrm{A}_{3} \mathrm{~B}$ type phthalocyanines 67 with neighboring halogen atoms were coupled with the alkyne fragments using a palladiumcatalyzed reaction. Once transformed into acetylene-containing compounds with terminal $\mathrm{C}-\mathrm{H}$ bonds, they undergo self-condensation to form cyclic binuclear or trinuclear compounds.
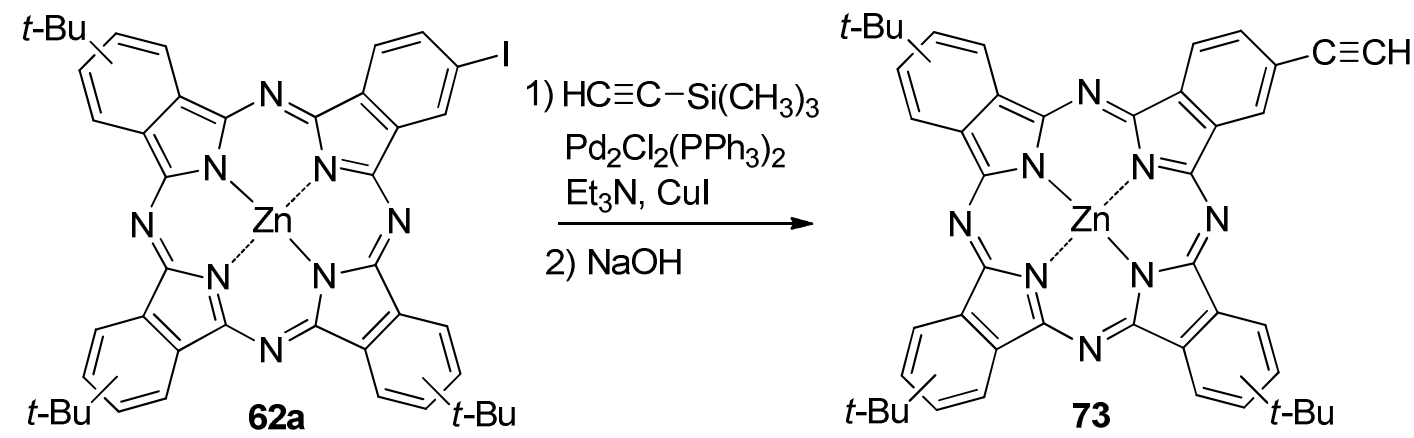

Scheme 25. Standard approach for the preparation of asymmetric phthalocyanine with a terminal alkyne substituent.

Alkene substituents could be introduced in the phthalocyanine core using a Heck reaction (Scheme 23). Alkene, alkyl, aryl, carboxyl, steroid and the other biologically related functional groups could be introduced by this reaction. ${ }^{218,220}$ Similarly, palladium-catalyzed Stille reaction between monoiodo-substituted $\mathrm{A}_{3} \mathrm{~B}$ phthalocyanines $\mathbf{6 2}$ and tributylstannylethylene leads to formation of the vinyl-containing phthalocyanine 74 (Scheme 26). ${ }^{221}$ In another synthetic strategy, carboxaldehyde-containing asymmetric phthalocyanine could be used for preparation of alkene-substituted phthalocyanines. The aldehydic $\mathrm{A}_{3} \mathrm{~B}$ phthalocyanines can be prepared in two steps. First, aldehyde-protected phthalocyanine should be prepared by statistical condensation with aldehyde-protected phthalonitrile because of the low stability of aldehyde group under 

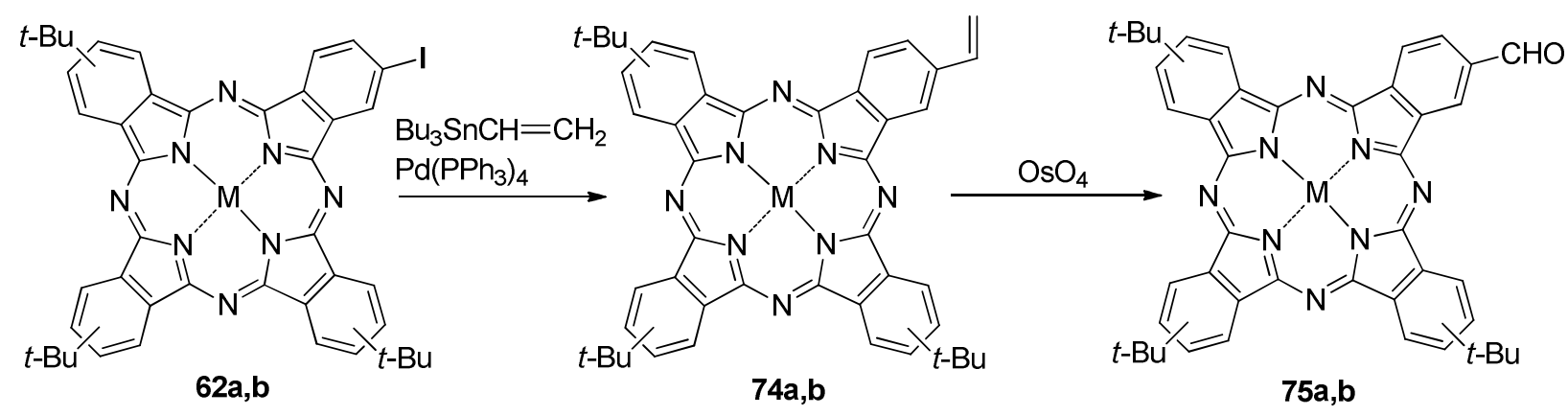

62a, 74a, 75a $\mathrm{M}=2 \mathrm{H}$,

62b, 74b, 75b M = Zn

Scheme 26. Synthetic strategies for preparation of the asymmetric vinyl-substituted phthalocyanines.

phthalocyanine condensation conditions. The protected $\mathrm{A}_{3} \mathrm{~B}$ phthalocyanine can then be deprotected to generate the peripheral aldehyde substituent. ${ }^{221}$ Another synthetic pathway to prepare aldehyde-containing phthalocyanine $\mathbf{7 5}$ is by oxidative cleavage of vinylphthalocyanine (Scheme 26). ${ }^{221}$ Prepared by any of the above-mentioned methods, an aldehyde-containing phthalocyanine can then form a desired conjugated alkene-bridged binuclear phthalocyanine in a Wittig reaction. ${ }^{222}$ The Heck reaction can also be used to prepare binuclear alkenyl-bridged $\mathrm{A}_{3} \mathrm{~B}$ phthalocyanines. One such example, phthalocyanine 72, formed by coupling between a vinylcontaining phthalocyanine and dihaloanthraquinone, is shown in Figure $4 .^{230}$

Direct phthalocyanine to $s p^{3}$ carbon bond formation could easily be achieved by the Suzuki coupling reaction. This synthetic approach can be used for preparation of mono- (Scheme 23) as well as di- and tri-nuclear (Figure 5) asymmetric phthalocyanines $\mathbf{7 6 - 7 8} .^{218,220,223,237,239}$ 


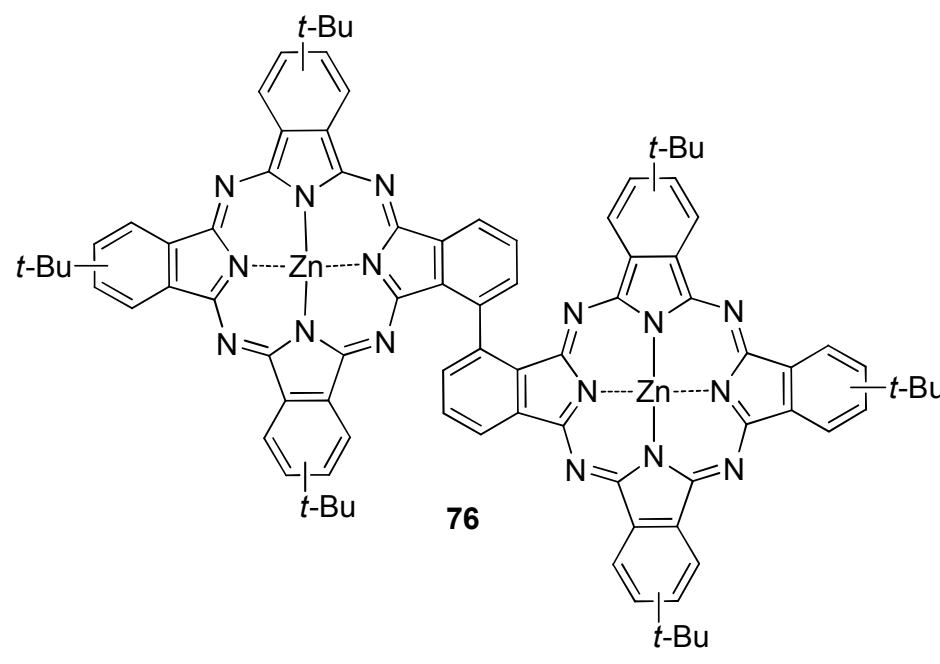

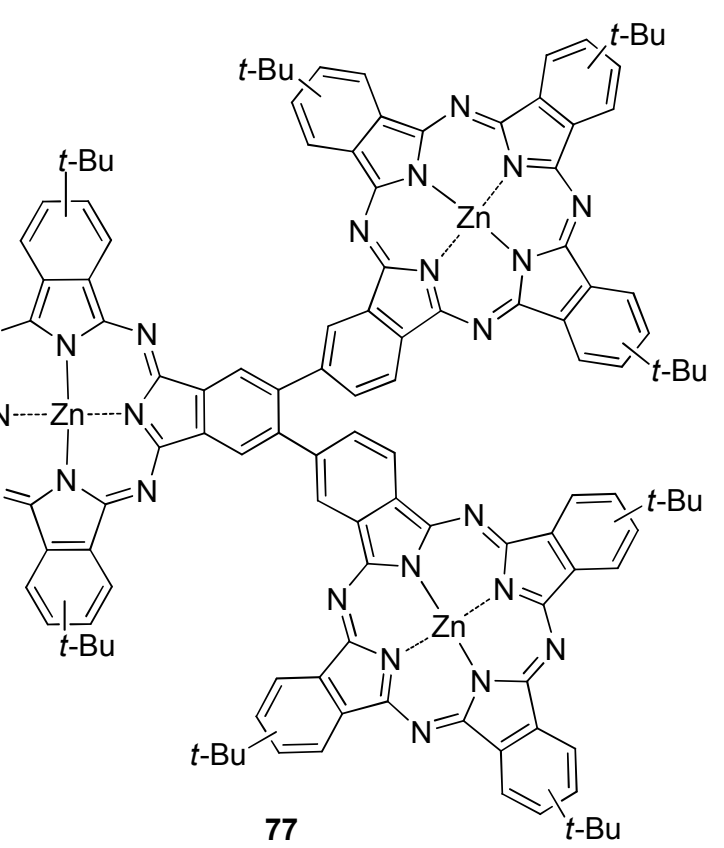

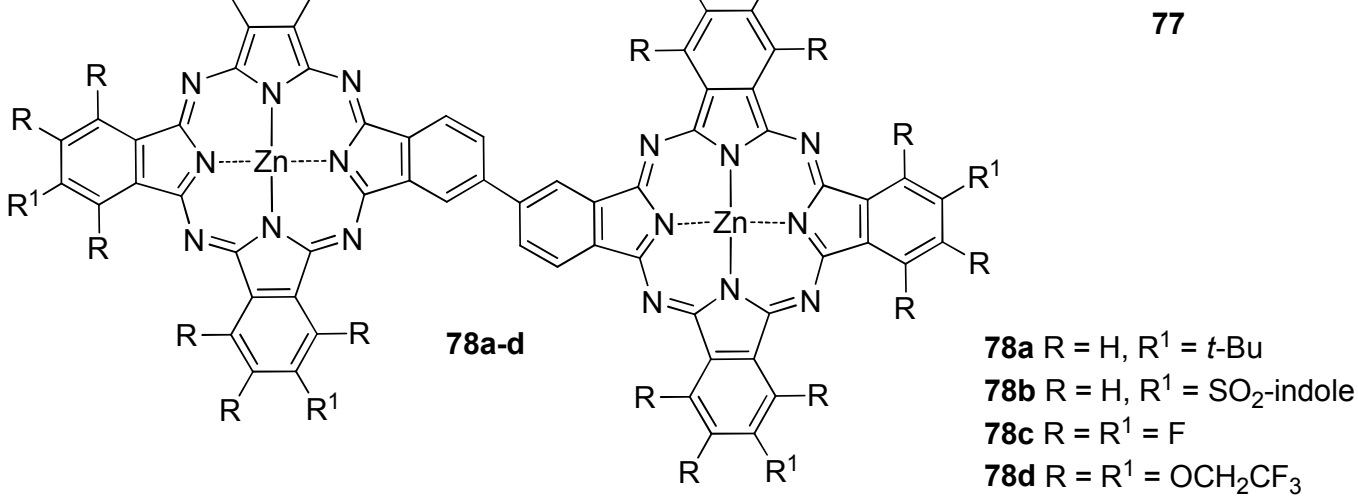

Figure 5. Representative examples of dimeric and trimeric phthalocyanines prepared using coupling reactions with formation of a direct carbon-carbon bond.

\subsection{Oxidative transformation strategy}

Peripheral oxidation transformation is a very popular approach for preparation of asymmetric functionalized porphyrins, ${ }^{244-255}$ but so far has only limited application in phthalocyanine chemistry. Thus, octa(dimethylamino)-substituted tetraazaporphyrins 79 can be oxidized by manganese(IV) oxide to form two different seco-porphyrazines 80 and $\mathbf{8 1}$ (Scheme 27A). ${ }^{256-258}$ 
Similarly, trifluoroacetic acid-catalyzed cleavage of different octasubstituted porphyrazines 82 results in aryl- or amino-substituted seco-porphyrazines $\mathbf{8 3}$ (Scheme 27B). ${ }^{259-261}$

Another interesting oxidation reaction is shown in Scheme 28. In this case, oxygen can form an adduct with anthracyanines $\mathbf{8 4}$ to form a variety of symmetric and asymmetric compounds, e.g. 85, which could be reversibly transformed into the starting material. ${ }^{262}$

A)

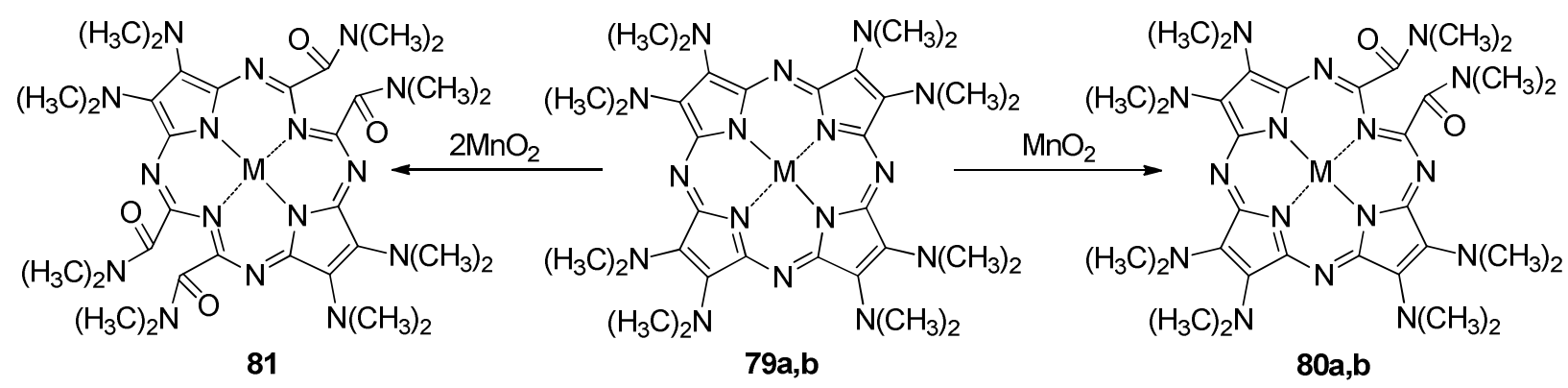

$79 \mathrm{a}, 80 \mathrm{a} M=2 \mathrm{H}$

$79 b, 80 b, 81 M=Z n$

B)

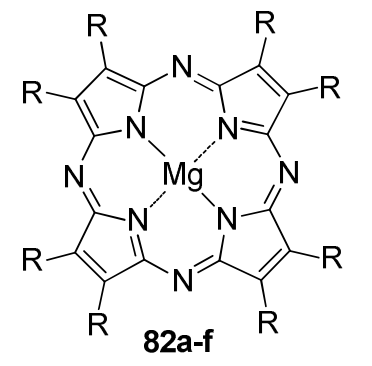

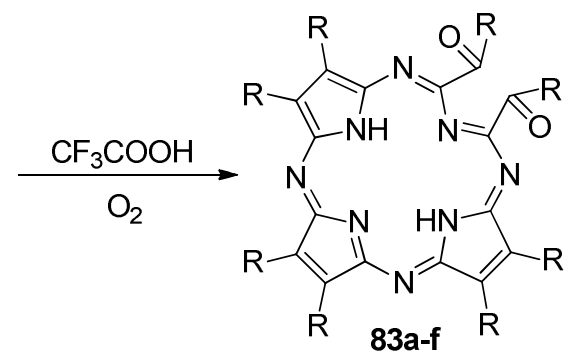

82a, 83a $\mathrm{R}=\mathrm{N}\left(\mathrm{CH}_{3}\right)_{2}$

$82 b, 83 b R=$<smiles>c1ccccc1</smiles><smiles>Cc1ccccc1</smiles><smiles></smiles><smiles>CC(C)(C)OCc1cccc2ccccc12</smiles>

82c, 83c R<smiles>Cc1ccccc1C</smiles><smiles>CC(C)(C)O[Mg]</smiles>

Scheme 27. Formation of asymmetric seco-porphyrazines using oxidation reactions. 


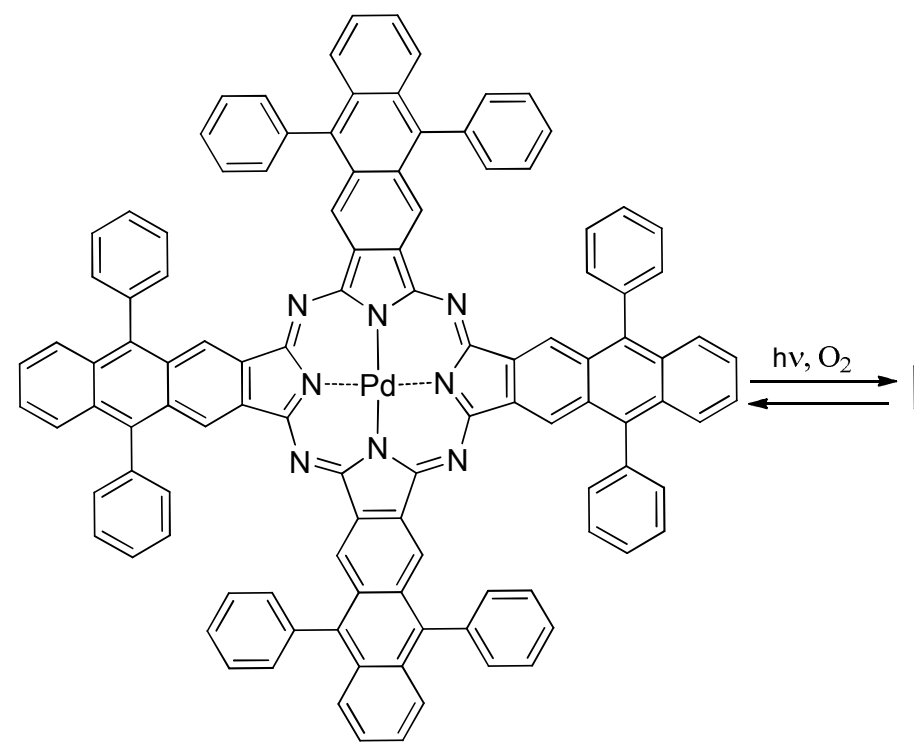

84

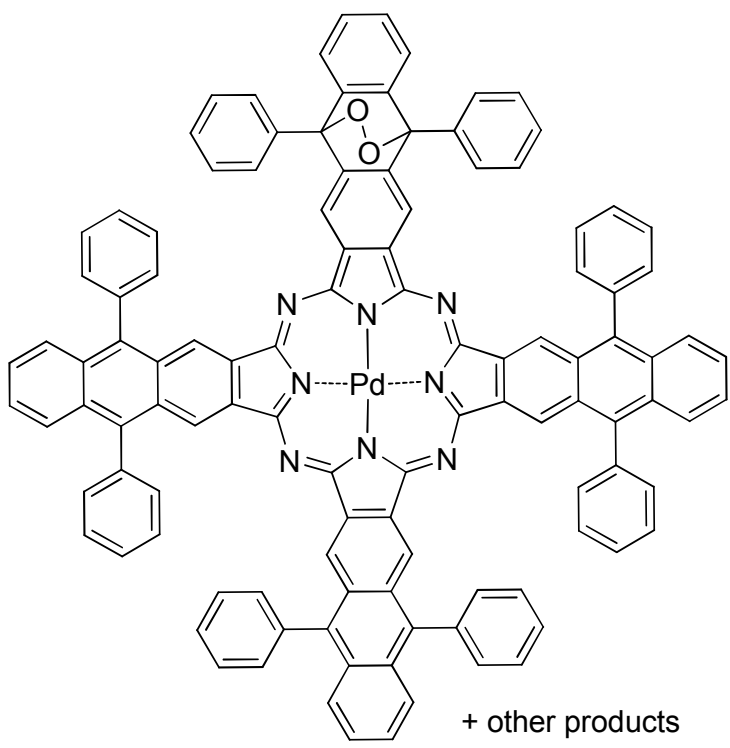

$85 a$

Scheme 28. Reversible partial oxidation of an anthracyanine using molecular oxygen.

\subsection{Simple aromatic electrophilic or nucleophilic reactions}

In general, aromatic substitution reactions could be used for preparation of asymmetric phthalocyanines. For instance, it was suggested that the nitration of the unsubstituted symmetric phthalocyanine 86 with $\left[\mathrm{NO}_{2}\right]^{+}$electrophile results in formation of the mononitro $\mathrm{A}_{3} \mathrm{~B}$ type derivative 88 (Scheme 29). ${ }^{263}$ Similarly, depending on the reaction conditions (solvent and the temperature) and reactants used (sulfuric acid, oleum, or chlorosulfonic acid), unsubstituted phthalocyanines 86 can be modified with one up to four sulfogroups located at so-called "peripheral" $(\beta)$ or so-called "non-peripheral" $(\alpha)$ positions. It has been shown that the asymmetric di- and trisulfo-substituted phthalocyanines $\mathbf{8 9}$ prepared in this way are the most active in photodynamic cancer therapy (PDT) (Scheme 29). ${ }^{23}$

Chen and co-workers have shown that direct lithiation of the unsubstituted phthalocyanines takes place predominantly at non-peripheral $(\alpha)$ positions of the phthalocyanine core. ${ }^{264}$ The lithium salts from this reaction can be quenched with a variety of reactants. For instance, when unsubstituted metal-free phthalocyanine 86 was treated with lithium 2,2,6,6-tetramethylpiperidine and the resulting salt was quenched with chlorotrimethylsilane, a mixture of trimethylsilyl-substituted phthalocyanines, $\left(\mathrm{Me}_{3} \mathrm{Si}_{\mathrm{n}} \mathrm{PcH}_{2}(\mathrm{n}=2-4) 87\right.$ was formed. This mixture was further separated using column chromatography to yield asymmetric $(\mathrm{n}=2-3)$ phthalocyanines (Scheme 29). ${ }^{264}$ 


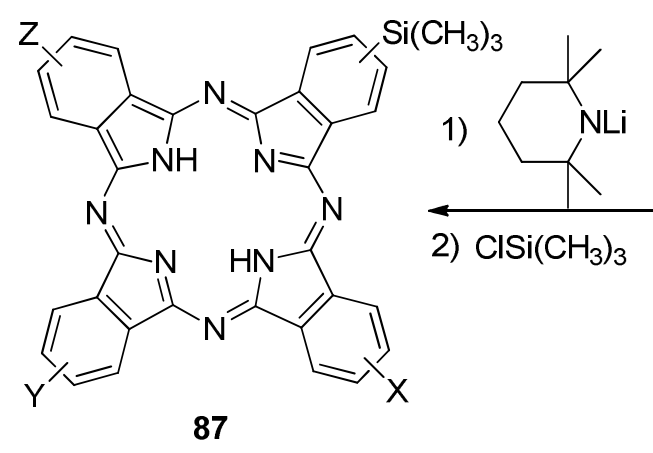

$87 \mathrm{X}, \mathrm{Y}, \mathrm{Z}=\mathrm{H}$ or $\mathrm{Si}\left(\mathrm{CH}_{3}\right)_{3}$

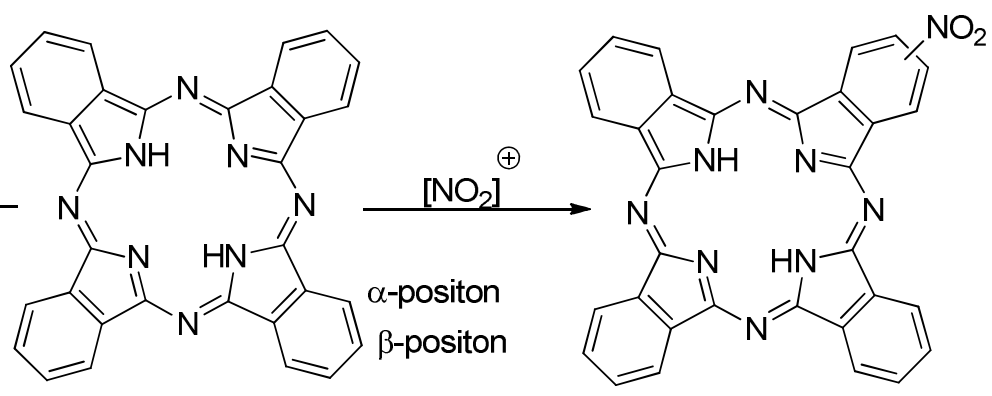

86

$\mathrm{ClSO}_{3} \mathrm{H}$

or

$\mathrm{SO}_{3} / \mathrm{H}_{2} \mathrm{SO}_{4}$

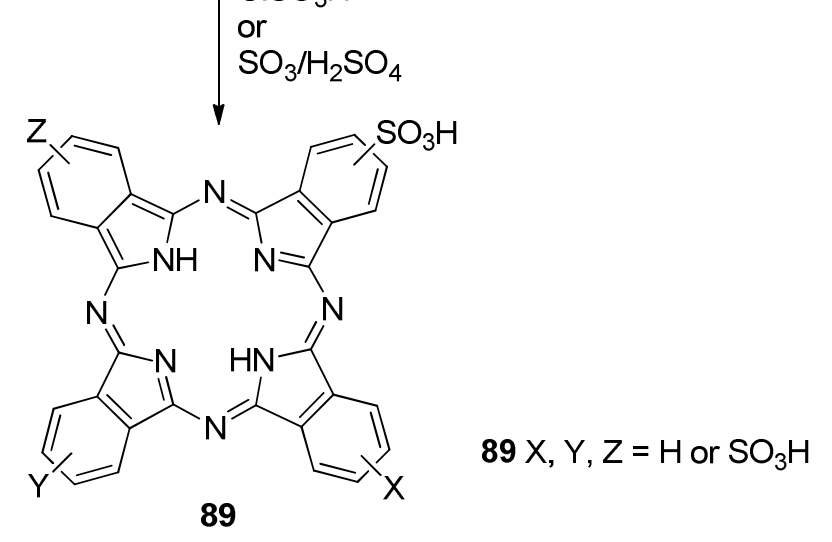

$89 \mathrm{X}, \mathrm{Y}, \mathrm{Z}=\mathrm{H}$ or $\mathrm{SO}_{3} \mathrm{H}$

Scheme 29. Formation of asymmetric phthalocyanine derivatives using simple aromatic nucleophilic or electrophilic substitution reactions.

Another synthetic strategy, using nucleophilic aromatic substitution in symmetric phthalocyanines to form asymmetric derivatives, was developed by Leznoff and co-workers. ${ }^{265-267}$ This research group showed that the C-F bonds in zinc hexadecafluorophthalocyanine $\mathbf{9 0}$ could be replaced by a variety of carbon-, oxygen-, sulfur-, and nitrogen-centered nucleophillic reagents to form mixtures of asymmetric phthalocyanines 91 with various degrees of substitution. The reaction product distribution was studied by mass spectrometry. It was found that such aromatic nucleophilic substitution reaction results in formation of several products rather than individual compounds, although in several cases authors have seen narrowly distributed mixtures of polysubstituted products. The average number of oxygen-, nitrogen-, sulfur-, and carboncentered nucleophiles present in the reaction product correlates well with their relative nucleophilicity and increases in the order: $\mathrm{HNRR}^{\prime}<\mathrm{RO}^{-}<\mathrm{CN}^{-}<\mathrm{RS}^{-}$(Scheme 30). ${ }^{265,266}$ The reactivity of $\mathbf{9 0}$ was further investigated in aromatic nucleophilic substitution reactions with primary and secondary amines as well as tertiary butyl esters of aminoacids as nucleophiles, using various reaction conditions. ${ }^{265-267}$ It was found that asymmetric mono- and di-substituted fluorophthalocyanines are formed under mild reaction conditions, while higher degrees of substitution can be achieved with the amines as the reaction solvents. If diamines were used as the nucleophiles, the reaction products are mixtures of cyclic substituted phthalocyanines, 
binuclear and trinuclear (amine bridged) compounds, or mixtures of both of these types depending on the structures of the diamines used. ${ }^{265-267}$

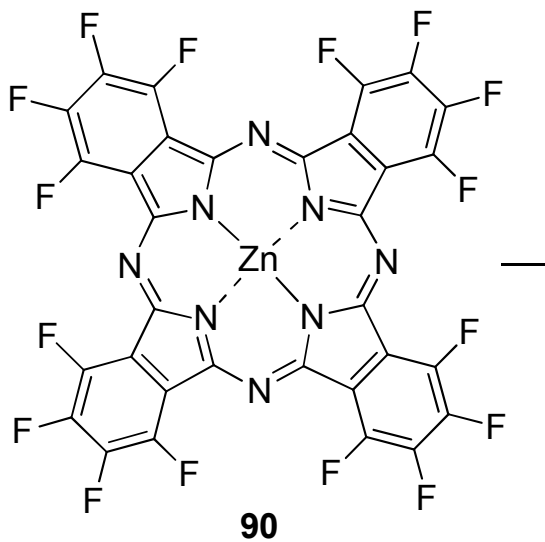

Nucleophile $\left(\mathrm{R}^{-}\right)$

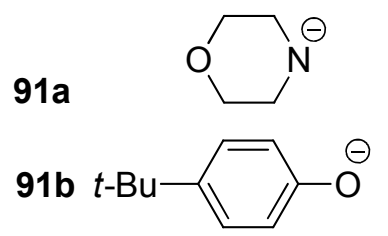

91c $\left(\mathrm{CH}_{3}\right)_{3} \mathrm{CCH}_{2} \stackrel{\ominus}{\mathrm{O}}$

91d $\quad \mathrm{CN} \odot$

91e $\quad \mathrm{CH}_{3}\left(\mathrm{CH}_{2}\right)_{7} \stackrel{\ominus}{\mathrm{S}}$
$\mathrm{Nu}: \mathrm{diglyme}$

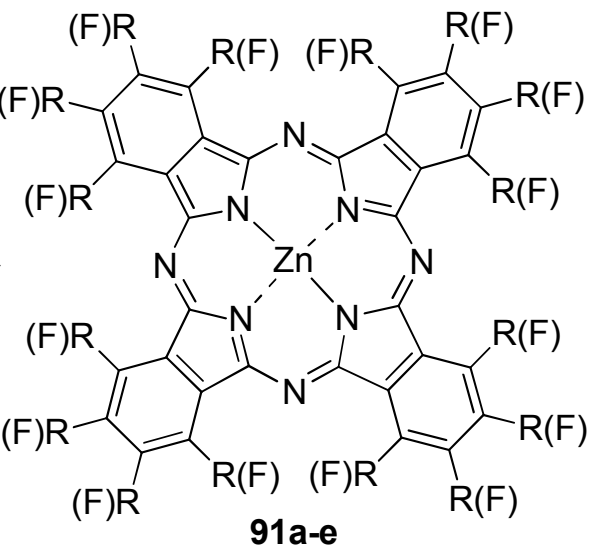

Average number of replaced fluorine atoms

8

12

12

14

16

Scheme 30. Formation of asymmetric phthalocyanines using partial substitution of the peripheral $\mathrm{C}-\mathrm{F}$ bonds in hexadecafluorophthalocyanine.

\subsection{Peripheral substituent coordination approach}

Peripheral substituents in symmetric and asymmetric phthalocyanines can be used for further coordination of transition-metal ions or formation of supramolecular assemblies. ${ }^{268-275}$ For instance, asymmetric $\mathrm{A}_{3} \mathrm{~B}$ type phthalocyanine analogues can easily form mono- or dinuclear phthalocyanine analogues 92-95 when reacted with the main-group or transition-metal ions (Figure 6). Similarly, Ercolani and co-workers have shown that six out of eight available pyridine-type nitrogen atoms in symmetric phthalocyanine could be methylated using standard methylation agents. ${ }^{274}$ The remaining two pyridine substituents could be coordinated to transition-metal ions to form asymmetric phthalocyanines 96. Such platinum-containing compounds are potentially useful for combinational (PDT and chemical cytotoxicity) therapy of cancer (Figure 6). In addition, they easily form DNA intercalates which leads to DNA damage. 


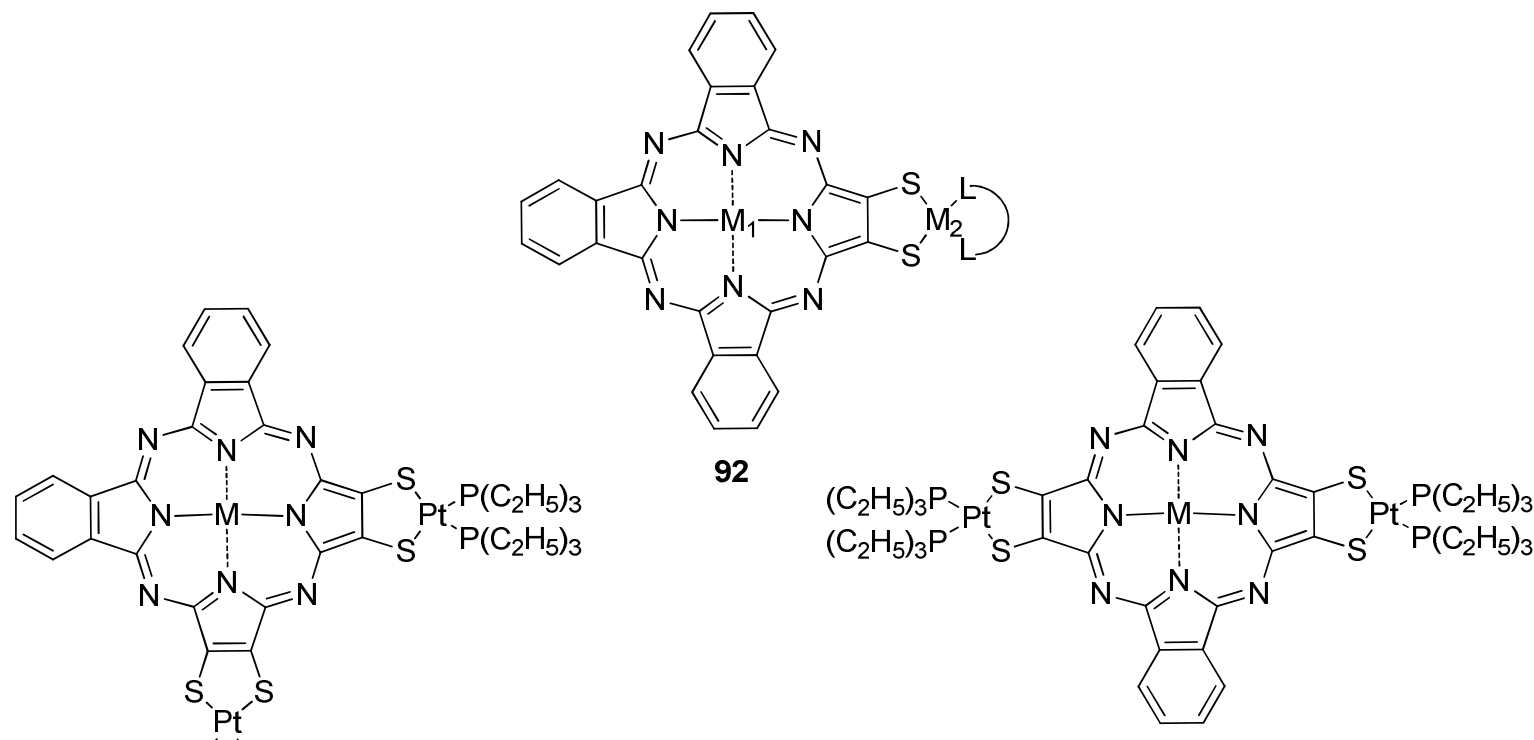

$\left(\mathrm{C}_{2} \mathrm{H}_{5}\right)_{3} \mathrm{P}^{\prime} \mathrm{P}\left(\mathrm{C}_{2} \mathrm{H}_{5}\right)_{3}$
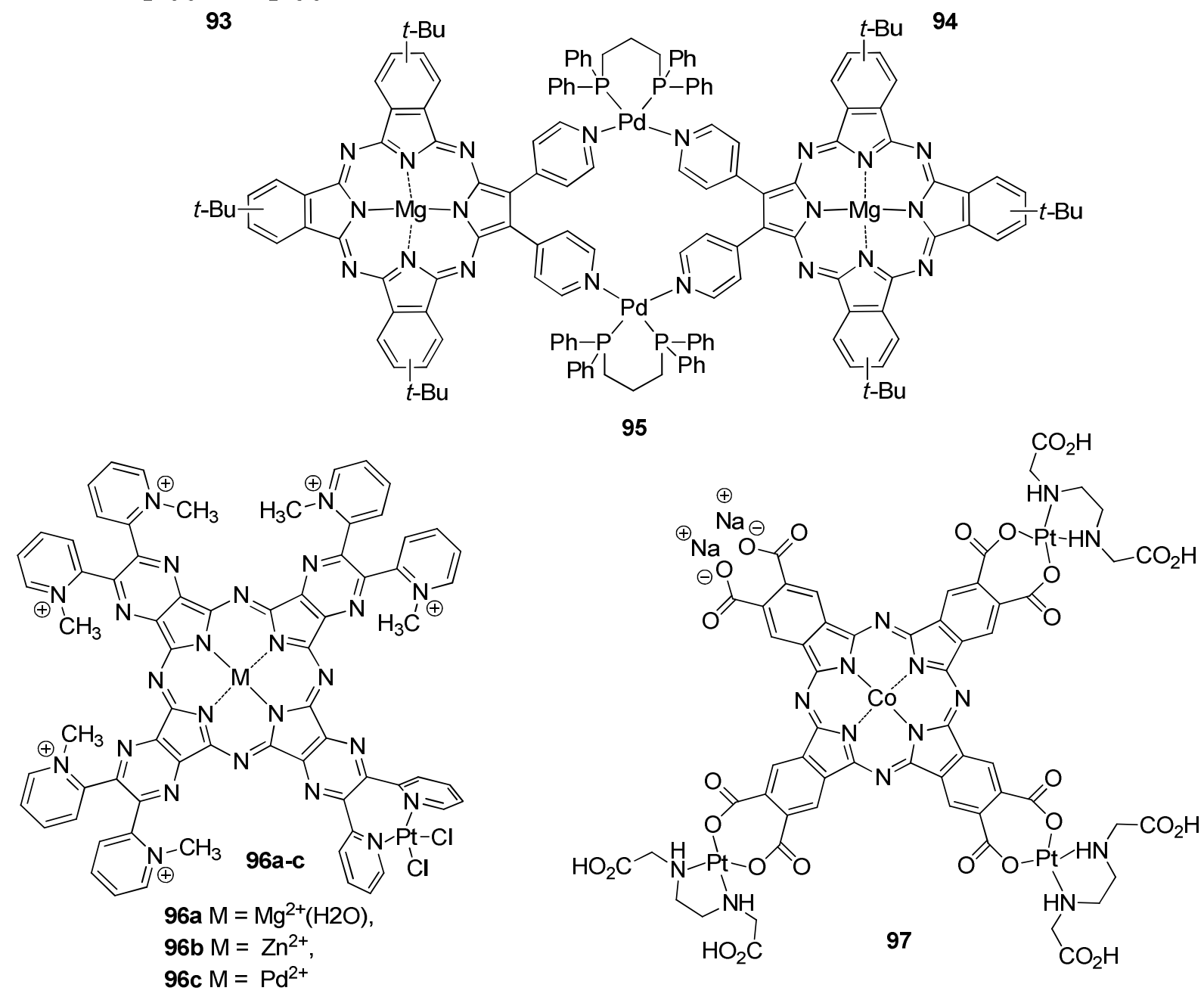

Figure 6. Representative examples of asymmetric phthalocyanines and their analogues formed using the coordination approach. 
Kalya and co-workers have shown that analogues with partial platinum ions coordination to octacarboxyphthalocyanines lead to formation of asymmetric platinum-containing derivatives 97 potentially useful in combinational cancer therapy (Figure 6). ${ }^{276}$

\section{Miscellaneous Strategies}

An interesting set of seco-tribenzoporphyrazines was reported in 2012 and later in 2013 (Scheme 31). ${ }^{277,278}$ In the initial report, it was found that statistical condensation between 1,3diiminoisoindolines and 2,5-diamino-3,4-dicyanothiophene in the presence of the nickel salt results in the formation of nickel seco-tribenzoporphyrazines $\mathbf{9 8 a}, \mathbf{b} .^{277}$ Later on, it was shown that the same nickel and palladium seco-tribenzoporphyrazines $\mathbf{9 8 c , d}$ could be formed even when 1,3-diiminoisoindolines were reacted with the transition-metal salts. ${ }^{278}$ The reaction mechanism and the scope of such seco-tribenzoporphyrazine core formation is still unclear.

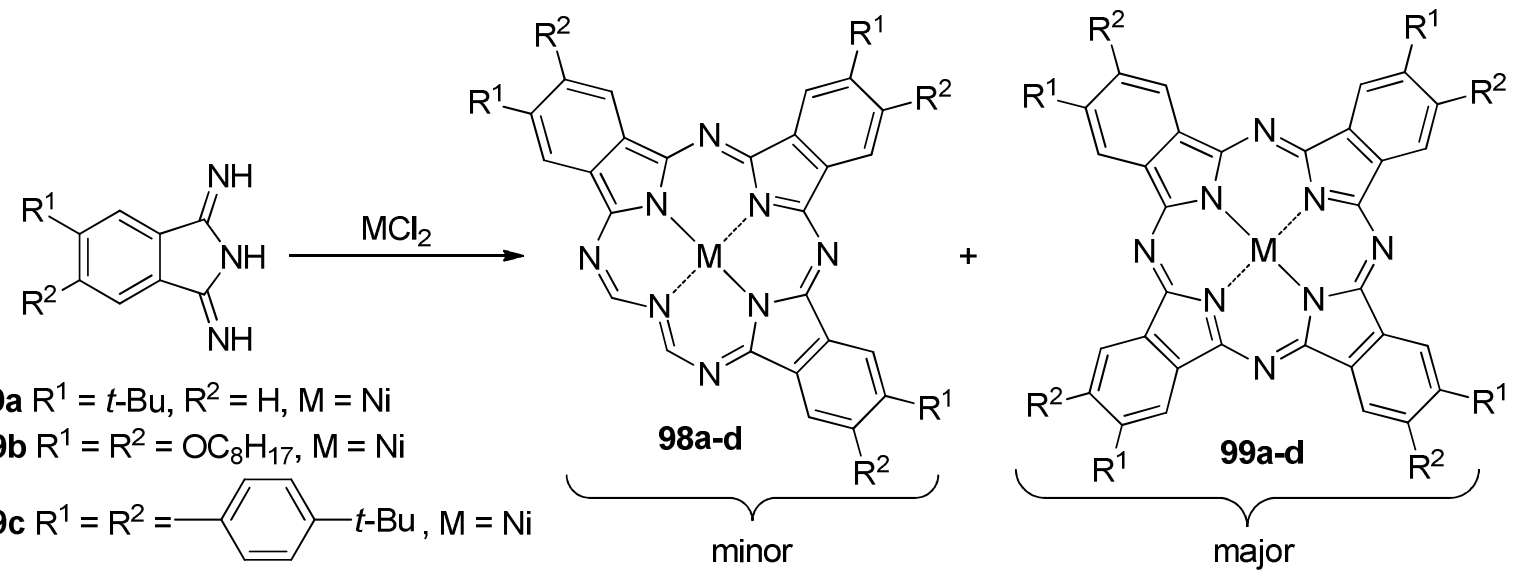

98a, 99a $\mathrm{R}^{1}=t-\mathrm{Bu}, \mathrm{R}^{2}=\mathrm{H}, \mathrm{M}=\mathrm{Ni}$

98b, 99b $\mathrm{R}^{1}=\mathrm{R}^{2}=\mathrm{OC}_{8} \mathrm{H}_{17}, \mathrm{M}=\mathrm{Ni}$

98c, 99c $\mathrm{R}^{1}=\mathrm{R}^{2}=$

minor

major

98d, 99d $\mathrm{R}^{1}=\mathrm{R}^{2}=$

Scheme 31. Formation of seco-tribenzoporphyrazines using direct condensation of 1,3-diiminoisoindoline.

Leznoff, Kobayashi, and co-workers shown that the long-time assumed formation of the square-planar $\mathrm{Au}(\mathrm{II})$ phthalocyanine $\mathbf{1 0 1}$ does not correctly reflect the reaction products. ${ }^{279}$ Indeed, these authors observed formation of the expected $\mathrm{PcAuCl}$ complex along with an unusual macrocycle 100, which can be converted into $\mathrm{PcAuCl}$ under specific conditions (Scheme 32). ${ }^{279}$

An interesting conjugated polymer was prepared from the asymmetric thiophene-containing ABAB phthalocyanine. Polymerization was conducted on the thiophene-substituted phthalocyanine at electrochemical oxidation conditions. ${ }^{280}$ Finally, two asymmetrically substituted phthalocyanines (102 and 103) of $\mathrm{A}_{3} \mathrm{~B}$ type were prepared by statistical condensation 
and used to form double-decker terbium complexes. ${ }^{281-283}$ The synthetic routes are tedious, but they provide an access to the derivatives represented in Figure 7.

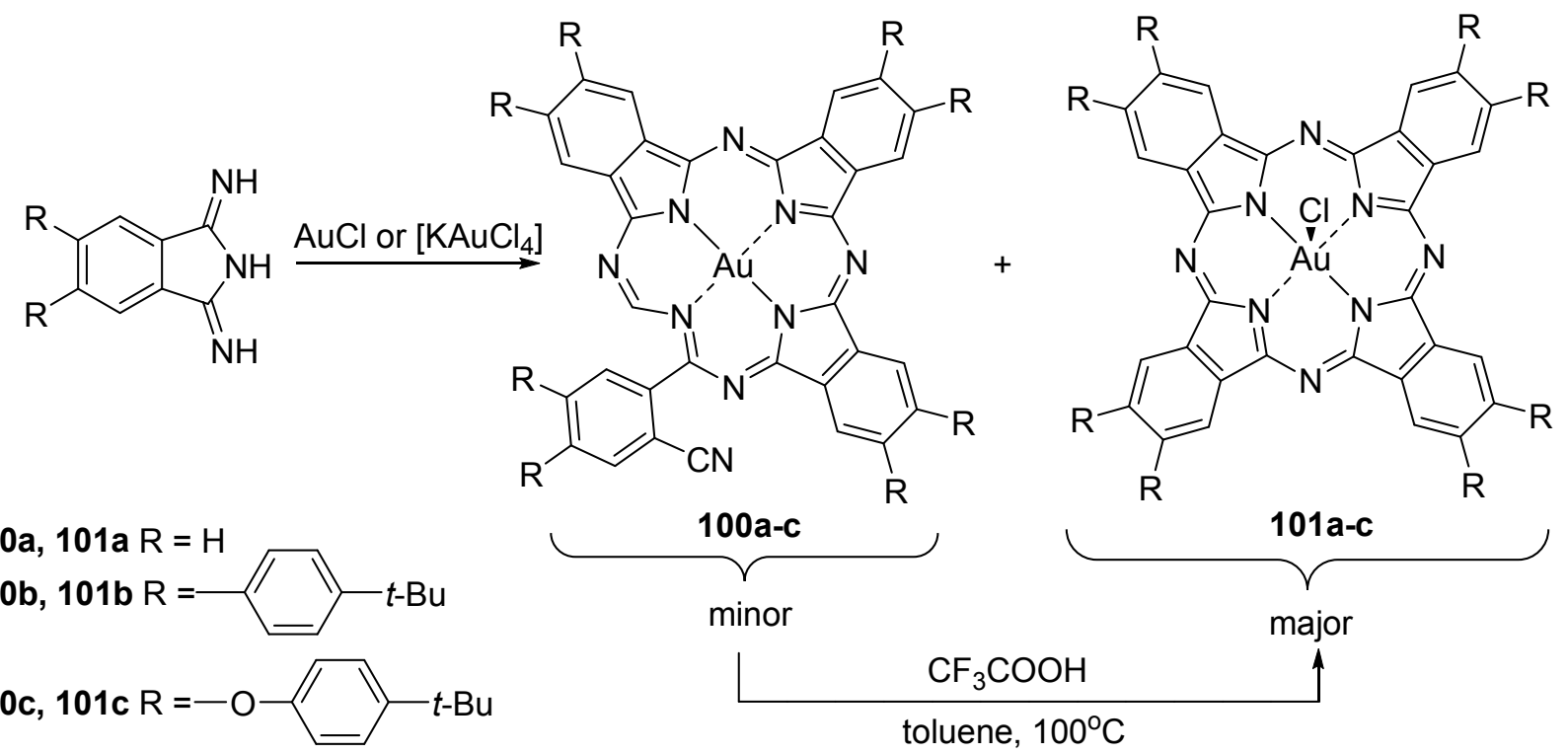

Scheme 32. Formation of seco-tribenzoporphyrazines by direct condensation of 1,3diiminoisoindoline in the presence of $\mathrm{Au}^{+}$or $\mathrm{Au}^{3+}$ salts.

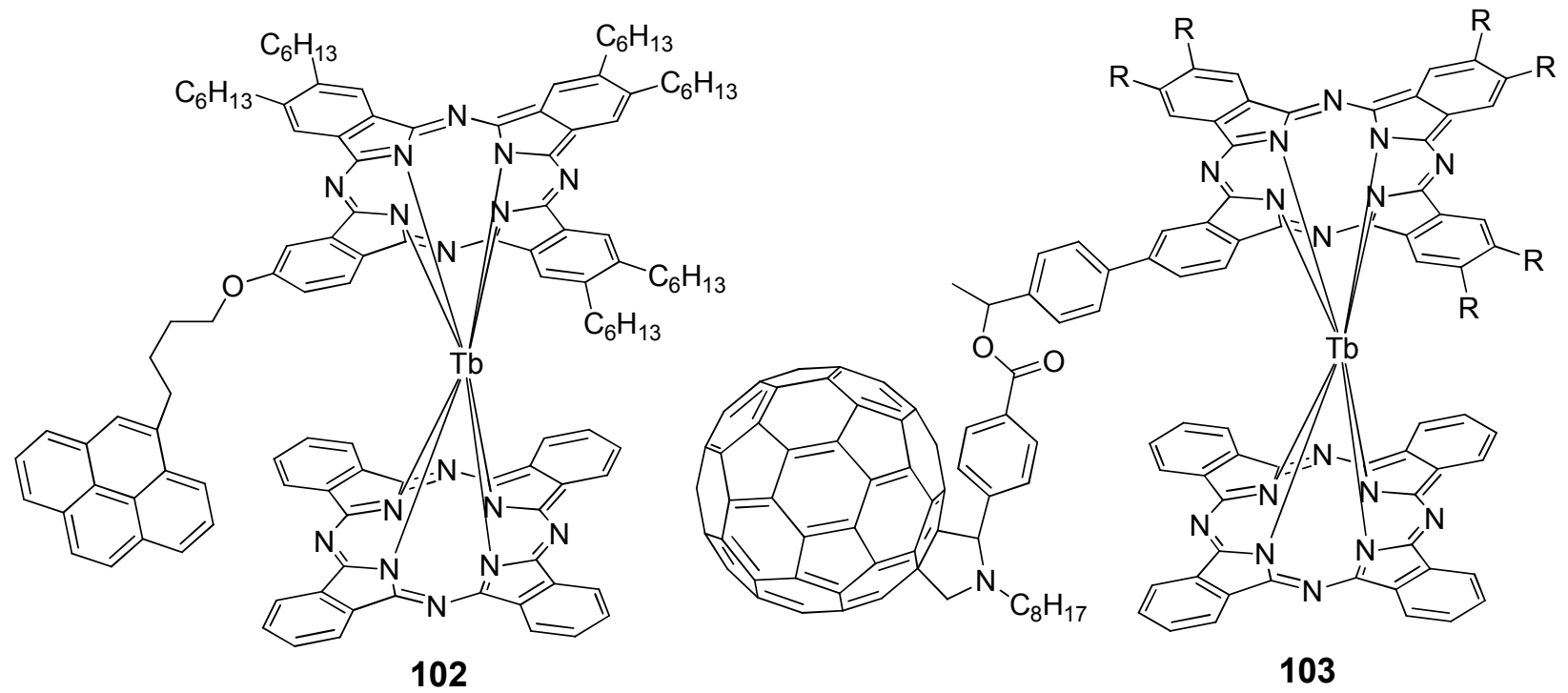

Figure 7. Examples of double-decker complexes which include asymmetric $\mathrm{A}_{3} \mathrm{~B}$ type phthalocyanine fragments. 


\section{Acknowledgements}

Generous support from the NSF CHE-1110455, Minnesota Supercomputing Institute, and U of M Grant-in-Aid to VN is greatly appreciated.

\section{References}

1. Linstead, R. P. J. Chem. Soc. 1934, 1016.

2. Byrne, G. T.; Linstead, R. P.; Lowe, A. R. J. Chem. Soc. 1934, 1017. http://dx.doi.org/10.1039/jr9340001017

3. Linstead, R. P.; Lowe, A. R. J. Chem. Soc. 1934, 1022. http://dx.doi.org/10.1039/jr9340001022

4. Dent, C. E.; Linstead, R. P.; Lowe, A. R. J. Chem. Soc. 1934, 1033. http://dx.doi.org/10.1039/jr9340001033

5. Robertson, J. M. J. Chem. Soc. 1934, 615.

6. Robertson, J. M.; Linstead, R. P.; Dent, C. E. Nature 1935, 135, 506. http://dx.doi.org/10.1038/135506b0

7. Robertson, J. M; Woodward, I. J. Chem. Soc. 1937, 219. http://dx.doi.org/10.1039/jr9370000219

8. Moser, F. H.; Thomas, A. L. In Phthalocyanine Compounds; Reinold Publ. Corp.: New York, 1963.

9. Moser, F. H.; Thomas A. L. In The Phthalocyanines; CRC Press: Boca Raton, 1983; Vol. 2.

10. Nemykin, V. N.; Lukyanets, E. A. Arkivoc 2010, (i), 136. http://dx.doi.org/10.3998/ark.5550190.0011.104

11. Lukyanets, E. A.; Nemykin, V. N. J. Porphyrins Phthalocyanines 2010, 14, 1. http://dx.doi.org/10.1142/S1088424610001799

12. Nemykin, V. N.; Lukyanets, E. A. in Handbook of porphyrin science; Kadish, K. M.; Smith, K. M.; Guilard, R. Eds.; World Scientific Publ.: Singapore, 2010; Vol. 3, p. 1.

13. Darwent, J. R.; Douglas, P.; Harriman, A.; Porter, G.; Richoux, M. C. Coord. Chem. Rev. 1982, 44, 83 . http://dx.doi.org/10.1016/S0010-8545(00)80518-4

14. Lever, A. B. P.; Hempstead, M. R.; Leznoff, C. C.; Liu, W.; Melnik, M.; Nevin, W. A.; Seymour, P. Pure Appl. Chem. 1986, 58, 1467. http://dx.doi.org/10.1351/pac198658111467

15. Zagal, J. H. Coord. Chem. Rev. 1992, 119, 89. http://dx.doi.org/10.1016/0010-8545(92)80031-L

16. Kaliya, O. L.; Lukyanets, E. A.; Vorozhtsov, G. N. J. Porphyrins Phthalocyanines 1999, 3, 592. 
http://dx.doi.org/10.1002/(SICI)1099-1409(199908/10)3:6/7<592::AID-JPP180>3.0.CO;2$\underline{\mathrm{G}}$

17. Sorokin, A. In Photosensitizers in medicine, environment and security; Nyokong, T.;

Ahsen, V. Eds.; Springer: Dordrecht, 2012; p. 433.

18. Sorokin, A. Chem. Rev. 2013, 113, 8152.

http://dx.doi.org/10.1021/cr4000072

PMid:23782107

19. Spikes, J. D. Photochem. Photobiol. 1986, 43, 691.

http://dx.doi.org/10.1111/j.1751-1097.1986.tb05648.x

PMid:3092251

20. Rosenthal, I. Photochem. Photobiol. 1991, 53, 859.

PMid:1886943

21. Bonnett, R. Chem. Soc. Rev. 1995, 24, 19.

http://dx.doi.org/10.1039/cs9952400019

22. Rosenthal, I. In Phthalocyanines: properties and applications; Leznoff, C. C,; Lever, A. B. P. Eds.; VCH Publ. Inc.: New York, 1996; Vol. 4, p. 481.

23. Lukyanets, E. A. J. Porphyrins Phthalocyanines 1999, 3, 424. http://dx.doi.org/10.1002/(SICI)1099-1409(199908/10)3:6/7<424::AID-JPP151>3.0.CO;2$\underline{\mathrm{K}}$

24. Bonnett, R. In Chemical aspects of photodynamic therapy; Gordon and Breach, Amsterdam, 2000; p 199.

25. Wainwright, M. In Photosensitisers in Biomedicine; John Wiley \& Sons: Oxford, 2009; p. 147.

http://dx.doi.org/10.1002/9780470744956.ch7

26. Ali, H.; van Lier J. E. In Handbook of Porphyrin Science; Kadish, K. M.; Smith, K. M.; Guilard, R. Eds.; World Scientific Publ.: Singapore, 2010; Vol. 4, p. 1.

27. Costa, S. M. B.; Andrade, S. M.; Togashi, D. M.; Paulo, P. M. R.; Laia, C. A. T.; Isabel Viseu, M.; Goncalves da Silva, A. M. J. Porphyrins Phthalocyanines 2009, 13, 509. http://dx.doi.org/10.1142/S1088424609000589

28. Sekkat, N.; van den Bergh, H.; Nyokong, T.; Lange, N. Molecules 2012, 17, 98. http://dx.doi.org/10.3390/molecules17010098

PMid:22198535

29. Jori, G. J. Environ. Pathol. Tox. 2006, 25, 505. http://dx.doi.org/10.1615/JEnvironPatholToxicolOncol.v25.i1-2.320

30. Maisch, T. Anti-Infect. Agents Med. Chem. 2007, 6, 145. http://dx.doi.org/10.2174/187152107780361634

31. Donnelly, R. F.; McCarron, P. A.; Tunney, M. M. Microbiol. Res. 2008, 163, 1. http://dx.doi.org/10.1016/j.micres.2007.08.001

PMid:18037279

32. Maisch, T. Mini-Rev. Med. Chem. 2009, 9, 974. 
http://dx.doi.org/10.2174/138955709788681582

PMid:19601890

33. Gregory, P. J. Porphyrins Phthalocyanines 2000, 4, 432. http://dx.doi.org/10.1002/(SICI)1099-1409(200006/07)4:4<432::AID-JPP254>3.0.CO;2-N

34. Zhou, R.; Josse, F.; Göpel, W.; Öztürk, Z. Z.; Bekaroğlu, O. Appl. Organometal. Chem. 1996, 10, 557.

http://dx.doi.org/10.1002/(SICI)1099-0739(199610)10:8<557::AID-AOC521>3.0.CO;2-3

35. Valli, L. Adv. Colloid Interface Sci. 2005, 116, 13.

http://dx.doi.org/10.1016/j.cis.2005.04.008

PMid:16112639

36. Bouvet, M. Anal. Bioanal. Chem. 2006, 384, 366. http://dx.doi.org/10.1007/s00216-005-3257-6

PMid:15933850

37. Öztürk, Z. Z.; Kılınç, N.; Atilla, D.; Gürek, A. G.; Ahsen, V. J. Porphyrins

Phthalocyanines 2009, 13, 1179.

http://dx.doi.org/10.1142/S1088424609001522

38. Li, L.; Tang, Q.; Li, H.; Hu, W.; Yang, X.; Shuai, Z.; Liu, Y.; Zhu, D. Pure Appl. Chem. 2008, 80, 2231. http://dx.doi.org/10.1351/pac200880112231

39. de la Torre, G. Nicolau, M.; Torres T. In Supramolecular Photosensitive and Electroactive materials; Nalwa, H. S. Ed; Academic Press: San Diego, 2001; p 1. http://dx.doi.org/10.1016/B978-012513904-5/50003-X

40. Hanabusa, K.; Shirai, H. in Phthalocyanines: Properties and Applications; Leznoff, C. C,; Lever, A. B. P. Eds.; VCH Publ. Inc.: New York, 1993; Vol. 2, p. 197.

41. Simon, J.; Bassoul, P. In Phthalocyanines: Properties and Applications; Leznoff, C. C,; Lever, A. B. P. Eds.; VCH Publ. Inc.: New York, 1993; Vol. 2, p. 223.

42. Cammidge, A. N.; Bushby, R. J. In Handbook of Liquid Crystals; Demus, D. Ed.; WileyVCH Verlag GmbH.: Weinheim, 1998; Vol. 2B, p. 693.

43. Ohta, K.; Hatsusaka, K.; Sugibayashi, M.; Ariyoshi, M.; Ban, K.; Maeda, F.; Naito, R.; Nishizawa, K.; van de Craats, A. M.; Warman, J. M. Mol. Cryst. Liquid Cryst. 2003, 397, 325.

http://dx.doi.org/10.1080/714965592

44. Wöhrle, D.; Schnurpfeil, G.; Makarov, S. G.; Kazarin, A.; Suvorova, O. N. Makroheterocycles 2012, 5, 191. http://dx.doi.org/10.6060/mhc2012.120990w

45. Wöhrle, D.; Kreienhoop, L.; Schlettwein, D. In Phthalocyanines: Properties and Applications; Leznoff, C. C,; Lever, A. B. P. Eds.; VCH Publ. Inc.: New York, 1996; Vol. 4, p. 219.

46. Claessens, C. G.; Hahn, U.; Torres, T. Chem. Record 2008, 8, 75. 
http://dx.doi.org/10.1002/tcr.20139

PMid:18366105

47. Martinez-Diaz, V. M.; Diaz Diaz, D. J. Porphyrins Phthalocyanines 2009, 13, 397. http://dx.doi.org/10.1142/S1088424609000735

48. Walter, M. G.; Rudine, A. B.; Wamser, C. C. J. Porphyrins Phthalocyanines 2010, 14, 759. http://dx.doi.org/10.1142/S1088424610002689

49. Martinez-Diaz, V. M.; Torres, T. In Handbook of Porphyrin Science; Kadish, K. M.; Smith, K. M.; Guilard, R. Eds.; World Scientific Publ.: Singapore, 2010; Vol. 10, p. 141.

50. Imahori, H.; Kurotobi, K.; Walter, M. G.; Rudine, A. B.; Wamser, C. C. In Handbook of Porphyrin Science; Kadish, K. M.; Smith, K. M.; Guilard, R. Eds.; World Scientific Publ.: Singapore, 2012; Vol. 18, p. 57.

51. Schlettwein, D.; Nyokong, T. In Handbook of Porphyrin Science; Kadish, K. M.; Smith, K. M.; Guilard, R. Eds.; World Scientific Publ.: Singapore, 2012; Vol. 24, p. 389.

52. Elemans, J. A. A. W.; van Hameren, R.; Nolte, R. J. M.; Rowan, A. E. Adv. Materials 2006, $18,1251$.

http://dx.doi.org/10.1002/adma.200502498

53. de la Torre, G.; Claessens, C. G.; Torres, T. Chem. Commun. 2007, 2000.

54. Zhang, L.; Wang, L. J. Material. Sci. 2008, 43, 5692.

http://dx.doi.org/10.1007/s10853-008-2826-4

55. Bottari, G.; de la Torre, G.; Guldi, D. M.; Torres, T. Chem. Rev. 2010, 110, 6768. http://dx.doi.org/10.1021/cr900254z

PMid:20364812

56. D'Souza, F.; Ito, O. Chem. Soc. Rev. 2012, 41, 86.

http://dx.doi.org/10.1039/c1cs15201g

PMid:21975532

57. Schultz, H.; Lehmann, H.; Rein, M.; Hanack, M. Struct. Bond. 1991, 74, 41. http://dx.doi.org/10.1007/3-540-52899-7_2

58. Ayhan, M.M.; Singh, A.; Hirel, C.; Gürek, A.G.; Ahsen, V.; Jeanneau, E.; Ledoux-Rak, I.; Zyss, J.; Andraud, C.; Bretonnière, Y. J. Am. Chem Soc. 2012 134, 3655. http://dx.doi.org/10.1021/ja211064a

PMid:22308960

59. Nalwa, H. S.; Shirk, J. A. In Phthalocyanines: Properties and Applications; Leznoff, C. C,; Lever, A. B. P. Eds.; VCH Publ. Inc.: New York, 1996; Vol. 4, p 79.

60. Hanack, M.; Schneider, T.; Barthel, M.; Shirk, J. S.; Flom, S. R.; Pong, R. G. S. Coord. Chem. Rev. 2001, 219-221, 235. http://dx.doi.org/10.1016/S0010-8545(01)00327-7

61. Hanack, M.; Dini, D.; Barthel, M.; Vagin, S. Chem. Record 2002, 2, 129. http://dx.doi.org/10.1002/tcr.10024

PMid:12112866 
62. Flom, S. R. In Porphyrin Handbook; Kadish, K. M.; Smith, K. M.; Guilard, R. Eds.; Academic Press: San Diego, 2003; Vol. 19, p. 179. http://dx.doi.org/10.1016/B978-0-08-092393-2.50011-1

63. de la Torre, G.; Vazquez, P.; Agullo-Lopez, F.; Torres, T. Chem. Rev. 2004, 104, 3723. http://dx.doi.org/10.1021/cr030206t

PMid:15352778

64. Saji, T., In Phthalocyanines: Properties and Applications; Leznoff, C. C,; Lever, A. B. P. Eds.; VCH Publ. Inc.: New York, 1993; Vol. 2, p. 163.

65. Cook, M. J. Pure Appl. Chem. 1999, 71, 2145. http://dx.doi.org/10.1351/pac199971112145

66. Cook, M. J.; Chambrier, I. In Porphyrin Handbook; Kadish, K. M.; Smith, K. M.; Guilard, R. Eds.; Academic Press: San Diego, 2003; Vol. 17, p. 37. http://dx.doi.org/10.1016/B978-0-08-092391-8.50008-X

67. Rodriguez-Morgade, M. S.; de la Torre, G.; Torres, T. In Porphyrin Handbook; Kadish, K. M.; Smith, K. M.; Guilard, R. Eds.; Academic Press: San Diego, 2003; Vol. 15, p. 125. http://dx.doi.org/10.1016/B978-0-08-092389-5.50009-2

68. de la Torre, G.; Torres, T. J. Porphyrins Phthalocyanines 2002, 6, 274. http://dx.doi.org/10.1142/S1088424602000324

69. de la Torre, G.; Claessens, C. G.; Torres, T. Eur. J. Org. Chem. 2000, 2821. http://dx.doi.org/10.1002/1099-0690(200008)2000:16<2821::AID-EJOC2821>3.0.CO;2-2

70. Kobayashi, N.; Inagaki, S.; Nemykin, V. N.; Nonomura, T. Angew. Chem. Int. Ed. 2001, 40, 2710.

http://dx.doi.org/10.1002/1521-3773(20010716)40:14<2710::AID-ANIE2710>3.0.CO;2-A

71. Fernandez-Lazaro, F.; Torres, T.; Hauschel, B.; Hanack, M. Chem. Rev. 1998, 98, 563. http://dx.doi.org/10.1021/cr970002a

PMid:11848908

72. Islyaikin, M. K.; Danilova, E. A.; Yagodarova, L. D.; Rodriguez-Morgade, M. S.; Torres, T. Org. Lett. 2001, 3, 2153. http://dx.doi.org/10.1021/o10159241

PMid:11440567

73. Durfee, W. S.; Ziegler, C. J. J. Porphyrins Phthalocyanines 2009, 13, 304. http://dx.doi.org/10.1142/S1088424609000413

74. Ziegler, C. J. ACS Symposium Series 2009, 1012, 115.

75. Elvidge, J. A.; Linstead, R. P. J. Chem. Soc. 1955, 3536. http://dx.doi.org/10.1039/jr9550003536

76. Kopranenkov, V. N.; Tsygankova, A. M.; Luk'yanets, E. A. Anilinokras. prom.(Russ.) 1979, 5, 1.

77. Kobayashi, N.; Lam, H.; Nevin, W. A.; Janda, P.; Leznoff, C. C.; Lever, A. B. P. Inorg. Chem. 1990, 29, 3415. http://dx.doi.org/10.1021/ic00343a028 
78. Kobayashi, N.; Kondo, R.; Nakajima, S.; Osa, T. J. Am. Chem. Soc. 1990, 112, 9640. http://dx.doi.org/10.1021/ja00182a034

79. Kobayashi, N.; Ashida, T.; Hiroya, K.; Osa, T. Chem. Lett. 1992, 1567. http://dx.doi.org/10.1246/c1.1992.1567

80. Kobayashi, N.; Ashida, T.; Osa, T. Chem. Lett. 1992, 2031. http://dx.doi.org/10.1246/c1.1992.2031

81. Musluoglu, E.; Gurek, A.; Ahsen, V.; Gul, A.; Bekaroglu, O. Chem. Ber. 1992, 125, 2337. http://dx.doi.org/10.1002/cber.19921251023

82. Subbotin, N. B.; Nemykin, V. N.; Voloshin, Y. Z. Mendeleev Commun. 1993, 121. http://dx.doi.org/10.1070/MC1993v003n03ABEH000253

83. Kobayashi, N.; Ashida, T.; Osa, T.; Konami, H. Inorg. Chem. 1994, 33, 1735. http://dx.doi.org/10.1021/ic00087a003

84. Feucht, C.; Linssen, T.; Hanack, M. Chem. Ber. 1994, 127, 113. http://dx.doi.org/10.1002/cber.19941270119

85. Linssen, T. G.; Hanack, M. Chem. Ber. 1994, 127, 2051. http://dx.doi.org/10.1002/cber.19941271030

86. Nemykin, V. N.; Subbotin, N. B.; Kostromina, N. A.; Volkov, S. V. Mendeleev Commun. 1995, 71 . http://dx.doi.org/10.1070/MC1995v005n02ABEH000464

87. Nemykin, V. N.; Subbotin, N. B.; Kostromina, N. A.; Volkov, S. V.; Luk'yanets, E. A. Zh. Neorganicheskoi Khimii (Russ) 1995, 40, 1183. Chem. Abstr. 1995, 123, 245259.

88. Sastre, A.; Torres, T.; Hanack, M. Tetrahedron Lett. 1995, 36, 8501. http://dx.doi.org/10.1016/0040-4039(95)01781-C

89. Cook, M. J.; Daniel, M. F.; Harrison, K. J.; McKeown, N. B.; Thomson, A. J. J. Chem. Soc. Chem. Commun. 1987, 1148. http://dx.doi.org/10.1039/c39870001148

90. McKeown, N. B.; Chambrier, I.; Cook, M. J. J. Chem. Soc. Perkin Trans I 1990, 1169

91. Chambrier, I.; Cook, M. J.; Cracknell, S. J.; McMurdo, J. J. Mater. Chem. 1993, 3, 841. http://dx.doi.org/10.1039/jm9930300841

92. Bryant, G. C.; Cook, M. J.; Haslam, S. D.; Richardson, R. M.; Ryan, T. G.; Thorne, A. J. J. Mater. Chem. 1994, 4, 209. http://dx.doi.org/10.1039/jm9940400209

93. Leznoff, C. C.; Hall, T. W. Tetrahedron Lett. 1982, 23, 3023. http://dx.doi.org/10.1016/S0040-4039(00)87523-1

94. Hall, T. W.; Greenberg, S.; McArthur, C. R.; Khouw, B.; Leznoff, C. C. Nouv. J. Chim. 1982, 6, 653.

95. Leznoff, C. C.; Svirskaya, P. I.; Khouw, B.; Cerny, R. L.; Seymour, P.; Lever, A. B. P. J. Org. Chem. 1991, 56, 82.

http://dx.doi.org/10.1021/jo00001a019 
96. Vigh, S.; Lam, H.; Janda, P.; Lever, A. B. P.; Leznoff, C. C.; Cerny, R. L. Can. J. Chem. 1991, 69, 1457.

http://dx.doi.org/10.1139/v91-215

97. Young, J. G.; Onyebuagu, W. J. Org. Chem. 1990, 55, 2155.

http://dx.doi.org/10.1021/jo00294a032

98. Leznoff, C. C.; Greenberg, S.; Khouw, B.; Lever, A. B. P. Can. J. Chem. 1987, 65, 1705. http://dx.doi.org/10.1139/v87-285

99. Ando, M.; Mori, Y. 56th Annual Meeting, Chemical Society of Japan, Tokyo, Japan, 1988: Abstract No. 3VA01.

100. Kobayashi, N.; Kondo, R.; Nakajima, S.-I.; Osa, T. J. Am. Chem. Soc. 1990, 112, 9640. http://dx.doi.org/10.1021/ja00182a034

101. Leznoff, C. C. Can. J. Chem. 2000, 78, 167.

102. Torres, T. J. Porphyrins Phthalocyanines 2000, 4, 325. http://dx.doi.org/10.1002/(SICI)1099-1409(200006/07)4:4<325::AID-JPP225>3.0.CO;2-I

103. Tolbin, A. Yu; Tomilova, L. G.; Zefirov, N. S. Russ. Chem. Rev. 2007, 76, 681. http://dx.doi.org/10.1070/RC2007v076n07ABEH003698

104. Mack, J.; Kobayashi, N. Chem. Rev. 2011, 111, 281. http://dx.doi.org/10.1021/cr9003049

PMid:21175133

105. Makarov, S. G.; Suvorova, O. N.; Wöhrle D. J. Porphyrins Phthalocyanines 2011, 15, 791. http://dx.doi.org/10.1142/S1088424611003835

106. Dumoulin, F.; Ahsen, V. J. Porphyrins Phthalocyanines 2011, 15, 481. http://dx.doi.org/10.1142/S1088424611003434

107. Wang, A.; Long, L.; Zhang, C. Tetrahedron 2012, 68, 2433. http://dx.doi.org/10.1016/j.tet.2012.01.004

108. Hah, U.; Rodriguez-Morgade, M. S. J. Porphyrins Phthalocyanines 2009, 13, 455. http://dx.doi.org/10.1142/S1088424609000644

109. Bakboord, J. V.; Cook, M. J.; Hamuryudan, E. J. Porphyrins Phthalocyanines 2000, 4, 510. http://dx.doi.org/10.1002/1099-1409(200008)4:5<510::AID-JPP278>3.0.CO;2-4

110. Cook, M. J.; Jafari-Fini, A. Tetrahedron 2000, 56, 4085. http://dx.doi.org/10.1016/S0040-4020(00)00323-9

111. Cook, M. J.; Heeney, M. J. Chem. Eur. J. 2000, 6, 3958. http://dx.doi.org/10.1002/1521-3765(20001103)6:21<3958::AID-CHEM3958>3.0.CO;2-Y

112. Cammidge, A. N.; Goddard, V. H. M.; Will, G.; Arnold, D. P.; Cook, M. J. Tetrahedron Lett. 2009, 50, 3013. http://dx.doi.org/10.1016/j.tetlet.2009.03.193

113. Kumru, U.; Ermeydan, M. A.; Dumoulin, F.; Ahsen V. J. Porphyrins Phthalocyanines 2008, 12, 1090. http://dx.doi.org/10.1142/S1088424608000443 
114. Ermeydan, M. A.; Fabienne Dumoulin, F.; Basova, T. V.; Bouchu, D.; Gürek A.G.; Ahsen, V.; Lafont, D. New J. Chem., 2010, 34, 1153.

http://dx.doi.org/10.1039/b9nj00634f

115. Zorlu, Y.; Dumoulin , F.; Bouchu , D.; Ahsen ,V.; Lafont, D. Tetrahedron Lett., 2010,51, 6615.

http://dx.doi.org/10.1016/j.tetlet.2010.10.044

116. Lafont, D; Zorlu, Y.; Savoie, H.; Albrieux, F.; Ahsen, V.; Boyle, R. W.; Dumoulin, F.; Photodiagnosis and Photodynamic Therapy 2013, 10, 252.

http://dx.doi.org/10.1016/j.pdpdt.2012.11.009

PMid:23993851

117. Tuncel, S.; Trivella, A.; Atilla, D.; Bennis, K.; Savoie, H.; Albrieux, F.; Delort, L.; Billard, H.; Dubois, V.; Ahsen, V.; Caldefie-Chézet, F.; Richard, C.; Boyle, R. W.; Ducki, S.;

Dumoulin, F.; Mol. Pharmaceutics

http://dx.doi.org/10.1021/mp400207v.

118. Makarova, E. A.; Koroleva, G. V.; Luk'yanets, E. A. Russ. J. Gen. Chem. 2001, 71, 821. http://dx.doi.org/10.1023/A:1012398427529

119. Makarova, E. A.; Koroleva, G. V.; Luk'yanets, E. A. RU Patent 2188200, 2002; Chem. Abstr. 2003, 138, 368675c.

120. Fukuda, T.; Makarova, E. A.; Luk'yanets, E. A.; Kobayashi, N. Chem. Eur. J. 2004, 10, 117.

http://dx.doi.org/10.1002/chem.200305363

PMid:14695557

121. Makarova, E. A.; Fukuda, T.; Luk'yanets, E. A.; Kobayashi, N. Chem. Eur. J. 2005, 11, 1235 .

http://dx.doi.org/10.1002/chem.200400845

PMid:15625670

122. Makarova, E. A.; Dzyuina, E. V.; Luk'yanets, E. A. Rus. J. Gen. Chem. 2006, 76, 1165. http://dx.doi.org/10.1134/S1070363206070280

123. Makarova, E. A.; Dzyuina, E. V.; Fukuda, T.; Kaneko, H.; Hashimoto, N.; Kikukawa, Y.; Kobayashi, N.; Lukyanets, E. A. Inorg. Chem. 2009, 48, 164.

http://dx.doi.org/10.1021/ic801552u

PMid:19049420

124. Dudkin, S. V.; Kobzeva, E. S.; Luk'yanets, E. A.; Makarova, E. A. RU Patent 2479586, 2013; Chem. Abstr. 2013, 158, 534643.

125. Makarova, E. A.; Dudkin, S. V.; Lukyanets, E. A. J. Porphyrins Phthalocyanines 2013, 17, 785 . http://dx.doi.org/10.1142/S1088424613500338

126. Fukuda, T.; Masuda, S.; Kobayashi, N. J. Am. Chem. Soc. 2007, 129, 5472. http://dx.doi.org/10.1021/ja0678323

PMid:17411037 
127. Fukuda, T.; Masuda, S.; Hashimoto, N.; Kobayashi, N. Inorg. Chem. 2008, 47, 2576. http://dx.doi.org/10.1021/ic701840r

PMid:18327902

128. Fukuda, T.; Sugita, I.; Kobayashi, N. Chem. Commun. 2009, 3449. http://dx.doi.org/10.1039/b902982f

PMid:19503900

129. Ozoemena, K. I.; Mamuru, S. A.; Fukuda, T.; Kobayashi, N.; Nyokong, T. Electrochem. Commun. 2009, 11, 1221. http://dx.doi.org/10.1016/j.elecom.2009.04.011

130. Fukuda, T.; Kaneko, H.; Kobayashi, N. J. Porphyrins Phthalocyanines 2009, 13, 999. http://dx.doi.org/10.1142/S1088424609001327

131. Nemykin, V. N.; Kobayashi, N.; Nonomura, T.; Luk'yanets, E. A. Chem. Lett. $2000,184$. http://dx.doi.org/10.1246/c1.2000.184

132. Mikhalenko, S. A.; Luk'yanets, E. A. Zh. Organicheskoi Khimii 1970, 6, 171. Chem. Abstr. 1970, 72, 112781.

133. Hirth, A.; Sobbi, A. K.; Woehrle D. J. Porphyrins Phthalocyanines 1997, 1, 275. http://dx.doi.org/10.1002/(SICI)1099-1409(199707)1:3<275::AID-JPP30>3.0.CO;2-Q

134. Lam, H.; Marcuccio, S. M.; Svirskaya, P. I.; Greenberg, S.; Lever, A. B. P.; Leznoff, C. C.; Cerny, R. L. Can. J. Chem. 1989, 67, 1087. http://dx.doi.org/10.1139/v89-164

135. Gonzalez, A.; Varquez, P.; Torres T. Tetrahedron Lett. 1999, 40, 3263. http://dx.doi.org/10.1016/S0040-4039(99)00379-2

136. Tolbin, A. Yu.; Pushkarev, V. E.; Shulishov, E. V.; Ivanov, A. V.; Tomilova, L. G.; Zefirov, N. S. Mendeleev Commun. 2005, 24. http://dx.doi.org/10.1070/MC2005v015n01ABEH001934

137. Nemykin, V. N.; Koposov, A. Y.; Subbotin, R. I.; Sharma, S. Tetrahedron Lett. 2007, 48, 5425 . http://dx.doi.org/10.1016/j.tetlet.2007.06.016

138. Asano, Y.; Muranaka, A.; Fukasawa, A.; Hatano, T.; Uchiyama, M.; Kobayashi, N. J. Am. Chem. Soc. 2007, 129, 4516.

http://dx.doi.org/10.1021/ja068528c

PMid: 17385857

139. Makarov, S. G.; Suvorova, O. N.; Litwinski, C.; Ermilov, E. A.; Roeder, B.; Tsaryova, O.; Duelcks, T.; Woehrle, D. Eur. J. Inorg. Chem. 2007, 546. http://dx.doi.org/10.1002/ejic.200600843

140. Lelievre, D.; Bosio, L.; Simon, J.; Andre, J. J.; Bensebaa, F. J. Am. Chem. Soc. 1992, 114, 4475. http://dx.doi.org/10.1021/ja00038a005

141. Lelievre, D.; Damette, O.; Simon, J. J. Chem. Soc. Chem. Commun. 1993, 939. 
142. Ishii, K.; Kobayashi, N.; Higashi, Y.; Osa, T.; Lelievre, D.; Simon, J.; Yamauchi, S. Chem. Commun. 1999, 969.

http://dx.doi.org/10.1039/a900347i

143. Kobayashi, N.; Higashi, Y.; Osa, T. J. Chem. Soc. Chem. Commun. 1994, 1785. http://dx.doi.org/10.1039/c39940001785

144. Kobayashi, N.; Fukuda, T.; Lelievre, D. Inorg. Chem. 2000, 39, 3632.

http://dx.doi.org/10.1021/ic991496s

PMid:11196826

145. Kobayashi, N.; Ogata, H. Eur. J. Inorg. Chem. 2004, 906. http://dx.doi.org/10.1002/ejic.200300536

146. Asano, Y.; Sato, J.; Furuyama, T.; Kobayashi, N. Chem. Commun. 2012, 48, 4365. http://dx.doi.org/10.1039/c2cc31264f

PMid:22447315

147. Maksimov, A. Yu.; Ivanov, A. V.; Blikova, Y. N.; Tomilova, L. G.; Zefirov, N. S. Mendeleev Commun. 2003, 70. http://dx.doi.org/10.1070/MC2003v013n02ABEH001668

148. Tolbin, A. Yu.; Pushkarev, V. E.; Tomilova, L. G.; Zefirov, N. S. Russ. Chem. Bull. 2006, $55,1155$. http://dx.doi.org/10.1007/s11172-006-0392-y

149. Tolbin, A. Yu.; Pushkarev, V. E.; Tomilova, L. G.; Zefirov, N. S. J. Porphyrins Phthalocyanines 2008, 12, 1187. http://dx.doi.org/10.1142/S108842460800056X

150. Dubinina, T. V.; Ivanov, A. V.; Borisova, N. E.; Trashin, S. A.; Gurskiy, S. I.; Tomilova, L. G.; Zefirov, N. S. Inorg. Chim. Acta 2010, 363, 1869. http://dx.doi.org/10.1016/j.ica.2010.02.011

151. Tolbin, A. Yu.; Pushkarev, V. E.; Tomilova, L. G.; Zefirov, N. S. Macroheterocycles 2010, 3,30 .

152. Dubinina, T. V.; Borisova, N. E.; Paramonova, K. V.; Tomilova, L. G. Mendeleev Commun. 2011, 21, 165. http://dx.doi.org/10.1016/j.mencom.2011.04.019

153. Trashin, S. A.; Dubinina, T. V.; Fionov, A. V.; Tomilova, L. G. J. Porphyrins Phthalocyanines 2011, 15, 1195. http://dx.doi.org/10.1142/S1088424611004105

154. Dubinina, T. V.; Trashin, S. A.; Borisova, N. E.; Boginskaya, I. A.; Tomilova, L. G.; Zefirov, N. S. Dyes Pigments 2012, 93, 1471. http://dx.doi.org/10.1016/j.dyepig.2011.10.012

155. Leznoff, C. C.; Drew, D. M. Can. J. Chem. 1996, 74, 307. http://dx.doi.org/10.1139/v96-035

156. Miwa, H.; Kobayashi, N. Chem. Lett. 1999, 1303. http://dx.doi.org/10.1246/cl.1999.1303 
157. Kobayashi, N.; Miwa, H.; Nemykin, V. N. J. Am. Chem. Soc. 2002, 124, 8007. http://dx.doi.org/10.1021/ja0123812

158. Seotsanyana-Mokhosi, I.; Nyokong, T. J. Porphyrins Phthalocyanines 2004, 8, 1214. http://dx.doi.org/10.1142/S1088424604000568

159. Seotsanyana-Mokhosi, I.; Chen, J.-Y.; Nyokong, T. J. Porphyrins Phthalocyanines 2005, 9, 316. http://dx.doi.org/10.1142/S108842460500040X

160. Seotsanyana-Mokhosi, I.; Nyokong, T. J. Porphyrins Phthalocyanines 2005, 9, 476. http://dx.doi.org/10.1142/S1088424605000599

161. Lv, W.; Zhang, X.; Lu, J.; Zhang, Y.; Li, X.; Jiang, J. Eur. J. Inorg. Chem. 2008, 4255. http://dx.doi.org/10.1002/ejic.200800546

162. Dudkin, S. V.; Makarova, E. A.; Fukuda, T.; Kobayashi, N.; Lukyanets, E. A. Tetrahedron Lett. 2011, 52, 2994. http://dx.doi.org/10.1016/j.tetlet.2011.03.145

163. Kudrik, E. V.; Nikolaev, I. U.; Shaposhnikov, G. P.; Usol'tseva, N. V.; Bykova, V. V. Mendeleev Commun. 2000, 222. http://dx.doi.org/10.1070/MC2000v010n06ABEH001306

164. Idelson, E. M. U.S. Patent 4061 654, 1977; Chem. Abstr. 1977, 88, 171797m.

165. Dabak, S.; Bekaroğlu, O. J. Chem. Res. (S) 1997, 8.

166. Dabak, S.; Bekaroğlu, O. New J. Chem. 1997, 21, 267.

167. Stihler, P.; Hauschel, B.; Hanack M. Chem. Ber. 1997, 130, 801. http://dx.doi.org/10.1002/cber.19971300620

168. Hanack, M.; Stihler, P. Eur. J. Org. Chem. 2000, 303. http://dx.doi.org/10.1002/(SICI)1099-0690(200001)2000:2<303::AIDEJOC303>3.0.CO;2-M

169. Altindal, A.; Ozturk, Z. Z.; Dabak, S.; Bekaroglu, O. Sensor Actuat. B-Chem. 2001, 77, 389.

170. Agirtas, M. S.; Sonmez, M.; Kandaz, M.; Bekaroglu, O. Indian J. Chem. Sect. B 2001, 40B, 1236; Chem. Abstr. 2001,136, 340662.

171. Kandaz, M.; Michel, S. L. J.; Hoffman, B. M. J. Porphyrins Phthalocyanines 2003, 7, 700. http://dx.doi.org/10.1142/S1088424603000872

172. Wang, J.-D.; Lin, M.-J.; Wu, S.-F.; Lin, Y. J. Organometal. Chem. 2006, 691, 5074. http://dx.doi.org/10.1016/j.jorganchem.2006.08.066

173. Youngblood, W. J. J. Org. Chem. 2006, 71, 3345. http://dx.doi.org/10.1021/jo0521221

PMid:16626113

174. Lin, M.-J.; Wang, J.-D. J. Mol. Struct. 2007, 837, 284. http://dx.doi.org/10.1016/j.molstruc.2006.10.042

175. Dumoulin, F.; Zorlu, Y.; Ayhan, M. M.; Hirel, C.; Isci, U.; Ahsen, V. J. Porphyrins Phthalocyanines 2009, 13, 161. 


\section{http://dx.doi.org/10.1142/S1088424609000140}

176. Nemykin, V. N.; Rohde, G. T.; Barrett, C. D.; Hadt, R. G.; Sabin, J. R.; Reina, G.; Galloni, P.; Floris, B. Inorg. Chem. 2010, 49, 7497. http://dx.doi.org/10.1021/ic101012a

PMid:20690759

177. Lindsey, J. S. In Porphyrin Handbook; Kadish, K. M.; Smith, K. M.; Guilard, R. Eds.; Academic Press: San Diego, 2000; Vol. 1, p. 45.

178. Smith, K. M.; Vicente, M. G. H. In Science of Synthesis; George Thieme Verlag: Stuttgart, 2004; Vol. 17, p. 1081.

179. Cavaleiro, J. A. S.; Tome, A. C.; Neves, M. G. P. M. S. In Handbook of porphyrin science; Kadish, K. M.; Smith, K. M.; Guilard, R. Eds.; World Scientific Publ.: Singapore, 2010; Vol. 2, p. 193.

180. Oliver, S. W.; Smith, T. D. J. Chem. Soc. Perkin. Trans. 2 1987, 1579. http://dx.doi.org/10.1039/p29870001579

181. Nolan, K. J. M.; Hu, M.; Leznoff, C. C. Synlett 1997, 593. http://dx.doi.org/10.1055/s-1997-3226

182. Fukuda, T.: Kobayash, N. Chem. Lett. 2002, 866. http://dx.doi.org/10.1246/c1.2002.866

183. Claessens, C. G.; Gonzalez-Rodriguez, D.; Torres, T. Chem. Rev. 2002, 102, 835. http://dx.doi.org/10.1021/cr0101454 PMid:11890759

184. Ando, M.; Mori, Y. Jpn. Kokai Tokkyo Koho JP 0209882 [90 09 882], 1990; Chem. Abstr. 1990, 113, 25558c.

185. Musluoğlu, E.; Gürek, A.; Ahsen, V.; Gül, A.; Bekaroğlu, Ö. Chem. Ber. 1992, 125, 2337. http://dx.doi.org/10.1002/cber.19921251023

186. Gürek, A. G.; Bekaroğlu, Ö. J. Porphyrins and Phthalocyanines 1997, 1, 67. http://dx.doi.org/10.1002/(SICI)1099-1409(199701)1:1<67::AID-JPP8>3.0.CO;2-R

187. Gürek,A.G.; Bekaroğlu, Ö. J. Porphyrins and Phthalocyanines 1997, 1, 227. http://dx.doi.org/10.1002/(SICI)1099-1409(199707)1:3<227::AID-JPP17>3.0.CO;2-K

188. Kasuga, K.; Idehara, T.; Handa, M. Inorg. Chim. Acta 1992, 196, 127. http://dx.doi.org/10.1016/S0020-1693(00)86113-7

189. Dabak, S.; Gül, A.; Bekaroğlu, O. Chem. Ber. 1994, 127, 2009. http://dx.doi.org/10.1002/cber.19941271025

190. Sastre, A.; Torres, T.; Hanack, M. Tetrahedron Lett. 1995, 36, 8501. http://dx.doi.org/10.1016/0040-4039(95)01781-C

191. Kudrevich, S. V.; Gilbert, S.; van Lier, J. E. J. Org. Chem. 1996, 61, 5706. http://dx.doi.org/10.1021/jo9605354

192. Sastre, A.; del Rey, B.; Torres, T. J. Org. Chem. 1996, 61, 8591. http://dx.doi.org/10.1021/jo9610180 
193. Kudrevich, S.; Brasseur, N.; La Madeleine, C.; Gilbert, S.; van Lier, J. E. J. Med. Chem. 1997, 40, 3897. http://dx.doi.org/10.1021/jm9702488

PMid:9397170

194. Ali, H.; Sim, S.K.; van Lier, J. E. J. Chem. Res. (S), 1999, 496.

195. Kobayashi, N.; Ishizaki, T.; Ishii, K.; Konami, H. J. Am. Chem. Soc. 1999, 121, 9096. http://dx.doi.org/10.1021/ja983325c

196. Kimura, M.; Wada, K.; Ohta, K.; Hanabusa, K.; Shirai, H.; Kobayashi, N. Macromolecules 2001, 34. 4706. http://dx.doi.org/10.1021/ma010163n

197. Matlaba, P.; Nyokong, T. Polyhedron 2002, 21, 2463. http://dx.doi.org/10.1016/S0277-5387(02)01226-3

198. Sharman, W. M.; van Lier, J. E. Bioconjugate Chem. 2005, 16, 1166. http://dx.doi.org/10.1021/bc0500241 PMid:16173794

199. Vagin, S. I.; Frickenschmidt, A.; Kammerer, B.; Hanack, M. Eur. J. Chem. 2005, 11, 6568. http://dx.doi.org/10.1002/chem.200500705

PMid:16106461

200. Sharman, W. M.; van Lier, J. E. J. Porphyrins Phthalocyanines 2005, 9, 651. http://dx.doi.org/10.1142/S1088424605000769

201. Chauhan, S. M. S.; Kumari, P. Tetrahedron 2009, 65, 2518. http://dx.doi.org/10.1016/j.tet.2009.01.046

202. Tempesti, T. C.; Alvarez, M. G.; Durantini, E. N. Dyes Pigments 2011, 91, 6. http://dx.doi.org/10.1016/j.dyepig.2011.02.004

203. Ochoa, A. L.; Tempesti, T. C.; Spesia, M. B.; Milanesio, M. E.; Durantini, E. N. Eur. J. Med. Chem. 2012, 50, 280. http://dx.doi.org/10.1016/j.ejmech.2012.02.005 PMid:22365412

204. Weitemeyer, A.; Kliesch, H.; Woehrle, D. J. Org. Chem. 1995, 60, 4900. http://dx.doi.org/10.1021/jo00120a038

205. Feucht, C.; Linssen, T.; Hanack, M. Chem. Ber. 1994, 127, 113. http://dx.doi.org/10.1002/cber.19941270119

206. Rack, M.; Hauschel, B.; Hanack, M. Chem. Ber. 1996, 129, 237. http://dx.doi.org/10.1002/cber.19961290220

207. Jung, R; Hanack, M. Synt. Metal. 1999, 102, 1526. http://dx.doi.org/10.1016/S0379-6779(98)90016-9

208. Hauschel, B.; Jung, R.; Hanack, M. Eur. J. Inorg. Chem. 1999, 693. http://dx.doi.org/10.1002/(SICI)1099-0682(199904)1999:4<693::AID-EJIC693>3.0.CO;2Q

209. Durr, K.; Fiedler, S.; Linssen, T.; Hirsch, A.; Hanack, M. Chem. Ber. 1997, 130, 1375. 
http://dx.doi.org/10.1002/cber.19971301005

210. Fukuda, T.; Hashimoto, N.; Araki, Y.; El-Khouly, M. E.; Ito, O.; Kobayashi, N. Chem.

Asian J. 2009, 4, 1678.

http://dx.doi.org/10.1002/asia.200900241

PMid:19866461

211. Youssef, T. E.; Hanack, M. J. Porphyrins Phthalocyanines 2005, 9, 28. http://dx.doi.org/10.1142/S108842460500006X

212. Nemykin, V. N.; Polshina, A. E.; Kobayashi, N. Chem. Lett. 2000, 1236. http://dx.doi.org/10.1246/c1.2000.1236

213. Makarova, E. A.; Korolyova, G. V.; Tok, O. L.; Lukyanets, E. A. J. Porphyrins Phthalocyanines 2000, 4, 525.

http://dx.doi.org/10.1002/1099-1409(200008)4:5<525::AID-JPP280>3.0.CO;2-B

214. Silva, A. M. G.; Lacerda, P. S. S.; Tome, A. C.; Neves, M. G. P. M. S.; Silva, A. M. S.; Cavaleiro, J. A. S.; Makarova, E. A.; Lukyanets, E. A. J. Org. Chem. 2006, 71, 8352. http://dx.doi.org/10.1021/jo0611770

PMid:17064004

215. Makarova, E. A.; Lukyanets, E. A. J. Porphyrins Phthalocyanines 2009, 13, 188. http://dx.doi.org/10.1142/S1088424609000310

216. Dudkin, S. V.; Makarova, E. A.; Luk'yanets, E. A. Russ. J. Gen. Chem. 2008, 78, 1441. http://dx.doi.org/10.1134/S1070363208070281

217. Maya, E. M.; Vazguez, P.; Torres, T. Chem. Commun. 1997, 1175. http://dx.doi.org/10.1039/a701991b

218. Ali, H.; van Lier, J. E. Tetrahedron Lett. 1997, 38, 1157. http://dx.doi.org/10.1016/S0040-4039(97)00013-0

219. Maya, E. M.; Vazguez, P.; Torres, T. Chem. Eur. J. 1999, 5, 2004. http://dx.doi.org/10.1002/(SICI)1521-3765(19990702)5:7<2004::AIDCHEM2004>3.0.CO;2-P

220. Sharman, W. M.; van Lier, J. E. J. Porphyrins Phthalocyanines 2000, 4, 441. http://dx.doi.org/10.1002/1099-1409(200008)4:5<441::AID-JPP275>3.0.CO;2-A

221. Gouloumis, A.; Liu, S.-G.; Sastre, A.; Vazquez, P.; Echegoyen, L.; Torres, T. Chem. Eur. J. 2000, 6, 3600.

http://dx.doi.org/10.1002/1521-3765(20001002)6:19<3600::AID-CHEM3600>3.3.CO;2-S

222. Jung, R.; Schweikart, K.-H.; Hanack, M. Eur. J. Org. Chem. 1999, 1687. http://dx.doi.org/10.1002/(SICI)1099-0690(199907)1999:7<1687::AIDEJOC1687>3.0.CO;2-Y

223. Tian, H.; Ali, H.; van Lier, J. E. Tetrahedron Lett. 2000, 41, 8435. http://dx.doi.org/10.1016/S0040-4039(00)01531-8

224. Cook, M. J.; Heeney, M. J. Chem. Commun. 2000, 969. http://dx.doi.org/10.1039/b001783n 
225. Cook, M. J.; Heeney, M. J. Chem. Eur. J. 2000, 6, 3958.

http://dx.doi.org/10.1002/1521-3765(20001103)6:21<3958::AID-CHEM3958>3.0.CO;2-Y

226. Maya, E. M.; Vazguez, P.; Torres, T.; Gobbi, L.; Diederich, F.; Pyo, S.; Echegoyen, L. J.

Org. Chem. 2000, 65, 823.

http://dx.doi.org/10.1021/jo991505e

227. Maya, E. M.; Garsia, C.; Garsia-Frutos, E. M.; Vazguez, P.; Torres, T. J. Org. Chem. 2000, 65, 2733.

http://dx.doi.org/10.1021/jo991843f

228. Tian, M.; Wada, T.; Sasabe, H. J. Heterocycl. Chem. 2000, 37, 1193.

http://dx.doi.org/10.1002/jhet.5570370528

229. Garcia-Frutos, E. M.; Fernandez-Lazaro, F.; Maya, E. M.; Vazquez, P.; Torres, T. J.

Organic Chem. 2000, 65, 6841.

http://dx.doi.org/10.1021/jo0006019

230. Gouloumis, A.; Vazquez, P.; Torres, T.; Liu, S.-G.; Echegoyen, L. Chem. Commun. 2001, 399.

http://dx.doi.org/10.1039/b009917c

231. Gonzalez-Cabello, A.; Vazquez, P.; Torres, T. J. Organometal. Chem. 2001, 637-639, 751. http://dx.doi.org/10.1016/S0022-328X(01)00906-8

232. de la Escosura, A.; Martinez-Diaz, M. V.; Thordarson, P.; Rowan, A. E.; Nolte, R. J. M.;

Torres, T. J. Am. Chem. Soc. 2003, 125, 12300.

http://dx.doi.org/10.1021/ja030038m

PMid:14519015

233. Garcia-Frutos, E. M.; O'Flaherty, S. M.; Maya, E. M.; de la Torre, G.; Blau, W.; Vazquez, P.; Torres, T. J. Mater. Chem. 2003, 13, 749.

http://dx.doi.org/10.1039/b210707d

234. Tian, M.; Zhang, Y.; Wada, T.; Sasabe, H. Dyes Pigment. 2003, 58, 135.

http://dx.doi.org/10.1016/S0143-7208(03)00062-7

235. Gonzalez-Rodriguez, D.; Claessens, C. G.; Torres, T.; Liu, S.; Echegoyen, L.; Vila, N.;

Nonell, S. Chem. Eur. J. 2005, 11, 3881.

http://dx.doi.org/10.1002/chem.200400779

PMid:15827986

236. Ali, H.; St-Jean, O.; Tremblay-Morin, J.-P.; van Lier, J. E. Tetrahedron Lett. 2006, 47, 8275.

http://dx.doi.org/10.1016/j.tetlet.2006.09.101

237. Ali, H.; Baillargeon, P.; van Lier, J. E. Tetrahedron Lett. 2008, 49, 7253.

http://dx.doi.org/10.1016/j.tetlet.2008.09.160

238. Quintiliani, M.; Garcia-Frutos, E. M.; Vazquez, P.; Torres, T. J. Inorg. Biochem. 2008, 102, 388.

http://dx.doi.org/10.1016/j.jinorgbio.2007.10.025

PMid:18164762 
239. Ali, H.; van Lier, J. E. Tetrahedron Lett. 2009, 50, 337. http://dx.doi.org/10.1016/j.tetlet.2008.11.035

240. Dumoulin, F.; Ali, H.; Ahsen, V.; van Lier, J. E. Tetrahedron Lett. 2011, 52, 4395. http://dx.doi.org/10.1016/j.tetlet.2011.06.010

241. Ali, H.; Ait-Mohand, S.; Gosselin, S.; van Lier, J. E.; Guerin, B. J. Org. Chem. 2011, 76, 1887.

http://dx.doi.org/10.1021/jo102083g

PMid:21302913

242. Ranyuk, E.; Cauchon, N.; Klarskov, K.; Guerin, B.; van Lier, J. E. J. Med. Chem. 2013, 56, 1520.

http://dx.doi.org/10.1021/jm301311c

PMid:23356907

243. Ali, H.; van Lier, J. E. Tetrahedron Lett. 2013, 54, 2956. http://dx.doi.org/10.1016/j.tetlet.2013.03.108

244. Gouterman, M.; Hall, R. J.; Khalil, G. E.; Martin, P. C.; Shankland, E. G.; Cerny, R. L. J. Am. Chem. Soc. 1989, 111, 3702. http://dx.doi.org/10.1021/ja00192a030

245. Brückner, C.; Dolphin, D. Tetrahedron Lett. 1995, 36, 3295. http://dx.doi.org/10.1016/0040-4039(95)00524-G

246. Brückner, C.; Rettig, S. J.; Dolphin, D. J. Org. Chem. 1998, 63, 2094. http://dx.doi.org/10.1021/jo971156t

247. Brueckner, C.; Sternberg, E. D.; MacAlpine, J. K.; Rettig, S. J.; Dolphin, D. J. Am. Chem. Soc. 1999, 121, 2609. http://dx.doi.org/10.1021/ja981417w

248. Khalil, G.; Gouterman, M.; Ching, S.; Costin, C.; Coyle, L.; Gouin, S.; Green, E.; Sadilek, M.; Wan, R.; Yearyean, J.; Zelelow, B. J. Porphyrins Phthalocyanines 2002, 6, 135. http://dx.doi.org/10.1142/S108842460200018X

249. Lara, K. K.; Rinaldo, C. R.; Brückner, C. Tetrahedron 2005, 61, 2529. http://dx.doi.org/10.1016/j.tet.2004.12.043

250. Banerjee, S.; Zeller, M.; Brückner, C. J. Org. Chem. 2009, 74, 4283. http://dx.doi.org/10.1021/jo9005443

PMid:19422187

251. Akhigbe, J.; Ryppa, C.; Zeller, M.; Brückner, C. J. Org. Chem. 2009, 74, 4927. http://dx.doi.org/10.1021/jo9006046

PMid:19489565

252. Banerjee, S.; Zeller, M.; Brückner, C. J. Org. Chem. 2010, 75, 1179. http://dx.doi.org/10.1021/jo9024286

PMid:20067246

253. Banerjee, S.; Hyland, M A.; Brückner, C. Tetrahedron Lett 2010, 51, 4505. http://dx.doi.org/10.1016/j.tetlet.2010.06.096 
254. Akhigbe, J.; Haskoor, J.; Zeller, M.; Brückner, C. Chem. Commun. 2011, 47, 8599. http://dx.doi.org/10.1039/c1cc12955d

PMid:21713296

255. Ogikubo, J.; Meehan, E.; Engle, J. T.; Ziegler, C J.; Brückner, C. J. Org. Chem. 2013, 78, 2840.

http://dx.doi.org/10.1021/jo400031r

PMid:23421329

256. Mani, N. S.; Beall, L. S.; White, A. J. P.; Williams, D. J.; Barrett, A. G. M.; Hoffman, B. M. J. Chem. Soc. Chem. Commun. 1994, 1943.

257. Montalban, A. G.; Lange, S. J.; Beall, L. S.; Mani, N. S.; Williams, D. J.; White, A. J. P.; Barrett, A. G. M.; Hoffman, B. M. J. Org. Chem. 1997, 62, 9284. http://dx.doi.org/10.1021/jo971599x

258. Montalban, A. G; Baum, S. M.; Barrett, A. G. M.; Hoffman, B. M. Dalton Trans. 2003, 2093. http://dx.doi.org/10.1039/b209800h

259. Gonca, E.; Baklaci, U. G.; Dincer, H. A. Polyhedron 2008, 27, 2431. http://dx.doi.org/10.1016/j.poly.2008.04.025

260. Gonca, E.; Baklaci, U. G.; Dincer, H. A. J. Porphyrins Phthalocyanines 2008, 12, 116. http://dx.doi.org/10.1142/S1088424608000157

261. Altunkaya, M.; Gonca, E. Polyhedron 2011, 30, 1035. http://dx.doi.org/10.1016/j.poly.2011.01.003

262. Freyer, W.; Leupold, D. J. Photochem. Photobiol. A Chem. 1997, 105, 153. http://dx.doi.org/10.1016/S1010-6030(96)04550-9

263. Hedayatullah, M. Compt. Rend. Acad. Sci. Ser. II C 1983, 296, 621.

264. Chen, M. J.; Fendrick, C. M.; Watson, R. A.; Kitner, K. S.; Rathke, J. W. J. Chem. Soc. Perkin Trans. 1 1989, 1071.

265. Leznoff, C. C.; Sosa-Sanchez, J. L. Chem. Commun. 2004, 338. http://dx.doi.org/10.1039/b313253f

PMid:14740066

266. Leznoff, C. C.; Hiebert, A.; Ok, S. J. Porphyrins Phthalocyanines 2007, 11, 537. http://dx.doi.org/10.1142/S1088424607000631

267. Causey, P. W.; Dubovyk, I.; Leznoff, C. C. Can. J. Chem. 2006, 84, 1380. http://dx.doi.org/10.1139/v06-096

268. Baumann, T. F.; Sibert, J. W.; Olmstead, M. M.; Barrett, A. G. M.; Hoffman, B. M. J. Am. Chem. Soc. 1994, 116, 2639. http://dx.doi.org/10.1021/ja00085a062

269. Sibert, J. W.; Baumann, T. F.; Williams, D. J.; White, A. J. P.; Barrett, A. G. M.; Hoffman, B. M. J. Am. Chem. Soc. 1996, 118, 10487. http://dx.doi.org/10.1021/ja961912x

270. Baumann, T. F.; Barrett, A. G. M.; Hoffman, B. M. Inorg. Chem. 1997, 36, 5661. 
http://dx.doi.org/10.1021/ic9701367

271. Goldberg, D. P.; Michel, S. L. J.; White, A. J. P.; Williams, D. J.; Barrett, A. G. M.;

Hoffman, B. M. Inorg. Chem. 1998, 37, 2100.

http://dx.doi.org/10.1021/ic971498h

PMid:11670359

272. Lange, S. J.; Nie, H.; Stern, C. L.; Barrett, A. G. M.; Hoffman, B. M. Inorg. Chem. 1998, 37,6435 .

http://dx.doi.org/10.1021/ic980791u

PMid:11670763

273. Kobayashi, N.; Muranaka, A.; Nemykin, V. N. Tetrahedron Lett. 2001, 42, 913. http://dx.doi.org/10.1016/S0040-4039(00)02134-1

274. Donzello, M. Pia; Vittori, D.; Viola, E.; Manet, I.; Mannina, L.; Cellai, L.; Monti, S.;

Ercolani, C. Inorg. Chem. 2011, 50, 7391.

http://dx.doi.org/10.1021/ic200498s

PMid:21770399

275. Nemykin, V. N.; Mytsyk, V. M.; Volkov, S. V.; Kobayashi, N. J. Porphyrins

Phthalocyanines 2000, 4, 551.

http://dx.doi.org/10.1002/1099-1409(200008)4:5<551::AID-JPP270>3.0.CO;2-L

276. Dolotova, O.; Kaliya, O. L. J. Porphyrins Phthalocyanines 2011, 15, 632. http://dx.doi.org/10.1142/S1088424611003550

277. Nemykin, V. N.; Polshyna, A. E.; Makarova, E. A.; Kobayashi, N.; Lukyanets, E. A. Chem. Commun. 2012, 48, 3650.

http://dx.doi.org/10.1039/c2cc30760j

PMid:22395412

278. Sugita, I.; Shimizu, S.; Fukuda, T.; Kobayashi, N. Tetrahedron Lett. 2013, 54, 1599. http://dx.doi.org/10.1016/j.tetlet.2013.01.057

279. Wong, E. W. Y.; Miura, A.; Wright, M. D.; He, Q.; Walsby, C. J.; Shimizu, S.; Kobayashi, N.; Leznoff, D. B. Chem. Eur. J. 2012, 18, 12404. http://dx.doi.org/10.1002/chem.201201701

PMid:22933175

280. Kingsborough, R. P.; Swager, T. M. Angew. Chem. Int. Ed. 2000, 39, 2897. http://dx.doi.org/10.1002/1521-3773(20000818)39:16<2897::AID-ANIE2897>3.0.CO;2-R

281. Ballesteros, B.; de la Torre, G.; Shearer, A.; Hausmann, A.; Herranz, M. A.; Guldi, D. M.; Torres, T. Chem. Eur. J. 2010, 16, 114. http://dx.doi.org/10.1002/chem.200902200

PMid:19998436

282. Klyatskaya, S.; Mascaros, J. R. G.; Bogani, L.; Hennrich, F.; Kappes, M.; Wernsdorfer, W.; Ruben, M.; J. Am. Chem. Soc. 2009, 131, 15143.

http://dx.doi.org/10.1021/ja906165e

PMid:19799421 
283. Urdampilleta, M.; Klyatskaya, S.; Cleuziou, J-P.; Ruben, M.; Wernsdorfer, W.; Nature Materials 2011, 10, 502. http://dx.doi.org/10.1038/nmat3050

PMid:21685902

\section{Authors' Biographies}

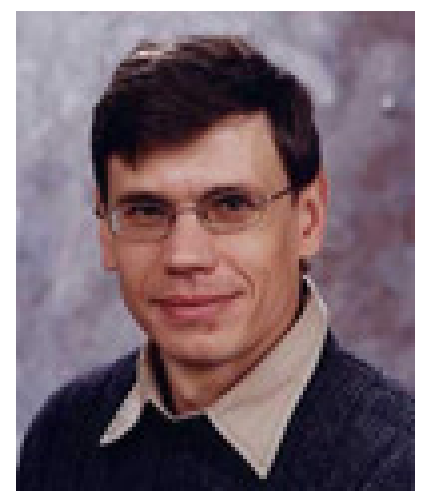

Victor N. Nemykin was born in 1968, received his B.S./M.S. in organic chemistry from Kiev State University, Kiev, Ukraine, in 1993, and his Ph.D. in inorganic chemistry from the Institute of General and Inorganic Chemistry, Kiev, Ukraine, in 1995. He is currently Professor at the Department of Chemistry and Biochemistry, University of Minnesota Duluth. He has coauthored about 150 publications including several patents and book chapters. His research interests include chemistry of porphyrins and phthalocyanines, bio-inorganic chemistry, computational chemistry and structural chemistry of hypervalent iodine compounds.

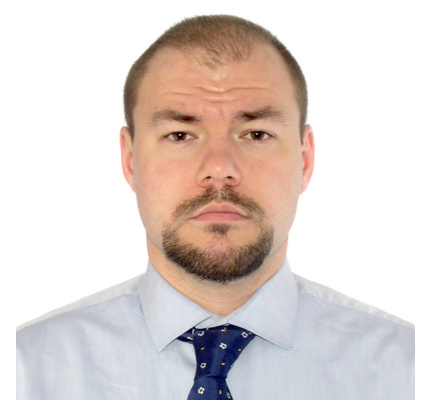

Semyon V. Dudkin was born in 1982, recevied his B.S./M.S. in technology of fine organic synthesis and chemistry of dyes from Mendeleev University of Chemical Technology, Moscow, Russia, in 2005. In 2012, he received his Ph.D. degree in organic chemistry from the same university and Organic Intermediate and Dyes Institute (NIOPIK), Moscow, Russia, under the supervision of Dr. Elena A. Makarova. He is currently Post-Doctoral researcher at the Department of Chemistry and Biochemistry, University of Minnesota Duluth. He has coauthored more than ten publications including three patents and one review. His research 
interests include chemistry of porphyrins, porphyrazines and their hydrogenated derivatives as well as the photodynamic therapy of cancer.

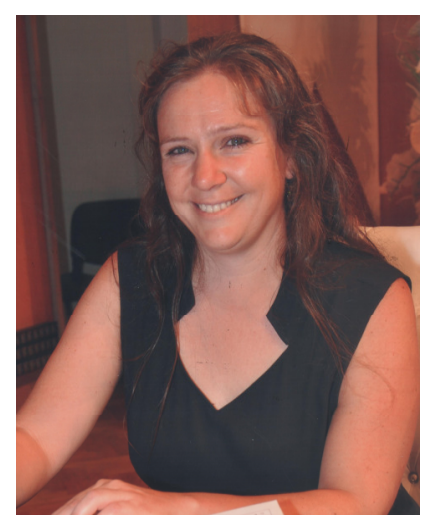

Fabienne Dumoulin was born in 1976, received her European $\mathrm{PhD}$ on the synthesis and selfassemblies of neoglycolipids in 2002, and joined the team of Prof. Dr. Vefa Ahsen at the Gebze Institute of Technology in 2005. She focuses on the rational design and synthesis of photosensitising phthalocyanines for photodynamic therapy. One of her other research interests is the development of new synthetic methods for asymmetric phthalocyanines, as for the first ABAC type phthalocyanine. She authored more than 30 peer-reviewed papers and one book chapter.

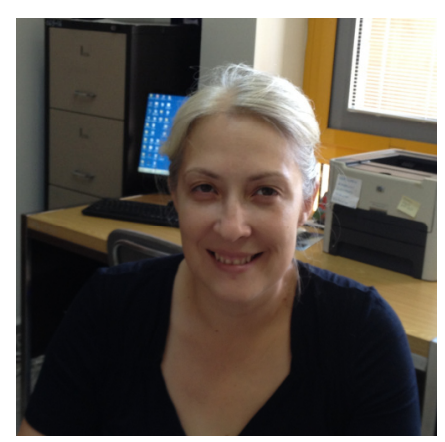

Catherine Hirel received her $\mathrm{PhD}$ degree in Organic Chemistry from the Joseph Fourier University - Grenoble I (France), on the synthesis of enantiopure chiral nitronyl nitroxide free radicals. After a one-year postdoctoral position funded by the European Community's Human Potential Programme (Marie Curie - project POLYCAT), she joined the group of Professor Vefa Ahsen as Assistant Professor at the Gebze Institute of Technology (Turkey). Her research interests are focused on the synthesis of phthalocyanine and porphyrin macrocycles, magnetism as well as the use of microwave energy. 


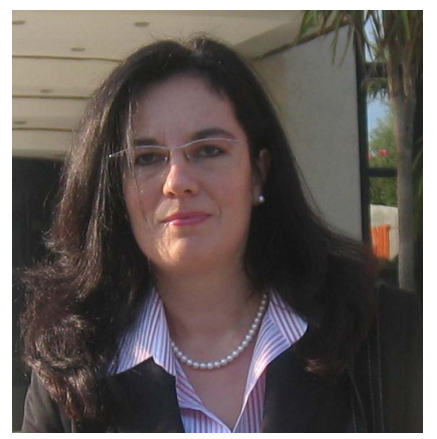

Ayșe Gül Gürek was born in İstanbul, Turkey and graduated in Chemical Engineering from Istanbul Technical University, in 1985. She obtained her M.Sc. in 1994 and her Ph.D. in 1996 from the same university, working on the chemistry of phthalocyanines under the supervision of Prof.Dr. Özer Bekaroğlu. She is currently professor at the Department of Chemistry, Gebze Institute of Technology. She has co-authored more than 100 publications and one book chapter. Her research interests include chemistry of phthalocyanines, structural chemistry of vic-dioxime compounds and their complexes as well as chemical sensors and the photodynamic therapy of cancer.

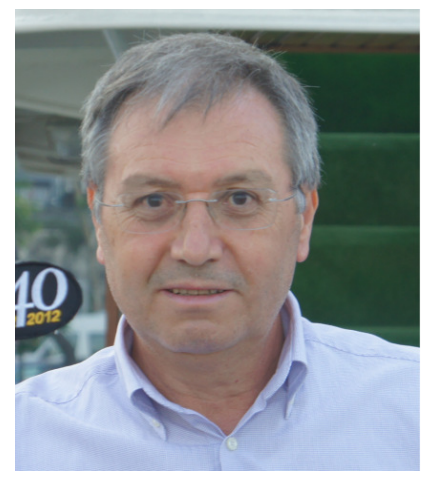

Vefa Ahsen was born in 1953, received his B.S./M.S. in chemical engineering from Istanbul University in 1978, and his Ph.D. in inorganic chemistry from Uludağ University, Bursa, Turkey, in 1984, under the supervision of Prof.Dr. Özer Bekaroğlu. He is currently full professor at the Department of Chemistry of the Gebze Institute of Technology, Turkey. He has coauthored more than 200 publications, edited and co-edited some Journal of Porphyrins and Phthalocyanines issues, and co-edited a book on the role of Photosensitizers in Medicine, Environment, and Security. Focusing on the synthesis of stable ligands such as vic-dioximes, his current research interests lie now mainly on the chemistry of phthalocyanines, with crown ether, aza ether, and thia ether substitution, and on their properties and uses as liquid crystal, semiconductor, gas sensor, as well as photophysical and photochemical agents for photodynamic therapy. He is to be the chairman of the Eight International Conference of Porphyrins and Phthalocyanines, in Istanbul in 2014. 